\title{
Representations of Female Adolescence in the Teen Makeover Film
}

\author{
By Kendra Marston
}

A Thesis Submitted to the Victoria University of Wellington in Fulfilment of the

Requirements for a Degree of Master of Arts in Film

Victoria University of Wellington

2010 


\begin{abstract}
This thesis proposes to analyse the representation of female adolescence in the contemporary teen makeover film. The study will situate this body of films within the context of the current postfeminist age, which I will argue has bred specific fears both of and for the female adolescent. This thesis will examine the construction of the initial wayward makeover protagonist, paying attention to why she needs to be trained in an idealised gender performance that has as its urgent goal the assurance of heteronormativity and 'healthy' sex role power relations. I will also analyse the representation of deviant adolescent female characters in terms of how their particular brand of postfeminist female masquerade masks a power and status-oriented agenda. The behaviour of these characters is shown to impact negatively on the peer group within the film, and is particularly dangerous as it threatens to negate the need for romance.
\end{abstract}




\section{Contents}

$\begin{array}{cc}\text { Abstract } & 1 \\ \text { Acknowledgements } & 3 \\ \text { Introduction } & 4 \\ \text { Chapter One } & 23 \\ \text { Chapter Two } & 62 \\ \text { Chapter Three } & 86 \\ \text { Chapter Four } & 112 \\ \text { Conclusion } & 132 \\ \text { Bibliography } & 143 \\ \text { Filmography } & 153 \\ \text { Television Sources } & 155 \\ \text { Internet Sources } & 157\end{array}$




\section{Acknowledgements}

I would like to acknowledge my supervisor Sean Redmond for the time he put in to helping me with this thesis, as well as for the encouragement, support and advice offered. 


\section{Introduction}

\section{My Moment of Awakening in the Makeover Moment}

While watching The Princess Diaries (Garry Marshall, 2001) for the purpose of this research, I became fascinated by the particular tone of its makeover scene. Just prior to the transformation of the frumpy girl with frizzy hair and glasses, beautician Paolo draws his hairdryer as if preparing for a duel in the Old West. We come to understand that Mia is such an unsuccessful version of femininity that the makeover is sweat-inducing work - the regulation of her appearance to conform to conventional norms of feminine beauty will be a battle. When Paolo first sees Mia he screams at her ugliness, frets, and declares that he is going to be 'busy, busy, busy’ preparing this girl for a state dinner. Throughout the process, he continues to insult the girl with jibes about her appearance, and again there is an allusion to warfare when he commands his henchwomen, Gretchen and Helga, to ‘attack!’ Mia’s ‘bushman’ eyebrows. Gretchen and Helga are sworn to secrecy about the mission, and appear dressed as members of a kind of science fiction secret service - metallic clothing, dark glasses and unwavering stern expressions. They are hard-wired for the makeover business. Although this scene is played for laughs, the masculine connotations of warfare are at odds with the feminine subject of beauty, and with the flamboyant, queer stereotype that frames Paolo's identity. This sense of ambiguity or collision between gender norms is something that I think haunts the makeover moment. What struck me most about this scene however, was the real urgency with which Mia's transformation occurred. The passive Mia, who is too timid, and perhaps too clueless, to speak up about the transformation of her very mode of being, has been initially evaluated rather harshly by an older, wiser, more successful icon of femininity, her grandmother Queen Clarisse, (played by Julie Andrews). Mia is forced to undergo a makeover because it is hoped the ugly duckling will be transformed into a beautiful swan, worthy of the title 'Princess of Genovia.' There isn't a second to spare, the film suggests, so wayward is Mia, so important is it to have her as a perfected image of femininity. 
Elizabeth Ford and Deborah Mitchell in The Makeover in Movies point out that we are not privy to Mia's thoughts as the makeover is carried out. ${ }^{1}$ She is an object in the process. The warrior-like effort needed to transform Mia is shown to be worth it as Queen Clarisse displays pleasure at her new and improved granddaughter. Mia wears perfectly applied makeup, her hair is straight and glossy, and she wears a wide 'beauty queen' smile. The makeover does not stop here for Mia, however. She is taught the correct regal posture, the correct way to dance and meet people. This training, although initially beginning as an urgent battle, a war, leads to a confident and happy adolescent girl who is able to achieve her long awaited dream of a foot popping kiss at a royal ball, where she shows off her newly acquired Princess skills. She has become the perfect embodiment of feminine beauty and heterosexual desire.

When I first decided upon a study of female adolescence in the teen makeover film, I anticipated that much of my time would be spent analysing beautification scenes like the one discussed above. I thought I would be writing about fashion montages, product placement of makeup brands, and the glorification of consumption as a route to happiness and contentment. I expected to be singularly employing Lacanian psychoanalysis for scenes in which made-over female adolescents twirled before a mirror, rapt with excitement and pleasure at the potential of their new sexually desirable bodies. I didn't encounter what I had expected. In films that required the female adolescent to undergo a complete physical transformation (The Princess Diaries and She's All That, Robert Iscove, 1999) there did not seem to be any consumption of clothes and beauty products involved. Neither girl was told to go into a shop and spend wildly as Julia Roberts was asked to do in Pretty Woman (Garry Marshall, 1990). In fact, there seemed to be a profound distrust of the consumption choices they might make. For these makeovers, the girl has to sit in a room while those who 'know better' take full

\footnotetext{
${ }^{1}$ Ford, Elizabeth and Mitchell, Deborah. The Makeover in Movies. (North Carolina: McFarland and Company Inc, 2004). Pg, 26.
} 
control of her transformation. I also noted the fact that the girl's evaluation of her made-over self was far less important than the final judgement of the orchestrator of the look and/or male peers. As I watched Paolo the beautician in The Princess Diaries draw his hairdryer as if it were a gun, I couldn't help but feel that this could be read as more than a reference to the fact that the filmic characters believed Mia to be so physically hideous that it would take a supreme battle to turn her into a conventional beauty. The idea that the makeover was being presented as a kind of comedic duel interested me, although certainly Mia was a rather passive and submissive sparring partner. The makeover was not presented as a fun chance for somebody decreed as unfortunate to try on a new identity. Rather the makeover was fundamental, urgent, and necessary in order to shape the protagonist's destiny toward romance and contentment. This was as true of films that concentrated on making over social behaviour (10 Things I Hate About You, Gil Junger, 1999) or those that focused on a particular Cinderella moment ( $A$ Cinderella Story, Mark Rosman, 2004) as it was of films that proudly presented a contrasting pre and post makeover female body. Although the films were at pains to point out that the makeover was a just reward for the overlooked girl, who without knowing it was unhappy in herself, the fact that it occurred with such brutality, and was only later seen as a loving gesture, indicated that something more was at stake than the happiness of one individual character. After all, in every battle there are stakes.

Noting that most makeover protagonists seemed to share certain 'hidden' valuable and nurturing character traits that only the audience is initially privy to, I began to wonder whether makeover films were as much about uncovering and unearthing as they were about making over. I saw the teen makeover film protagonist not only as a Cinderella, but as a Sleeping Beauty, lying dormant in wait for Prince Charming. The teen makeover protagonist was a diamond in the rough - sweet, passive, with a nurturing inner light that represented rare values in spaces where status, money and greed reigned. These films I decided were not just a battle to regulate feminine appearance, but a battle to preserve a dying femininity, here 
being hidden behind an abject appearance and wayward activities. The battle, the war, was not just about fighting to save an individual soul, but a type of soul, a feminine soul in danger of not being of use, of not being channelled into reproduction. This soul was lost and languishing, having been whittled into near non-existence by ‘outside’ influences.

\section{A Thesis at War}

In this thesis, the makeover film will be read as a battle for control of femininity; a battle for a certain type of femininity to be realised and publicly validated. I believe the battle that takes place in the narrative of the makeover film can be read as a way of negotiating social debate over the corruptible and corrupting adolescent girl. Because of the fact that I see the teen makeover film as a battle for a certain type of femininity to win through, I will not be concerned only with changes in the physical appearance of the adolescent. The makeover scene and its implications regarding the regulation of the female body has been extensively researched in relation to cinema and television in, amongst others, The Makeover in Movies by Ford and Mitchell (McFarland and Company, 2004), Makeover Television: Realities Remodelled edited by Dana Heller (I.B Tauris \& Co, 2007), and The Great American Makeover: Television, History, Nation, also edited by Dana Heller (Palgrave MacMillan, 2006). Makeover narratives have been referenced in wider studies of postfeminism, such as Angela McRobbie's The Aftermath of Feminism: Gender, Culture and Social Change (SAGE Publications, 2009) and Diane Negra's What A Girl Wants? Fantasizing the Reclamation of Self in Postfeminism (Routledge, 2009). What I am interested in, however, is how the makeover narrative works specifically in stories about adolescent characters in postfeminist times, rather than women more generally. I have concentrated not so much on the makeover scene, which I feel has been adequately researched elsewhere, but on why certain adolescent girls are chosen for this process and how the romance resulting from the transformation works to validate it. I want to look particularly at how the performance of gender is promoted as an empowering experience in these films, while also being necessary training for the protagonist, 
who is seemingly doomed to a life of invisibility. Of course, given my analysis relies on the idea that there is a battle for a certain type of femininity, this implies there are two warring sides.

A key difference I have noted between teen makeover films and other makeover movies featuring older central characters is the abundance of female antagonists in the former. Many studies of the makeover focus solely on the person that is made over. However, the female protagonist is not the only female adolescent of importance in this story. While I will be analysing not only the central adolescent's place in her broken family, the initial presentation of her as wayward and unintentionally threatening, how romance as a result of the makeover situates her differently, I will also focus on how she is constructed as a unique treasure in contrast to deviant female adolescents. I will argue that these teen makeover villains can be read as potentially threatening products of the postfeminist age that encourages younger and younger girls to consume and to sexualise their bodies in order to empower themselves. The teen makeover protagonist is made-over to improve her chances of romance, this is true, but she also serves to put romance back on the map as important for the future of a society that may be endangered by a perceived female obsession with visibility and status that does not necessarily bode well for the stable, reproductive family unit. These teen makeover films are a lesson in life, as I shall introduce below

\section{The Teen Makeover Film in History and Context}

As was characteristic of many ancient fairytales and myths, the teen makeover film takes the form of a lesson in socialisation or ideal citizenry for its characters. However, in accordance with current fears for the morals of the female adolescent, these films deal with concerns arising out of postfeminism and the popular images of femininity available nowadays to teenage consumers - images which may threaten traditional sex and gender roles and create an environment hostile to the nuclear family. In keeping with postfeminism, the makeover film preaches that empowerment arises out of gender intelligibility and an association with the body 
over mind, but this must also be matched with an endangered inner fragile soul that has to be protected by patriarchy. The idea of a nurturing and gentle soul has often been utilised when depicting a woman to be cherished and elevated above the 'masses', whether this is evident in the characterisation of the classic fairytale princess, in female characters in the classic makeover film, or in the morally deserving female contestants on reality makeover shows. ${ }^{2}$

In the teen makeover film it may be the case that the person who either transforms the girl into coveted object or valuates her new idealised form, also becomes her love interest. In many cases, the love interest is the creator of the look, sculpting and moulding his ideal partner in a manner reminiscent of Ovid's 'Pygmalion,' so that she will become revered as his great work of art. This solidifies his status as master of all other living things - anything can be bent to his all-powerful will, as it is he who sets the laws. It is through a fairytale romance, 'true love,' that the teen protagonist reaches the top of the social order of the school, and may gain a regal position over her new impressionable subjects.

The teen makeover film civilises its protagonist, outlining the rules and regulations of gender performance in an age where girls are invited to consume to gain empowerment. The teen makeover film does extend this invitation, but in a limited capacity which represents female consumption as taking place under a strict policing gaze that ensures the new look does not come at the expense of traditionally feminine virtues or in the way of romanticised, sanitised love. The made-over girl dancing in a prom gown with her Prince is reminiscent of many a fairytale scene, popularly utilised in film by Disney, where the dance symbolises the 'true expression of love, ${ }^{3}$ the Princess iconography indicating one form of idealised femininity for young girls who grew up with tales of Snow White,

\footnotetext{
${ }^{2}$ Guy Redden discusses the fact that the television makeover subject is often morally deserving in 'Makeover Morality and Consumer Culture.' Makeover Television: Realities Remodelled. Ed: Dana Heller. (London and New York: I.B Tauris \& Co Ltd, 2007). Pg. 158.

${ }^{3}$ Bell, Elizabeth. 'Somatexts at the Disney Shop.' In From Mouse to Mermaid: The Politics of Film, Gender and Culture. Eds: Elizabeth Bell, Lynda Haas and Laura Sells. (Bloomington and Indianapolis: Indiana University Press, 1995).Pg. 113.
} 
Cinderella and Sleeping Beauty. Through borrowing tropes from fairytale and Pygmalion narratives, the makeover film presents a tale full of recognisable elements to the audience, playing with nostalgic forms of gender relations in contrast to manipulated images of current threats regarding female consumption.

\section{The Makeover as Fairytale}

Through plots that tend to focus on the plight of the overlooked individual, who is then commonly recognised by a social superior and put on display as an example for others to follow, the teen makeover film is strongly reminiscent of well known fairytales like 'Cinderella'. However, in its focus on the civilising of the protagonist, the makeover film is similar not only in plot to the fairytale, but in ideology also. In 'When Dreams Come True: Classical Fairy Tales and their Tradition,’ Jack Zipes explains that traditionally fairytales were told to create communal bonds and progressed to be told to provide hope in a seemingly despairing world. ${ }^{4}$ The wonder tale gave the protagonist an opportunity to change his or her life, to become a King, a Queen or a 'lord of destiny.' To break an evil doer's spell was to be an agent in emancipating oneself. ${ }^{5}$ Metamorphosis has always been a key theme in the fairytale, and in 'Psyche and Cupid' by Apuleius there marked a focus on the civilisation of the protagonist, who had to learn to respect and adhere to certain societal laws in order to continue his progression, and ultimately the progression of the world toward bliss and happiness. ${ }^{6}$ Fairytales were initially told to adults, and it was not until the theologian and Archbishop of Cambrai, Fenelon, wrote down several fairytales for children in order to make lessons more enjoyable that they became acceptable for this audience. These stories were printed in 1730 and had to be crafted in order to indoctrinate children - training them in gender relations and classed behaviour in accordance with the civilising function of these tales. ${ }^{7}$ Later, Madame Marie Catherine D’Aulnoy’s fairytales, which were published in the 1790s, focused in

\footnotetext{
${ }^{4}$ Zipes, Jack. When Dreams Come True: Classical Fairy Tales and their Tradition. (New York and London: Routledge, 1999). Pg 1.

${ }^{5}$ Ibid. p. 7.

${ }^{6}$ Ibid. p. 8.

${ }^{7}$ Ibid. p. 15.
} 
large part on the notion of tendresse - 'true and natural feelings between a man and a woman, whose nobility would depend on their manners and the ways in which they upheld standards of civility in defending their love. ${ }^{8}$

It is evident that many of these historic inflections in the fairytale are still in place in the modern day makeover film. While what is perceived as a societal threat changes over time, and issues and themes evident in the fairytale may not be the same as those articulated in the teen makeover film, the framework of the story which is used to combat these threats in the narrative is markedly similar. The makeover, or the 'metamorphosis,' of the teen protagonist in film provides hope for an older model of femininity, a femininity which is in fact commonly similar to the fairytale model of the idealised girl. This older model provides a contrast to the spate of postfeminist-influenced teen girl consumer characters who treat the males around them as just another commodity. In the teen makeover film, heterosexual romance is all-powerful; a similar message to that preached in fairytales.

The fairytale opportunity to change one's life course, to become a King, a Queen or a 'lord of destiny,' is manifested in the narrative as the protagonist is elevated up the social order by putting her body on display primarily for the love interest or because it has become her duty to do so. Princesses and Queens are held up as the ideal models of femininity in the fairytale, and in the subsequent makeover film, as these figures perhaps embody the most constricted mode of female bodily performance. The regal woman, who lives her life in the public eye, is subject to the gaze of her public, her disciplined body providing an idealised form that others are measured against. She is restricted in her space and in her movement - she must be the epitome of grace. The displayed body in the teen makeover film has often been carefully manufactured by a male, or godmother figure, to conform to notions of what it means to be a 'lady' in contrast to the deviant characters in the narrative. The teen protagonist, as in The Princess Diaries, may be taught to walk,

${ }^{8}$ Ibid. p. 11. 
talk, and eat like a female of the upper classes, like a fairytale princess. She may be taught to dress in a manner the male character sees, or will see, as befitting of someone who is not brazen in their sexuality (She's All That). ${ }^{9}$ In the teen makeover film, girls who overtly fetishise their bodies without being 'in love,' i.e. in the possession of a male character, are the villains of the piece. The fact that they display a sexual agency marks them negatively in contrast to the (commonly) virginal protagonist, who is often sanctified in the film's conclusion in her submission to the worshipped hero.

Often the good girl virgin may be named Prom Queen or be given a crown by some other means as evidence of her new regal status. The made-over teen Princess becomes a figurehead in the space of the school, particularly if she is paired with an idealised male. She is in the process of having patriarchal standards of feminine beauty internalised and naturalised in order to perform a femininity of class, which is an inhibited controlled femininity that is always held up for public scrutiny, unable to transgress without punishment. The degree to which she must replicate this version of the idealised feminine however does differ between texts. She replaces the bodies of the teen antagonists as the ideal, they in opposition being tarnished, of low moral worth and of a low social class. Class it seems can be performed in accordance with gender. Despite the fact that the antagonists have money, they do not have 'class.'

The fairytale historically presented the protagonist with a chance to become lord of his or her own destiny, but in the makeover film, although the female is presented as being empowered, it is the male character that is often presented as instigating her new future by manipulating her looks and body. If the male does not undertake this task himself, a fairy godmother with an investment in patriarchal structures marks the female as 'deserving' of happiness, as happens in The Princess Diaries. When one thinks of the tradition of fairytales, it is not

\footnotetext{
${ }^{9}$ Rachel Moseley explores how overt sexuality is seen as incompatible with perceptions of higher class in Growing Up With Audrey Hepburn. (Manchester and New York: Manchester University Press, 2002). Pg 112.
} 
necessarily names like D’Aulnoy or Apuleius that come to mind, however. Instead, it is perhaps the more recent Disney variations on these old stories that have the most influence on modern perceptions of the fairytale. These versions have a particular emphasis on containing their heroines within rigid patriarchal power structures, and do so through the characterisation of the protagonist and through particular methods in the narrative.

\section{The Disneyfication of the Fairy Tale}

Due to the popularity of the globalised Disney brand, generation after generation of people are growing up with modifications of old fairy and folk tales infused with elements synonymous with the company’s image. The teen makeover film, in narratives strongly dependent on audience recognition of fairytale tropes, are indebted to Disney's constructions of the feminine, particularly that of Cinderella, as these images are the most circulated fairytale femininities in Western culture. These images of the feminine are mediated through a male discourse that promises an idealised heterosexual romance for girls who adhere to fashionable codes of female beauty and who harbour virtues pre-figuring the nurturing mother who places the good of others over herself. ${ }^{10}$ It is necessary to note that some teen makeover films are made by the Disney studio (The Princess Diaries) or the films may feature stars closely associated with the brand (Hilary Duff in A Cinderella Story and Lindsay Lohan in Mean Girls, Mark Waters, 2004). It is important here to go into some depth about the traditional representation of the female adolescent in the Disney classic due to these influences on and connections with the teen makeover film.

Although Disney's animated Cinderella was released in 1950, repeated special edition releases of the VHS and now DVD ensure the tale reaches new audiences as the years go by. While Disney borrows forms of fairytales from versions put forth by the likes of Charles Perrault, the Brothers Grimm, and Hans Christian

${ }^{10}$ Valerie Walkerdine discusses the model of the good hard-working girl as prefiguring the mother figure in Daddy's Girl: Young Girls and Popular Culture. (Massachusetts: Harvard University Press, 1997). Pg 169. 
Andersen, these tales must be adapted so that the resulting product is recognisable as part of the Disney formula. Jack Zipes writes that while there are many sophisticated forms of fairytales circulating in modern society that aid readers in focusing on key social problems, the classical fairytales that revolve around sexist messages and conservative notions of social behaviour continue to be money makers. These tend to take the form of films or plays rather than reading material. ${ }^{11}$ Elizabeth Bell points out that with the logo Walt Disney Pictures, Disney has inscribed his name and ownership on folk stories, creating indelible images of the feminine. ${ }^{12}$ She cites a survey undertaken by Kay Stone in 1975 on British and American girls that found that the most vivid recollections of fairytale femininities were Disney’s versions of Snow White, Cinderella and Sleeping Beauty. ${ }^{13}$ Disney made telling modifications to fairytales that aimed to stabilise binary gender relations of active male and passive female, while punishing wicked women who deviated from their maternal responsibilities and plotted to create matriarchal societies that would plunge the world into evil chaos. It is important to note here that even though in more recent times, Disney heroines do have more of a voice, their independent streak is still nullified through marriage, which seems to be the answer to all their woes as long as the partnership is right. Even Disney's more progressive heroines are contained through means that solidify their place in the fairytale - for instance although Belle in Beauty and the Beast (Gary Trousdale and Kirk Wise, 1991) is an avid reader, she predominantly reads fairy stories where a young girl meets and falls in love with Prince Charming. In 'Breaking the Disney Spell,' Zipes points out that Disney changed the way Snow White was awakened from her coffin from a dwarf tripping over while carrying her to the all-powerful kiss of true love. ${ }^{14}$ Zipes believes Disney celebrated the

\footnotetext{
${ }^{11}$ Zipes, Jack. When Dreams Come True: Classical Fairy Tales and their Tradition. (New York and London: Routledge, 1999). Pg 26.

${ }^{12}$ Bell, Elizabeth. 'Somatexts at the Disney Shop.' In From Mouse to Mermaid: The Politics of Film, Gender and Culture. Eds: Elizabeth Bell, Lynda Haas and Laura Sells. (Bloomington and Indianapolis: Indiana University Press, 1995). Pg 108.

${ }^{13}$ Ibid. p. 108.

${ }^{14}$ Zipes, Jack. 'Breaking the Disney Spell.' In From Mouse to Mermaid: The Politics of Film, Gender and Culture. Eds: Elizabeth Bell, Lynda Haas and Laura Sells. (Bloomington and Indianapolis: Indiana University Press, 1995). Pg 36.
} 
domestication of women, and aimed to 'clean up' the world in accordance with his own ideologies by crafting pre-ordained destinies for his characters based on his own beliefs. ${ }^{15}$ He follows Sandra Gilbert and Susan Gubar's analysis in The Madwoman in the Attic in emphasising that Disney's heroines are framed through a male discourse that pits woman against woman in competition for male approval, which in Snow White and the Seven Dwarves takes the form of the magic mirror with its judgmental gaze. Women cannot chart their own lives without male manipulation and intervention. ${ }^{16}$ It is surely no accident that the Cinderella tale Disney's version is most indebted to is one with a particularly passive heroine. Elizabeth Ford and Deborah Mitchell note that some Cinderella tales did feature feisty and active heroines but these are not the versions American culture chooses to retell. ${ }^{17}$ Perrault's 'Cendrillon ou la petite pantoufle de verre,' with the socialising aim of conditioning seventeenth century maidens for the hardships of arranged marriages, places emphasis on Cinderella's sweetness and placid obedience. $^{18}$

In the Perrault/Disney Cinderella story, Prince Charming is the reward for the morally deserving girl who undergoes a physical transformation to reveal the outer beauty that should rightfully match her inner beauty. Her soul is a diamond hidden amidst the 'rough,' which is constituted of a set of bodily signifiers that render her a humble servant girl in the eyes of those who come across her. Cinderella's passive, nurturing and obedient nature is in danger of being wasted by not being channelled into reproduction, unless she can be made visible to an icon of patriarchy in a visual language he understands. Cinderella's beautiful, white, flowing ball gown, created by a fairy godmother who looks after the girl in the maternal manner that she has been missing, indicates her pure, clean, uncorrupted femininity. The whiteness of the gown prefigures the bridal gown,

\footnotetext{
${ }^{15}$ Ibid. p. 38.

${ }^{16}$ Ibid. p. 36.

${ }^{17}$ Ford, Elizabeth and Mitchell Deborah. The Makeover in Movies. (North Carolina: McFarland and Company, 2004). Pg 31.

${ }^{18}$ Ibid. p. 31.
} 
symbolising Cinderella's virginity and her whole untouched form. ${ }^{19}$ Her sexually untouched whole body parallels with her whole uncorrupted submissive femininity, which marks her as an object of wonder given the societal threats to idealised gender relations. Cinderella is allowed to marry her Prince, become an emblem of regal womanhood, and presumably pass her idealised traits down the royal blood line.

In outlining here the typical representation of the female protagonist in the Disney text, I aim to draw attention to the similarities between these representations and the common construction of the protagonist in the teen makeover film. As in the Disney animated film, the makeover tale aims to stabilise gender relations by sanctifying a certain type of female, whose character lies in contrast to the 'wicked woman.' While the teen makeover protagonist may not be as placid and sweet as Disney’s Cinderella, she is still markedly more passive, and certainly more nurturing, than her deviant counterpart. As in the Disney text, females in the teen makeover film are in competition for male recognition and approval. In the majority of teen makeover films, it is up to a male character to chart the romantic destiny of the designated idealised female.

\section{The Pygmalion Myth}

Elements of the Cinderella story are clearly evident in most teen makeover films, which have a similar ideological drive to the fairytale despite manipulating various elements of the story and characters in order to adapt them more adequately to a modern setting. Another tale which is heavily represented in the teen makeover film, particularly in She's All That, is Ovid’s 'Pygmalion,' originally a classical myth in which the character of the title carves himself the ideal woman out of ivory, Galatea, who is then brought to life by the goddess Venus. Kathryn Fraser in explaining the Pygmalion narrative in relation to makeover television, describes the male character as 'something of a misogynist'

\footnotetext{
${ }^{19}$ Richard Dyer discusses the cult of virginity and its connotations with cleanliness and wholeness in
} association with whiteness in White. (Oxon and New York: Routledge, 1997), Pg 77. 
who creates his ideal woman after living a life of bachelorhood due to his revolt at the 'faults nature has implanted in the female sex. ${ }^{20}$ She points out that Galatea conforms to classical ideas of femininity in that she is 'passive, immobile and essentially decorative. ${ }^{21}$ Galatea exists for male desire and reproduction and thus is not a desiring subject. In George Bernard Shaw’s version however, Galatea becomes aware of her objectified status and experiences feelings of resentment. ${ }^{22}$ Shaw places a heavy emphasis on class in his tale, with Henry Higgins (Pygmalion) taking a colonial approach to teaching Eliza (Galatea) how to speak and dress 'properly' in order to have her pass as a Duchess. ${ }^{23}$ Fraser links Shaw's perception of a crisis in class to a crisis in femininity, noting that Eliza cannot conform to ideals of correct femininity in large part due to her class. ${ }^{24}$ We are told she is unattractive, presumably because she does not conform to these ideals. She is also compared by Shaw to real ladies as being 'dirty,' which invites a reading of the association between higher forms of whiteness and the upper classes. The transformation of Eliza importantly forces her to shift spheres so that she moves to a space where she now 'belongs' due to the increased social value of her body. She is moved to a controlled space under the domination of male authority through her transformation to a bodily spectacle which solicits male desire. ${ }^{25}$ The woman on her own, either independent or undefined by male desire, results in a problematic which constitutes the before phase of the makeover candidate. ${ }^{26}$

An important aspect of the Pygmalion story, present in the Ovid version, are the characters of the Propoetides, or the fallen women, who Pygmalion expresses disgust with, prompting his creation of the ivory statue. Paula James explains that the Propoetides, women of Cyprus, turned to prostitution after denying the

20 'Fraser, Kathryn. 'Now I am ready to tell how bodies are changed into different bodies... Ovid, The Metamorphoses.' In Makeover Television: Realities Remodelled. Ed: Dana Heller. (London and New York: I.B Tauris \& Co Ltd, 2007). Pg 186.

${ }^{21}$ Ibid. p. 185.

${ }^{22}$ Ibid. p. 186.

${ }^{23}$ Ibid. p. 186.

${ }^{24}$ Ibid. p. 187.

${ }^{25}$ Ibid. p. 188.

${ }^{26}$ Ibid. p. 185. 
existence of Venus. The Propoetides later became statues 'as part of the dehumanising process their metamorphosis into whores had set in motion,' although what they were before they became prostitutes is a mystery. ${ }^{27}$ James points to the contradictions within the ivory maiden, who is to be treated by Pygmalion as both mistress and virgin; 'Pygmalion demonstrates that he wants his statue to be aroused by and to respond like a mistress to his attentions, but the reason for her creation from ivory was to preserve her from such female characteristics. ${ }^{28}$

The villainous characters of the teen makeover film are clearly reminiscent of the Propoetides in Pygmalion. In films such as She's All That, A Cinderella Story and Mean Girls, the teen male hero often falls for the initially invisible 'good girl' as a result of growing disgust at the hyper-feminine girls he has previously surrounded himself with, and who see their sexualised bodies as markers of their higher value within the social order. Like the Propoetides, what these characters were before their current status as fallen women is often unclear, although the films appear to place blame on consumption tied in with girl power promises, an element of the films that I will examine in Chapter One. Despite traditionally male character traits including their sexually forward behaviour, these characters appear to be reassuringly hyper-feminine. However, their heterosexual desire comes into question, as this desire seems to be channelled towards fame, visibility and control rather than romance. Consumption, it would appear, has hijacked authentic desire.

The Galatea figure, who in the teen makeover film the male may choose to mould to fit his ideal conception of the feminine, does not start off as a blank slate or 'ivory statue.' As will be examined in Chapter Two, she is often presented as a confused cross-gendered girl from a single parent family - the absence of a parent hindering her natural development. Most often, this character will have an inner feminine light common to the Cinderella figure, although she may also be

\footnotetext{
${ }^{27}$ James, Paula. 'She’s All That: Ovid's Ivory Statue and the Legacy of Pygmalion on Film.' In Classical Bulletin 79.1 (2003). Pg 72.

${ }^{28}$ Ibid. p. 77.
} 
entrapped by class as is Eliza Doolittle, giving the love interest a chance to transform her into a regal Princess icon. The rules and regulations of envied femininity are often presented as a gift of opportunity in the form of a makeover. These rules and regulations, indicative of a patriarchal construction of the feminine, have to be adopted by the candidate in order to create a docile conforming body. While the Galateas of the teen makeover film may question the makeover at certain points in the story after it has been conducted, this is seen as a momentary point of weakness, while also giving the male a chance to cement his active status as he looks after the female in her time of extreme vulnerability and fragility. The teen makeover film responds to current fears for the adolescent, but does so through a language which is recognisable to its viewers due to its past deployment in fairytale and myth.

The films I have chosen to analyse for this study range from the years 1999 2008, although most were made in the earlier years of this time bracket. I have chosen to look at teen makeover films made within these years because I believe they best articulate the battle for control of an adolescent femininity under threat due to the influences of aspects of postfeminist discourse. It is therefore important that I study films made at a time when chick postfeminism, which I will discuss in detail in Chapter One, was at its height of popularity. I have chosen to concentrate more heavily on films which have a central protagonist undergo physical and behavioural changes in order to be socially accepted, as it is these films which provide the most interesting contrast between the main character and the deviant female adolescents that seek to thwart her progress. Films that fulfil this criteria include She's All That, The Princess Diaries, 10 Things I Hate About You and A Cinderella Story. However, I will also include a couple of films that mainly focus on these deviant characters in the relevant chapter, Mean Girls and Wild Child (Nick Moore 2008) as these texts provide interesting scope for a deeper analysis of these often secondary characters. 


\section{Thesis Structure}

The main body of my thesis is divided into four chapters. Each will contribute to my overall reading of the teen makeover film as a battle for a lost feminine ideal, and for control of an adolescent femininity that can so easily be led down a wayward path that threatens patriarchy and heterosexual normativity.

\section{Chapter One: Postfeminism, Popular Culture and Fears for Female}

\section{Adolescence}

This chapter will introduce the theoretical and contextual material that will shape and inform my thesis. I will discuss Judith Butler's work on gender performance and introduce the idea of the Foucauldian gaze in terms of how it has been applied to female body experience. Of utmost importance here is the theory that gender must be performed in a certain way to ensure heteronormativity and the hierarchical sex and gender order. This chapter will also situate the teen makeover film as a product of the times of postfeminism. I will discuss what I take postfeminism to mean, and the representations that have arisen out of this time for young girls. Finally, this chapter will look at societal fears of the adolescent girl; ones that arise from the perception that they are being targeted by a postfeminist consumer culture. I will situate the teen makeover film within the context of this debate.

\section{Chapter Two: The Female Adolescent in Space and as Sign}

In this chapter, I will analyse the initial presentation of the central female adolescent (the ugly duckling) as wayward, looking at how she manifests a gender borderlessness that is in need of rectification through the transformation of her body, and the reinscription of her relationship to space. Nevertheless, I will illustrate that despite the fact that these girls do not outwardly conform to the rules of femininity within patriarchal culture, they are imagined to have a valuable inner feminine 'core' that must be imminently brought to the surface. I will show that 
the central female protagonist is unable to perform femininity due to her upbringing in a single parent family, a crisis the film suggests needs fixing.

\section{Chapter Three: Deviant Teens}

In this chapter I will study the construction of the deviant female adolescents in the makeover film. I will illustrate that despite the fact that these characters are hyper-feminine, they are presented as threatening due to their postfeminist traits. They wear a mask of femininity that conceals their true desires. In this chapter I will also analyse how teen males are presented as being in a dependent position in relation to these girls, and how these films aim to 'correct' the gender power dynamic through rejecting these relationships. The deviant female teen is often punished, the ugly duckling turns into a swan, and the hero finds his ideal match.

\section{Chapter Four: The Last Kiss and the Romantic Resolution}

My final chapter will look at the romantic resolution that the teen makeover film offers through an analysis of the final all-powerful kiss. I will examine how the kiss acts as an assurance and validation of the central partnership, while paying particular attention to the fact that the kiss comes about as the result of an interruption of language. I will show how the film validates a redirection of female desire to serve patriarchal interests by analysing the final speech act of the makeover protagonist. It is this speech act that indicates the central female has internalised the scrutinising gaze that initially found her to be an unsuitable version of femininity.

\section{Conclusion}

I will conclude this thesis by suggesting that the teen makeover film elevates a type of femininity that is in danger of being lost due to a consumption-oriented postfeminist culture that teens are said to exist in. This traditional version of idealised femininity is embedded in a female body that cannot invite desire at the outer layers of her person. The makeover works to train the protagonist in the performance of femininity, so that she can become a recognisable object of desire 
to a male love interest. Relationships built on a flawed sex and gender order are rejected in favour of the central romance, which is whole, glorified and true. I will also situate the teen makeover film within a wider cultural context, studying the current obsession with making over and becoming with particular reference to makeover reality television. 


\section{Chapter One: Postfeminism, Popular Culture and Fears for Female Adolescence}

With its gift of idealised femininity and subsequent visibility, the teen makeover film is essentially a coming-of-age tale that, like the fables this story is indebted to, transforms the pure but wayward teen protagonist into the embodiment of all that good girls are supposed to desire to be. The makeover in these films transforms ugly duckling into swan, and is coded as a lesson in the rules of gender performance for females; a disciplining of the body that these characters are encouraged to take up in order to eventually partake in a nuclear family that serves the interests of society. But femininity itself has become a battleground of contradictions in a postfeminist age that seeks to, perhaps impossibly, reconcile feminism and a femininity constructed by patriarchy. The teen makeover film wrestles with these tensions and contradictions, as I will now go on to suggest.

These films articulate a series of worries, questions and possible solutions to female performance in a postfeminist age. The villains of the piece are clearly robbed from representations of chick postfeminists and girl power icons in today's popular culture texts, and yet these films are aiming to make money from the same consumers who relish these images. Yvonne Tasker and Diane Negra note that the term postfeminist indicates that feminism is a movement belonging to the past, while pointing out that aspects of feminism have been commodified in the new figure of the 'empowered' female consumer. ${ }^{29}$ Postfeminism is focused on the affluent individual, and promotes consumption as a strategy to cure dissatisfaction, which the writers note confuses individualism with self interest. ${ }^{30}$ Tasker and Negra point out that popular culture in the UK and the US has since the 1990s been characterised by a heightened address to female consumers; 'The construction of women as both subjects and consumers or perhaps as subjects only to the extent that we are willing and able to consume is one of the contradictions

\footnotetext{
${ }^{29}$ Negra, Diane and Tasker, Yvonne. Interrogating Postfeminism: Gender and the Politics of Popular Culture. (USA: Duke University Press, 2007). Pg 2.

${ }^{30}$ Ibid. p. 2.
} 
at the core of postfeminist culture. ${ }^{31}$ Rebecca Munford notes that most feminists see the construction and marketing of girl power to girls and young women as resultant of the popularity of postfeminism, a backlash product. ${ }^{32}$ She describes it as a popular philosophy which proclaims to celebrate modes of femininity, citing examples which include makeup, high heels, and Barbie dolls. In this manner, femininity becomes not oppositional to feminism, but 'central to a politics of agency, confidence and resistance. ${ }^{33}$ However, Munford points to the questionable claims of girl power as a political update of feminism in noting that it is male-owned companies that capture the slogan, robbing it of any real political potential, in ploys to market groups and merchandise to young female consumers. ${ }^{34}$ The Spice Girls, the group which brought girl power to the attention of the mainstream, are cited here as an example of how the feminist slogan can be commodified and contained, with Munford noting that the group is split into five marketable categories of femininity - Baby, Posh, Sporty, Scary and Ginger. ${ }^{35}$ Jessica K Taft has also referred to the Spice Girls in her discussion of girl power in order to demonstrate that the so-called popular culture alternative to feminism does not indicate an aim for social or political change. Girl power needs to be marketable and therefore is shown to be 'softer, sexier and less active than feminism,' giving feminism a 'kick up the arse' (to use Spice Girls terminology) by emphasising beauty and appearance. ${ }^{36}$ Postfeminism, however, is a landscape of textual play on Madonna/Whore gender constructs, where manufactured sisterhoods claim men are disposable while appearing overtly sexualised for their gaze. The teen makeover film seems to ask questions as to whether it is possible that female constructs may have the capacity to subvert men's own domination by the very means they were rendered passive in the first place. While this capacity is

\footnotetext{
${ }^{31}$ Ibid. p. 8.

${ }^{32}$ Munford, Rebecca. 'Wake Up and Smell the Lipgloss: Gender, Generation and the (A)Politics of Girl Power.' In Third Wave Feminism: A Critical Exploration. Eds. Stacy Gillis, Gillian Howie, Rebecca Munford. (New York: Palgrave MacMillan, 2007). Pg 267.

${ }^{33}$ Ibid. p. 268.

${ }^{34}$ Ibid. p. 274.

${ }^{35}$ Ibid. p. 274.

${ }^{36}$ Taft, Jessica K. 'Girl Power Politics: Pop Culture Barriers and Organizational Resistance.' All About the Girl: Culture, Power and Identity. Ed. Anita Harris. (New York and Oxon: Routledge, 2004). Pg 71.
} 
highly debatable, the teen makeover film appears to re-invoke the romantic fable, promising recognition and visibility to its young fame-conscious consumers through re-securing the terms of heterosexuality and the hierarchical sex and gender order. In this chapter I will first introduce my overarching theoretical framework for my whole thesis, while also introducing the context for these films, which aim to address postfeminist promises, postfeminist idols and fears for the adolescent arising out of these times.

\section{Theoretical Overview}

In 'Performative Acts and Gender Constitution: An Essay in Phenomenology and Feminist Theory,' Judith Butler, in explaining her theories of gender as a series of repeated and stylised acts, utilises the work of phenomenologist Maurice MerleauPonty to demonstrate that the lived body is an historical idea. ${ }^{37}$ As Butler reasons, 'one is not simply a body, but in some very key sense, one does one's body and indeed, one does one's body differently from one's contemporaries and from one's embodied predecessors and successors as well. ${ }^{, 38}$ It is the theory that gender performance is a series of acts which are constantly subject to change and yet are always serving a social policy of gender regulation and control ${ }^{39}$ that provides the focus for this thesis. There will be a central emphasis on postfeminism in this chapter, as well as what the adolescent has come to signify at a time when they are supposed to be focused on exceptional career paths and economic independence. The bio-political fear of the adolescent due to the perceived escalation of the sexualised girl's body in the media is also a factor in this contest over performativity and becoming.

While, in this thesis, I will be analysing both the construction of the ideal feminine in the teen makeover film and examining the representations of the various manifestations of deviant female bodies in the narratives, it is important that I do

${ }^{37}$ Butler, Judith. 'Performative Acts and Gender Constitution: An Essay in Phenomenology and Feminist Theory.' In Writing on the Body: Female Embodiment and Feminist Theory. Eds. Katie Conboy, Nadia Medina, and Sarah Stanbury. (New York: Columbia University Press, 1997). Pg 403.

${ }^{38}$ Ibid. p. 404.

${ }^{39}$ Ibid. p. 413. 
so in observance of the timeframe in which these films were created. While gender performance may always have been instrumental in order for the heterosexual matrix ${ }^{40}$ to be perceived as the product of naturalised inherent human values, the setting in which the makeovers take place in the films I will be analysing indicate a specified fear of what the feminine now means at a time when women are asked to delay motherhood for the sake of a career and to partake as citizens through consumerism. It is clear that in the modern teen makeover film the fear of the increasing instability of the nuclear family translates to a fear of the instability of sexual desire as following on from gender. While postfeminism may aim to shore up heterosexual desire by promoting empowerment through femininity, (which can supposedly be reclaimed in the aftermath of feminism), there is also concern in the teen makeover film that the new emphasis on a feminine consumer culture may threaten to eclipse men altogether. For this reason, the female protagonist undergoes her makeover at the objectified end of a highly controlling gaze - whether the gaze belongs to the key male character or to someone who serves patriarchal interests.

While these films are set in an identifiably postfeminist atmosphere, the theoretical framework I will be using to analyse them is a primarily feminist one. As I have begun to suggest, Judith Butler's work on gender performativity and the heterosexual matrix lends itself particularly well to a series of films that display anxiety at the changing performances of female identity and which seek to construct a woman from a gender ambiguous base into an objectified female spectacle for the male gaze. The protagonist, while seeming to gain a newfound confidence from her 'correct' gender identity, is rendered into a passive position in relation to the male character not only through her transition to bodily spectacle but also due to the reason for her candidature for the makeover - an inner inherent passive and nurturing core. She is re-presented as an ideal in order to resurrect the endangered idealised maternal figure. I will later demonstrate then, the curious blend of postfeminist woman and pre-feminist woman the made-over adolescent

\footnotetext{
${ }^{40}$ Butler Judith. Gender Trouble. (New York, Routledge, 1990).
} 
symbolises. Before any analysis can take place however, key theorists and their relevant work that I will be using must be introduced. Here, I will examine the relevance of Foucault, Butler, and phenomenological theory to my thesis.

\section{Foucault and Bartky: The Regulation of Femininity}

I have already alluded to the idea that the female protagonist 'becomes a woman,' to use the phrasing of Simone de Beauvoir, ${ }^{41}$ under a policing gaze that seems to serve the interests of patriarchy. The Foucauldian idea of a gaze ${ }^{42}$ that polices the body, seeking to regulate its gestures, movements, behaviours, and very mode of thinking is profoundly literalised in the teen makeover film. The gaze belongs to embodied figures acting with authority for the benefit of patriarchy, kinship, and institutionalised heterosexuality. They seek to regulate the wayward figure of the female protagonist who has the potential to become a near perfect citizen if she can only be shown down the right path. And yet, where does this idea of a 'correct citizen' come from? Why do those who 'police' in the teen makeover film have the right to do so? Michel Foucault writes in Discipline and Punish that the human body has entered into a new 'machinery of power' that explores and then regulates the body so that it operates in accordance with the wishes of those who, for instance, in certain institutionalised settings have been given power over others. ${ }^{43}$ Foucault sees these mechanics of power as being at work in institutions such as prisons, schools and the army. Explaining how surveillance as power works, Foucault uses the design of Bentham's Panopticon, which involves a windowed tower in which a supervisor may be stationed and a set of cells each to house an inmate. ${ }^{44}$ The central idea of the Panopticon is that the inmate must never know he is being observed and yet also know that at any time he may be watched. ${ }^{45}$ The inmate, therefore, takes over the responsibility of policing himself, becoming both

\footnotetext{
${ }^{41}$ Ibid. p. 11.

${ }^{42}$ Foucault, Michel. Discipline and Punish. The Birth of the Prison. (Originally published - Paris: Gallimard, 1975).

${ }^{43}$ Ibid. p. 138.

${ }^{44}$ Ibid. p. 200.

${ }^{45}$ Ibid. p. 201.
} 
the observed and the observer - 'he inscribes in himself the power relations in which he simultaneously plays both roles. ${ }^{46}$ The observers of the inmate, importantly, may be temporary and anonymous - virtually any individual can operate the machine. ${ }^{47}$ While those who may act as an observer in the panoptic schema may include teachers, prison workers, doctors etc, it is important that nearly anyone can inspect institutions such as schools or hospitals. ${ }^{48}$ It is not the case that some subjects are free of these mechanics of power, and in fact Foucault has been criticised for undermining the idea of a 'subject' with any kind of agency at all. ${ }^{49}$

In 'Foucault, Femininity and Patriarchal Power,' Sandra Lee Bartky accuses Foucault of treating the body as if it were one unmarked by sex difference. Claiming that women's bodies are in fact produced to be more docile than those of men, Bartky points to the fact that there is a mode of embodiment that is distinctly feminine. ${ }^{50}$ Following on from key feminist debates, Bartky claims that that we are born male or female but not masculine or feminine; that gender does not inevitably follow on from sex. In what is a similar position to Butler, Bartky comments that the gendered body is historically specific, and then goes on to describe how women of today internalise a gaze that polices their femininity. Bartky argues that modern women are infantilised through the current idealised female form, which is 'taut, small breasted, narrow-hipped, and of a slimness bordering on emaciation,' - adolescent-like. ${ }^{51}$ She connects this idealised image to the female obsession with dieting, pointing out that mass circulated women's magazines feature dieting articles in virtually every issue, while women outnumber men in 'Overeaters Anonymous' by over ninety percent. ${ }^{52}$ Using the

${ }^{46}$ Ibid. p. 202.

${ }^{47}$ Ibid. p. 202.

${ }^{48}$ Ibid. p. 207.

${ }^{49}$ McNay, Lois. Foucault and Feminism. (Cambridge: Polity Press, 1992).Pg 48.

${ }^{50}$ Bartky, Sandra. 'Foucault, Femininity and the Modernization of Patriarchal Power.' In Writing on the Body: Female Embodiment and Feminist Theory. Eds. Katie Conboy, Nadia Medina, Sarah Stanbury. (New York: Columbia University Press, 1997). Pg. 132.

${ }^{51}$ Ibid. p. 132.

${ }^{52}$ Ibid. p. 133. 
work of feminist phenomenologist Iris Marion Young, Bartky explores the realisation that female bodily comportment is vastly different to men, with women tending to limit themselves in the amount of space they take up. The German photographer Marianne Wex, observing women waiting for trains, noted that they made themselves appear small, narrow and harmless, while men expanded into the available space. ${ }^{53}$ Feminine movement must not display constriction only, but grace, and female faces must be 'trained in the art of deference. ${ }^{54}$ Female skin must be soft, hairless, smooth, so as to not show signs of age, experience or deep thought, ${ }^{55}$ and Bartky here lists the extensive array of beauty products women are encouraged to buy in order to fit the above criteria.

Like Foucault's school pupil, soldier or prisoner, a woman's beauty regime is timetabled - what she must do every morning and night and what the different products are that she must use at different life phases. ${ }^{56}$ Bartky denies that makeup is an expression of individuality, saying that one who applies it uniquely would be seen as an eccentric, and also denies that to wear makeup is a choice as the woman who chooses not to partake will face sanctions. ${ }^{57}$ These markers of femininity are all part of the process by which the subjected and practiced female body is produced. Women are kept in a state of shame as they are destined to fail in reaching for such stringent standards. ${ }^{58}$ Bartky believes these practices are about making oneself object and prey for the male - 'woman lives her body as seen by another, by an anonymous patriarchal other. ${ }^{59}$ Femininity as spectacle is something which requires the participation of all women. ${ }^{60}$ This kind of discipline brings with it a sense of mastery, and a sense of identity - 'to possess such a body may also be essential to her sense of herself as a sexually desiring and desirable

${ }^{53}$ Ibid. p. 135.

${ }^{54}$ Ibid. p. 135.

${ }^{55}$ Ibid. p. 136.

${ }^{56}$ Ibid. p. 138.

${ }^{57}$ Ibid. p. 139.

${ }^{58}$ Ibid. p. 139.

${ }^{59}$ Ibid. p. 140.

${ }^{60}$ Ibid. p. 140. 
subject. ${ }^{61}$ The image of the Panopticon is at work in that power is anonymous and yet is everywhere - the individual must therefore police himself. For Foucault, it is this operation of power that in actuality creates one's supposed subjectivity or agency. ${ }^{62}$

I have highlighted Bartky's article here as it introduces many key themes in my thesis - that of femininity as constructed, a patriarchal overseeing gaze, the perceived need for gender in terms of cultural intelligibility and, implicitly, how consumer citizenship may be read as being complicit in the policing and regulation of women. While the construction of femininity is interestingly made visible in the teen makeover film, it is also depicted as being necessary in order for the protagonist to overcome her attachment to a dead or absent parent, a resulting incest scenario, and an over association with the mind over body, elements of her 'before' state that I will explore in Chapter Two. The female lived body is one that must be associated with the body, with the mind (or soul) being associated with masculine reason and control. Elizabeth V Spelman in 'Woman as Body' analyses the work of Plato, pointing to his belief that 'integral to the soul/body distinction is the higher worth and importance of the soul in comparison to the body. ${ }^{, 63}$ The soul/body hierarchy lies in parallel to the man/woman hierarchy and is thus integral to patriarchal control. One can see this being played out in the teen makeover film; the ugly duckling character often being associated with the intellectual as well as being unable to invite desire due to her wayward body.

\section{Judith Butler: Theories on Gender Performance}

While Bartky follows on from feminist theory in claiming that sex is fixed while gender is constructed, Judith Butler believes it is wrong to even assume the stability of natural categories of sex difference. Like Bartky, Butler is indebted to

\footnotetext{
${ }^{61}$ Ibid. p. 146.

${ }^{62}$ Ibid. p. 147.

63 Spelman, Elizabeth V. 'Woman as Body.' Feminist Theory and the Body. Eds. Janet Price and Margrit Shildrick. (New York: Routledge, 1999). Pg 38.
} 
Foucault's work, but also to phenomenologist Simone de Beauvoir, and the ideas of Monique Wittig, Luce Irigaray and Julia Kristeva. Like Nietzche and Foucault, Butler cannot conceive of a 'being behind doing,' doing is everything. ${ }^{64}$ Butler writes in Bodies That Matter, that from the very moment a girl is named as such, her subjecthood is constituted - 'brought into the domain of language and kinship through the interpellation of gender.' 65 The 'girling' of the girl then takes place over time through a series of performative acts that produce the sexed body. ${ }^{66}$ Here, a compulsory order in which gender and desire follow naturally from sex is produced. According to Butler, if gender is theorised as being separate from sex then a masculine gender would not necessarily have to belong to a man, nor a feminine gender to a woman. ${ }^{67}$ It is Butler's belief that sex, too, is culturally constructed, as gender 'designates the very apparatus of production whereby the sexes themselves are established.' Gender is the cultural means by which the sexes and oppositional heteronormativity are produced. ${ }^{68}$ Butler argues that a primary homosexual desire is lost due to the taboo against homosexuality - the desire must be abandoned in order to be constituted as a subject. ${ }^{69}$ The subject does not flee the law that constitutes it; rather it becomes attached to it due to the dependency on it for intelligibility. ${ }^{70}$ The body must reject this desire and then become re-signified in a binary gender system. Heterosexuality is thus 'panicked' as gender identity is put forward to be unreal and imitative. ${ }^{71}$ Butler is careful to avoid theorising gender as an act of creation, a problem some have seen with Beauvoir's account of 'becoming a woman.' By arguing that sex is already gender, and by claiming that we can only know sex through gender, Butler overcomes the problematic notion that we are free agents in choosing gender. $^{72}$ Butler acknowledges that people perform gender differently from one another and

\footnotetext{
${ }^{64}$ Butler, Judith and Salih, Sara. The Judith Butler Reader. (Oxford: Blackwell Publishing, 2004). Pg. 6.

${ }^{65}$ Ibid. p. 7.

${ }^{66}$ Ibid. p. 7.

${ }^{67}$ Butler, Judith, Gender Trouble. (New York: Routledge, 1990). Pg. 9.

${ }^{68}$ Ibid. p. 10.

${ }^{69}$ Butler, Judith and Salih Sara. The Judith Butler Reader. (Oxford: Blackwell Publishing, 2004). Pg. 7.

70 Ibid. p. 8.

${ }^{71}$ Ibid. p. 10.

72 Ibid. p. 21.
} 
differently in varying historical time periods, but, following Foucault, any 'choosing' is always culturally constrained. ${ }^{73}$ 'Becoming a gender is an impulsive yet mindful process of interpreting a cultural reality laden with sanctions, taboos, and prescriptions. ${ }^{74}$ Gender is designated through patriarchy and hierarchically structured so that the masculine is privileged over the feminine. ${ }^{75}$ If bodies do not conform to the heterosexual matrix where sex, gender and desire must naturally line up, then they will lead unintelligible, illegible lives. ${ }^{76}$ When couples get together, but the direction of desire is ambiguous, there results a problematic for the 'natural' sex and gender order, a point of particular significance to the teen makeover film. Butler, interpreting Monique Wittig, concludes that gender not only designates persons, but qualifies them as subjects. ${ }^{77}$

Butler's theory that the body is gendered and based on performative acts that become naturalised, and her hypothesis that the heterosexual matrix is denaturalised by drag performance where gender does not follow from sex, have their grounding in phenomenological ideas. The lived body here becomes the site through which meaning is produced and articulated. Similarly, my analysis is influenced by phenomenology, not only through the work of Butler and Bartky here mentioned, but by other theorists with a feminist agenda based on the gendered lived body, for instance Vivian Sobchack and Iris Marion Young. In accordance with Butler's theories on gender as necessary for intelligibility, the protagonist of the teen makeover film, due to her inability to perform femininity as Western society deems appropriate, is an object of disgust for other characters. In order to partake in a romanticised heterosexual relationship, her makeover must take place so that she becomes visible in the eyes of the male character. But, as I have already briefly discussed, what femininity may now signify in a postfeminist age, while reassuring in some ways to patriarchy, may also be threatening toward traditional concepts of the nuclear family. In visibly constructing femininity upon

\footnotetext{
${ }^{73}$ Ibid. p. 22.

${ }^{74}$ Iibd. P. 26.

${ }^{75}$ Lloyd, Moya. Judith Butler. (Cambridge: Polity Press, 2007). Pg. 29.

${ }^{76}$ Ibid. p. 33.

${ }^{77}$ Ibid. p. 34.
} 
a female body in the narrative, the teen makeover film seeks to negotiate the perceived positives and negatives of postfeminism, with the goal in mind to create an idealised girl.

\section{Postfeminism: A Focus on Female Aspiration}

In a thesis that explores films made in a postfeminist climate from a feminist analytical framework, it is important to determine what I take postfeminism to mean - what the different facets of it are, what seem to be its aims, and importantly what its links are to consumerism and citizenship. My summary of postfeminism here will primarily utilise the work of Chris Holmlund in order to differentiate between scholarly postfeminist writing, subcultural movements and postfeminism as adopted popular philosophy. This will prepare the way for a focus on the work of Angela McRobbie, whose work looks at how postfeminism has been represented in popular culture. It is these representations which are of most relevance to the aims of the thesis. It is important however to acknowledge here that there is a wider discourse on postfeminism. Canonical texts include Imelda Whelehan's Modern Feminist Thought: From the Second Wave to 'PostFeminism' (Edinburgh: Edinburgh University Press, 1995), which studies the 'new feminism of the 90s' through a closer look at the work Naomi Wolf and Camille Paglia, and Tania Modleski's Feminism Without Women: Culture and Criticism in a 'Postfeminist' Age (New York and London: Routledge 1991). This book examines the idea that feminism is now no longer necessary while examining how popular culture texts participate in a backlash in the name of feminism rather than against it. For an overview of how postfeminism has been theorised and debated see Sarah Gamble's The Routledge Companion to Feminism and Postfeminism (London and New York: Routledge, 2001).

The term postfeminist has only been applied to texts from the 1980s and according to Chris Holmlund in 'Postfeminism from A to G,' most commentators envision it as being a white backlash that straitjackets sexuality while denying 
class, race and age. Homlund notes that some commentators however celebrate the performance of the 'girlie' or the 'cutthroat competence' of the glamorous executive. ${ }^{78}$ She asks whether postfeminism is an attitude, the way a person thinks and behaves, or an object, an aim or a purpose, and then concludes it to be both. ${ }^{79}$ She argues that postfeminism has had three feminine faces - academic, chick and grrrl (the A to $\mathrm{G}$ of the title of the article in question), believing the most prevalent of the variant to be chick postfeminism. Perceiving chick postfeminists to be generally young or at least dedicated to the idea of youth, Holmlund states that many of these women are hostile to the goals and gains of second wave feminism, while others simply take them for granted. Another type of postfeminist is the riot 'grrrl', which also may be called a third-wave feminist, and who are 'politically engaged yet playful.' They carry on first and second wave fights and acknowledge diversity among women. Holmlund then briefly describes academic postfeminists as being tied to British, American and French poststructural, postcolonial, postmodern and queer theory. ${ }^{80}$

It is important to acknowledge that there are theorists who see a need to separate third-wave feminism from postfeminism, rather than grouping different types under the one banner. Amber Kinser in 'Negotiating Spaces For/Through ThirdWave Feminism' argues that there must be a conception of a third-wave as this would help young women to articulate a feminism that can correspond to today's era and unique circumstances. ${ }^{81}$ She discusses the importance of seeing feminism as evolutionary rather than revolutionary, using her own experiences with feminism to cite problems with the wave metaphor that is used to describe the women's movement. ${ }^{82}$ She divides feminism from postfeminism when writing about how a 'fickle media' turned its attentions to the latter in the 1980s. It seemed that feminism had retreated, and yet Kinser notes the 80s was in fact the

\footnotetext{
${ }^{78}$ Holmlund, Chris. 'Postfeminism from A to G.' Cinema Journal. (44 No 2. Winter 2005) Pg. 117

${ }^{79}$ Ibid. P 116.

${ }^{80}$ Ibid. p. 116.

${ }^{81}$ Kinser, Amber. 'Negotiating Spaces For/Through Third-Wave Feminism.’ NWSA (V 16. 2004). Pg. 124.

${ }^{82}$ Ibid. p. 127.
} 
only decade to have two World Conferences on Women. ${ }^{83}$ Kinser alludes to an important point here in noting a conflict between feminism and postfeminism that is played out in the media (including popular culture texts as we shall see in my later analysis), the latter often scorning and smothering the former. Kinser uses four points to define what she perceives a third-wave feminist to be, despite emphasising that feminism cannot be entirely divided into 'waves.' A third-wave feminist would come to young adulthood as a feminist and practice feminism in a 'schizophrenic cultural milieu,' which while granting the right to improved opportunities and resources also resists a feminist politics which would enable them to 'lay claim to, embody and hold on to the same.' A third-wave feminist would embrace pluralistic thinking within feminism due to the more prominent voice of non-white women and global feminists, and they would live feminism in a constant tension with postfeminism. ${ }^{84}$ Kinser believes, however, that it is postfeminism that predominantly entices many young women. ${ }^{85}$

It has been necessary to cleave postfeminism into its different facets because the films that I will be analysing overwhelmingly represent what Holmlund would call C or chick postfeminism, which constitutes a significantly different set of aims and values from what Kinser perceives third-wave feminism to be. It is postfeminism and its promises, whether for the good or bad, that the teen makeover film focuses on. However, feminist agendas (perhaps more identifiably the goals of the second wave rather than third wave) may be alluded to when casting the protagonist in her 'before' state as a misfit. It is true that much popular culture centering on women seems to deal with postfeminism predominantly, but feminism is always hovering, partially present only to be repressed. To understand the tensions between feminism and postfeminism and how the latter relates to the former, a look at the work of Angela McRobbie is paramount. The tensions and the deeper operations of chick postfeminism must first be understood before an analysis of the teen makeover film can begin.

\footnotetext{
${ }^{83}$ Ibid. p. 129.

${ }^{84}$ Ibid. p. 133.

${ }^{85}$ Ibid. p. 134.
} 


\section{Chick Postfeminism: A Look at the Work of Angela McRobbie}

In The Aftermath of Feminism: Gender, Culture and Social Change, Angela McRobbie argues that we are experiencing a postfeminist climate in that there is a new anti-feminist sentiment, which differs from 70s and 80s backlash politics, against the gains of feminism. McRobbie convincingly illustrates that elements of feminism have been taken into account, incorporated into political and institutional life and converted into an individualistic discourse that works as a substitute for feminism in order to keep it from re-emerging. ${ }^{86}$ Feminism has been abandoned for the sake of intelligibility as a woman (a matter which as we shall see later is of great importance in the teen makeover film), and this abandonment is rewarded with the promises of freedom and independence through wage earning capacity, 'which also functions symbolically as a mark of respectability, citizenship and entitlement. ${ }^{, 87}$ McRobbie's work in this book is predominantly centred on representations of women past their adolescence, however it is my belief that these representations are also important in my analysis. While I will be focusing on girl power images later in this chapter, it is necessary here to introduce the chick postfeminist because the two categories here mentioned are not mutually exclusive. The girl power icon and chick postfeminist are both part of a larger postfeminist framework that may be defined by a certain attitude and aims that are evident in both representations of adolescents and older women. It is also true that just because a popular culture text is aimed at a certain demographic that this is the only age group that will become a viewer. However, there are a certain set of fears directed toward the time of possibility and malleability caught up in the 'in-between' state that is adolescence, and desire placed on the adolescent body is markedly different from that signified by the chick postfeminist. The chick postfeminist is also important because she represents the future - what the adolescent could supposedly grow into if she absorbed these media images and believed in all the promises of a consumer lifestyle that the larger context of postfeminism offers. It is important to note that while the chick

\footnotetext{
${ }^{86}$ McRobbie, Angela. The Aftermath of Feminism: Gender, Culture and Social Change. (London: SAGE Publications Ltd, 2009). Pg. 1.

${ }^{87}$ Ibid. p. 2.
} 
postfeminist may indicate a woman older than an adolescent, she is still rarely past the age of forty. An aspect of postfeminism is its strong emphasis on youth. Sarah Projansky writes that it is girl discourse that both contributes to and sustains postfeminism, with slogans such as 'girls rule' and 'you go girl' able to be marketed as readily to grown women as to young girls and teens. Chick postfeminism is in fact modelled on the in-between state of adolescence, as the ideal postfeminist woman is always in process, constantly aiming to achieve her goal to 'have it all.' However, she is never quite successful in this aim and therefore never reaches full adulthood. ${ }^{88}$ There is a fear evident in the teen makeover film that teenage girls will be intercepted in their time of susceptibility and malleability by popular postfeminist discourse and as a result will not be able to fulfill an idealised role in the familial structure. They may be doomed to live a life of perpetual simulated adolescence.

A feminist agenda is included in the plotlines and focus of many forms of popular film, such as more political mainstream films like Erin Brockovich (Steven Soderbergh, 2000) and North Country, (Niki Caro, 2005), but also in romantic comedies such as How to Lose a Guy in Ten Days (Donald Petrie, 2003) or farcical remakes like Charlie's Angels (McG, 2000). There is often a feminist agenda in television programmes such as Sex and the City or Charmed among countless others, and women's magazines like Cosmopolitan and Marie Claire seem to exhibit a commitment to feminist issues. ${ }^{89}$ McRobbie believes that a redrafting of gender hierarchies is taking place ${ }^{90}$ and cites Judith Butler's book Antigone's Claim, which suggests that postfeminism can be described as a double entanglement in that there is a co-existence of neo-conservative values in relation to family life, sexuality and gender with liberal processes in regard to choice and

\footnotetext{
${ }^{88}$ Projansky, Sarah. 'Mass Magazine Cover Girls: Some Reflections on Postfeminist Girls and Postfeminism's Daughters.' In Interrogating Postfeminism: Gender and the Politics of Popular Culture. Eds. Diane Negra and Yvonne Tasker. (Durham and London: Duke University Press, 2007). Pg 45.

89 . McRobbie, Angela. The Aftermath of Feminism: Gender, Culture and Social Change. (London: SAGE Publications Ltd, 2009) Pg 5.

${ }^{90}$ Ibid. p. 7.
} 
diversity in sexual, domestic and kinship relations. ${ }^{91}$ Butler's article 'Is Kinship Always Already Heterosexual?' hypothesises that the greater recognition of gays and lesbians into the world of family and marriage has come with a price, in that alternative forms of kinship and raising a family must be put aside. ${ }^{92}$ She notes that there is a strong investment now in the normalisation of family life in Western societies due to concerns about global migration. The allowing of same sex couples into the two-parent household could be seen as an attempt to 'shore up the nuclear family against whatever perceived threat it now faces. ${ }^{93}$ McRobbie adds that it is no coincidence that the most demonised category as an alternative to the nuclear family is the single mother. She points out that one would only engage in an alternative familial structure to the two-parent household in desperation. ${ }^{94}$ But as we shall see later there are alternative forms to the nuclear family in postfeminism that may actually be celebrated.

McRobbie uses the film Bridget Jones Diary, as well as characters in Sex and the City and Ally McBeal in order to provide an illustration of the postfeminist woman. She describes these women as confident in declaring anxiety about the possible failure in finding a husband. They brazenly enjoy their sexuality, without fear of the sexual double standard and they avoid aggressive or overtly traditional men. The degree of shame they feel in not being able to find a husband is overridden by sexual confidence. ${ }^{95}$ McRobbie reads these texts as conveying the idea that feminism has robbed women of treasured pleasures including romance, gossip and the obsessive concern with finding a husband. ${ }^{96}$ McRobbie additionally points out that these women are more than capable of earning their own living. Karen Boyle in 'Feminism Without Men: Feminist Media Studies in a Postfeminist Age' quotes Brunsdon, who has added to this argument in noting that many popular female characters in film (for instance the Melanie Griffith and

\footnotetext{
${ }^{91}$ Ibid. p. 12.

${ }^{92}$ Ibid. p. 50.

${ }^{93}$ Ibid. p. 50.

${ }^{94}$ Ibid. p. 51.

${ }^{95}$ Ibid. p. 21.

${ }^{96}$ Ibid. p. 21.
} 
Julia Roberts characters in Working Girl, Mike Nichols 1988, and Pretty Woman respectively) are both formed by and disavow feminism. They are not trapped in femininity nor rejecting of it, but use it to their advantage in the workplace and bedroom. ${ }^{97}$ Thus it is femininity and the feminine pleasures that feminism is accused to have stolen from women that is presented as the ultimate means to succeeding in a feminist agenda. To gain empowerment, however dubious the acquisition may be in some of these texts, the woman must first be intelligible within the terms of the heterosexual matrix.

\section{Young Women as Keys to a New Future}

After discussing the retrenchment of gender hierarchy, regulation of kinship, and the accoutrements of the postfeminist woman in popular culture texts, Angela McRobbie points to the new sexual contract women are being asked to engage in in society. Here, young women and adolescents are conflated as being keys to a new future, and this sexual contract which is offered in society makes its way into our media images. This contract asks women to make use of the opportunity to work, to get qualifications, control fertility and earn enough money to participate in consumer culture, which she says is a 'defining feature of contemporary modes of citizenship. ${ }^{98}$ Young women are being illuminated in the public sphere, and their gains are supposed signs of a democracy in good health. ${ }^{99}$ McRobbie believes that the dynamics of control and regulation are not centered around what young women ought not to do, so much as what they can do. ${ }^{100}$ The abandonment of a critique of patriarchy is a requirement of this contract, the young female signifying modernity and progress. ${ }^{101}$ The young woman is directed towards

\footnotetext{
${ }^{97}$ Boyle, Karen. 'Feminism Without Men: Feminist Media Studies in a Postfeminist Age.' In Feminist Television Criticism: A Reader $2^{\text {nd }}$ Edition. Eds Charlotte Brunsdon and Lynn Spiegel. ( Berkshire: Open University Press, McGraw-Hill Education, 2007). Pg 177.

${ }^{98}$ McRobbie, Angela. The Aftermath of Feminism: Gender, Culture and Social Change. (London: SAGE Publications, 2009). Pg. 54.

${ }^{99}$ Ibid. p. 57.

${ }^{100}$ Ibid. p. 57.

${ }^{101}$ Ibid. p. 58.
} 
independence, which requires that she become important to herself. In times of stress, she is encouraged to seek counselling. ${ }^{102}$

Anita Harris in Future Girl: Young Women in the Twenty First Century has also written about the fact that young females are now the focus in a time of social, cultural and political change. Calling this public presentation of the ideal construction of the feminine 'the future girl,' Harris notes that this young woman is 'celebrated for her desire, determination and confidence to take charge of her life, seize chances, and achieve goals. ${ }^{103}$ The fact that an increasing amount of goods and services are targeted toward the girl is evidence of her visibility. ${ }^{104}$

Nancy Lesko in 'Act Your Age' writes that adolescence has often been a social space where the characteristics of people in modernity are talked about and where policies and programmes are put in place in order to help create a new modern social order and model of citizenry. ${ }^{105}$ Harris believes ours is a 'risk society,' under threat because of religious conflict, health threats, fragile economies and security concerns, citing a shift from a focus on production to a focus on consumption as evidence of new times of individualisation and of meaning making and identity. ${ }^{106}$ She writes about the expansion of consumer capitalism, the connection between consumption and the middle classes and hence the need for two incomes within families in order to sustain the lifestyle. ${ }^{107}$ These changes allow modern young women to believe they are enjoying a new kind of liberation and increased opportunity. They are encouraged that girls can do anything. ${ }^{108}$ However, Harris points out that this 'popular story' can only remain in place by masking the stories of those who do not resemble the ideal construction of the 'can do' or 'future girl.' The failures of those who do not conform are put down to

\footnotetext{
102 Ibid. p. 60.

${ }^{103}$ Harris, Anita. Future Girl: Young Women in the Twenty First Century. (New York and London: Routledge, 2004). Pg. 1.

${ }^{104}$ Ibid. p. 1.

${ }^{105}$ Ibid. p. 1.

${ }^{106}$ Ibid. p. 4.

107 Ibid. p. 7.

${ }^{108}$ Ibid. p. 8.
} 
their own poor choices or perhaps irresponsible families or lazy communities. ${ }^{109}$ These 'at risk' youth are often characterised through their disordered consumption patterns (drugs, smoking, drinking) as opposed to the 'can do girls, future glamour workers whose lifestyle is bound up with buying the correct products and accessories in order to present the self adequately. ${ }^{110}$ Harris believes government policy and agenda setting is focused on creating economically independent women through, initially, the school system - 'creating docile good girls who can uncomplainingly participate in meeting the needs of the marketplace. ${ }^{111}$ As such, traditional conservative family values are being reshaped as motherhood must be delayed - which from a conservative perspective renders reproduction under threat. $^{112}$ Angela McRobbie writes that as the result of women becoming less dependent on men it becomes all the more important for the terms of heterosexual desire to be secured. ${ }^{113}$ The voice of consumer culture produces a specific female subject - the subject is encouraged to always be self-perfecting: self imposed feminine cultural norms mask patriarchal authority. ${ }^{114}$

There are, however, some theorists who aim to recuperate feminine consumer cultures, seeing aspects that may work to resist patriarchy. Jane Arthurs in 'Sex and the City and Consumer Culture: Remediating Postfeminist Drama' argues that unlike much postfeminist drama, this show is not about women wanting to get married. Arthurs believes the series defies bourgeois codes that used to be demanded of respectable women and instead removes the shame of being single and sexually active. ${ }^{115}$ In Sex and the City, women's sexual pleasure and agency are encouraged as part of a consumer lifestyle. ${ }^{116}$ Arthurs notes the argument that

\footnotetext{
${ }^{109}$ Ibid. p. 9.

${ }^{110}$ Ibid. p. 23.

111 Ibid. p. 19.

112 Ibid. p. 23.

${ }^{113}$ McRobbie, Angela. The Aftermath of Feminism: Gender, Culture and Social Change. (London: SAGE Publications, 2009). Pg. 62.

${ }^{114}$ Ibid. p. 63.

${ }^{115}$ Arthurs, Jane. 'Sex and the City and Consumer Culture: Remediating Postfeminist Drama.' In Feminist Television Criticism: A Reader $2^{\text {nd }}$ Edition. Eds. Charlotte Brunsdon and Lynn Spiegel. (Berkshire: Open University Press, McGraw-Hill Education, 2007). Pg. 43.

${ }^{116}$ Ibid. p. 44.
} 
female viewers may be invited to share the male gaze, which is internalised in women's scrutinising relationship to their appearance and bodies, but puts up a persuasive counter argument in saying that feminine cultures of fashion and consumerism could be considered as pleasurable sources of power that may be resistant to patriarchal control. It may be an alternative route to self esteem and autonomy that overcomes the division that second wave feminism constitutes between feminism and femininity. ${ }^{117}$ Arthurs uses the work of Rachel Bowlby, who has referred to the ideal modern consumer has having no moral self or consistent identity, to illustrate the fact that in Sex and the City aesthetic boundaries replace moral ones, so that for instance, men who are too short or do not kiss well, might be rejected for these reasons. ${ }^{118}$ Arthurs believes that in this text, dependence on male lovers is displaced as they always disempower or disappoint. $^{119}$ A stiletto shoe or a handbag on the other hand can always be possessed - a fetish substitute for what the male promises to provide but does not. 'The autoeroticism legitimated by the narcissistic structure of the look in consumer culture offers the possibility of doing without men at all., ${ }^{, 120}$

It may seem unusual to go into depth about an article that focuses on a particular text that does not seem to have much in common with the films to be under discussion here (it is not about adolescents or makeovers). However, the argument that Arthurs puts forward here is of great significance to my analysis. Although these films aim to mould an ideal feminine that in many ways fit the criteria that McRobbie describes in her writing on the postfeminist climate and the new sexual contract, at the same time there is a very present fear that the push towards consumerism may lead to a type of empowered exclusive sisterhood that scorns and rejects men. The replacement of men with money is a key concern for the teen makeover film, which aims to stabilise the nuclear family by cementing the gender binary.

\footnotetext{
${ }^{117}$ Ibid. p. 45.

${ }^{118}$ Ibid. p. 51.

${ }^{119}$ Ibid. p. 52.

${ }^{120}$ Ibid. p. 52.
} 


\section{Postfeminist Girl Icons and Girl Power}

Anita Harris's 'future girl' describes how adolescents and young women are the objects of an intense focus as they are lauded for their successes in education, their newfound equality, their opportunities on a par with men. Due to the shift from production to consumption, they are encouraged to embark on careers that will enable them to partake in a consumer culture, delaying motherhood. The image of the young, professional educated career woman with the glamorous consumer lifestyle is everywhere. ${ }^{121}$ This image is a seductive one - this is a woman who 'has it all,' and this is the woman we are encouraged to be. But it is also a deceptively difficult image to emulate. While adolescents in school are being encouraged more than ever to work hard, to participate in extracurricular activities and earn straight As in order to achieve careers that previously would not have been available to them, they are also encouraged to embody stringent feminine beauty ideals through their older media idols. Ally McBeal, the Sex and the City or Lipstick Jungle girls, as well as some of the characters in Desperate Housewives, may be successful career women, but they are also commonly youthful in appearance and attractive with an investment in beauty and maintaining an idealised slim physique, indicative of their 'controlled and controlling' personas. The pressure on female adolescents to be all things to everyone when they grow up; to be emblematic of a society moving forward, is huge. And, of course, only very few have the capacity to reach this ideal. Those who don't have this capacity are condemned to invisibility or to be pronounced at risk due to disordered consumption patterns. ${ }^{122}$ Despite the greater investment in girls' academic achievement, one could convincingly argue that in the age of the image, the career of many a televised postfeminist woman is secondary. What is important is status, the lifestyle, large modern apartments, fashionable clothes, and the freedom to live life independently if necessary. The fact that these characters would have to work hard for many years to achieve their workplace status is often not important - it is their arrival, their achievements, that is desirable and which

\footnotetext{
${ }^{121}$ Harris, Anita. Future Girl: Young Women in the Twenty-First Century. (New York and London: Routledge 2004). Pg. 8.

${ }^{122}$ Ibid. p. 28.
} 
can be obtained briefly through identification practices when watching a show and through consumer habit. While it is true that shows I have already mentioned do have adolescent followings, adolescents and a slightly younger set, 'tweens,' also have a separate group of girl icons they look up to and spend their dollars on.

As it is for slightly older women, the 'image' is paramount for today's adolescents. In a world where teenage girls are told they must achieve high test scores in order to succeed in life, as well as be efficient in oratory, music, sport, be kind and helpful as well as confident, it does not seem so far-fetched that fame in the popular culture arena may look like a simpler alternative route to becoming successful. This is seemingly a life of wealth and consumption without the conventional gruelling hard years of study or practice to get there. To matter, to become famous, one only needs the right look and some talent, both of which can be manufactured to an extent to fit a mould, and also a special elusive 'star quality. ${ }^{123}$ All of the above criteria a girl may imagine she can fulfil, and if not, that she can somehow acquire the ingredients through a special relationship with her favourite star.

Susan Hopkins writes in Girl Heroes: The New Force in Popular Culture that celebrity pop culture stories centred on the path to fame are reminiscent of enchanted fairytales. The Princess practices her dance steps knowing that one day a talent scout will spot her and carry her off, saving her from (dreaded) anonymity. ${ }^{124}$ The story is a rags to riches one - a discovery of true beauty. Importantly here, and differentiating from the fairytale, the prize is not love or romance, it is fame and money - making it. ${ }^{125}$ The new stereotype of ideal young femininity, according to Hopkins, is the cute but powerful girl/woman. Tough,

\footnotetext{
${ }^{123}$ Richard Dyer writes about the combination of magic and talent that is thought to belong to the famous in Stars. (London: British Film Institute, 1998). Pg. 16.

${ }^{124}$ Hopkins, Susan. Girl Heroes: The New Force in Popular Culture. (Annandale: Pluto Press, 2002). Pg. 59.

${ }^{125}$ Hentges, Sarah. Pictures of Girlhood: Modern Female Adolescence on Film. (North Carolina: McFarland and Company Inc, 2006). Pg 78.
} 
strong and ambitious but sexy at the same time. ${ }^{126}$ This stereotype is emblematic of a wider consumer culture encompassed under the 'girl power' mantra. Being a girl in this image is lauded in popular culture and is used to sell product after product. It is McRobbie's representational postfeminism, an intelligible endearing femininity combined with a feminist agenda, that finds its way into the signification of the girl power icon. It is necessary to note that the girl hero is not the same as the glamorous chick postfeminist, although there are a number of similarities and overlapping points which make each important.

For the girl power star, particularly the pop star, fame and domination through the circulation of her brand is the ultimate goal. In the words of Britney Spears, (actually an unstable girl power icon as I will discuss later). 'I want to be a legend like Madonna. That's what I strive for. That's what I pray for every day. ${ }^{127}$ Susan Hopkins believes that in the postmodern girl world, fame has replaced marriage as the imagined means to realising female dreams. ${ }^{128}$ It may seem unusual here to compare fictive characters such as Bridget Jones, held up by McRobbie as a product of chick postfeminism, ${ }^{129}$ to a 'real' person like Britney Spears, but, of course, Britney Spears the brand is as much a construct as any postfeminist televised character, although they may be able to maintain a separation between actress and role that Britney cannot. Pop stars like the Spice Girls are girl power icons, this is true, but there are numerous television character counterparts in Buffy the Vampire Slayer, Hannah Montana, The Powerpuff Girls, and Dark Angel. ${ }^{130}$

\footnotetext{
${ }^{126}$ Hopkins, Susan. Girl Heroes. The New Force in Popular Culture. (Annandale: Pluto Press, 2002) Pg, 1.

${ }^{127}$ Ibid. p. 11.

${ }^{128}$ Ibid. p. 4.

${ }^{129}$ McRobbie, Angela. The Aftermath of Feminism: Gender, Culture and Social Change. (London: SAGE Publications, 2009). Pg 12.

${ }^{130}$ For more on how these shows and others are said to negotiate feminism and gender representations see Teen TV: Genre, Consumption and Identity. Eds: Glyn Davis and Kay Dickinson. (London: British Film Institute, 2004); Rachel Moseley’s 'Glamorous Witchcraft: Gender and Magic in Teen Film and Television' in Screen 43(4), 2002; and Sarah Banet-Weiser's ‘Girls Rule! Gender, feminism and Nickelodeon,' in Feminist Television Criticism: A Reader $2^{\text {nd }}$ Edition. Eds: Charlotte Brunsdon and Lynn Spigel. (Berkshire: Open University Press, McGraw-Hill Education, 2007). Buffy in particular is a text that has received much critical attention and has been explored in Buffy the Vampire Slayer and Philosophy: Fear and Trembling in Sunnydale. Eds: William Irwin and James B South (Chicago and La Salle: Open Court Publishing Company: 2003), as well as in Lorna Jowett’s Sex and the Slayer: A Gender Studies Primer for the Buffy Fan. (Connecticut: Wesleyan University Press, 2005).
} 
Susan Hopkins writes that girl power is linked to celebrity power, with marketers aiming to build relationships between celebrities and the girls who worship them that are channelled toward increased consumption. ${ }^{131}$ Celebrity culture rewards 'feminine pleasures' of image, makeup and masquerade. ${ }^{132}$ Referring back to Sandra Lee Bartky's article then on women living their lives under an intense internalised patriarchal gaze that regulates their bodily movement, and enforces a strict makeup and infantilising beauty regime, it may seem little wonder that girls seek reward for their adherence to the rules of femininity through the ultimate visibility - fame. In fact, this is a promise embedded within the narrative of the teen makeover film. The teens often gain visibility, power and an iconic status within the space of the school through their new corrected image. Real life girls, sold on the rags to riches fairytale stories of stars like Britney Spears, Lindsay Lohan, Hilary Duff, Pink, Rihanna, and the Spice Girls line up for global reality TV shows like Idol, America's/Britain's/NZ's Got Talent, and Next Top Model hoping to be discovered not only for talent, but in equal measure for the fact that they have the 'right look,' or more accurately that they have managed to carefully emulate the look of their idols. The protagonist of the makeover film, like the Cinderella character in the popular fairytale, is rewarded with the look for her traditionally feminine passive, nurturing virtues, and these virtues are in actuality in stark contrast to the new female teen attitude modelled by the girl power icon.

Susan Hopkins writes that the girl power promise of fame, individual success, fortune and sexual agency has replaced the domestic model of femininity which tied girls to romance and marriage. ${ }^{133}$ The girl power hero, icons of which include Madonna, Buffy and the Spice Girls, are often verbally and/or physically aggressive. They are not necessarily caring and sharing, but can be driven by revenge or a lust for material gain (in narrative, lyrics or sometimes through their 'real life' persona). Here there are of course conflations with the chick

\footnotetext{
${ }^{131}$ Hopkins, Susan. Girl Heroes: The New Force in Popular Culture. (Annandale: Pluto Press, 2002). Pg. 4

132 Ibid. p. 5.

${ }^{133}$ Ibid. p. 28.
} 
postfeminist, which overlaps with the girl power icon, each influencing, borrowing, feeding off the other. They are as such, both influential in the construction of the narrative of the films I will be analysing. The girl power icon may be manipulative, deceitful, and can assume many different identities. ${ }^{134}$ The girl hero may play upon the contradictions of postfeminism - that one must be feminist and feminine. There may be potentially progressive elements to the girl power hero - for instance many of the plotlines in Buffy the Vampire Slayer centre on the heroine defeating monsters whose aim it is to do violence to Sunnydale's 'real' girls and women. ${ }^{135}$ Both Madonna and Geri Halliwell have drawn attention to the construction of the Madonna/Whore dichotomy through music videos where they perform both sides of the binary. ${ }^{136}$ And then again, the argument could be made that Madonna, for instance, has no progressive potential because she simply offers a series of never ending images - she aims to push buttons rather than commit to a political idea. ${ }^{137}$ The Spice Girls are indebted to the Riot Girl underground movement, having removed the rebellion and anger from this feminist punk rock subculture, and instead replacing angry lyrics with songs about friendship and love. They are re-selling the claim to female assertiveness through a camp packaged group manufactured to resemble a powerful sisterhood. ${ }^{138}$

There is in fact a strong emphasis on friendly sisterhoods in both older chick postfeminist texts and within girl power pop groups and television programming. The emphasis in these groups is on friendship and the dynamics within the girl group being the primary relationship, eclipsing the need for a man. The unified exclusive girl gang formula has been picked up and mapped onto other pop groups and television premises. The gang girl group is built on a constructed sisterly solidarity - they don't need men if they have each other. The group is a safety net - ready to catch members when men inevitably let them down. The protective

\footnotetext{
${ }^{134}$ Ibid. p. 6.

${ }^{135}$ Bavidge, Jenny. 'Chosen Ones: Reading the Contemporary Teen Heroine.' In Teen TV: Genre, Consumption and Identity. Eds. Glyn Davies and Kay Dickinson. (London: The British Film Institute, 2004). Pg. 50.

${ }^{136}$ Hopkins, Susan. Girl Heroes. The New Force in Popular Culture. (Annandale: Pluto Press, 2002).

${ }^{137}$ Ibid. p. 46.

${ }^{138}$ Ibid. p. 32.
} 
sisterhood is a trope also seen on television in series such as Charmed and for slightly older viewers, Sex and the City. The idea of the girl gang is then being marketed to women of all ages - girl group Destiny's Child even recreating a Sex and the City scenario for one of their videos. The girl group is clearly successful commercially - girls can partake in the 'gang' by looking, eating, smelling, like the members. They can belong to fan clubs that guarantee their membership. The girl group members are usually sexualised, overtly so in some cases, (for instance the recently manufactured group The Pussycat Dolls), and it may be true that a great deal of their appeal lies in the fact that males are attracted to them. However, male love interests are often dismissed in girl gang lyrics or plotlines as trivial. These groups appear to be giving women the knowing wink; men cannot possess them, in fact men are situated textually within masochistic relationships to the star performers where the women fall in and out of love, come closer and then pull away, give and then take away. This formula grants possession of the star rights mainly to the female consumer, who can engage in the illusion of possessing the star by buying into her/their brand - becoming part of their posse dollar by dollar.

The teen makeover film also has a girl gang at its core - not however as the heroes of the piece, but as the villains. The girl antagonists are supposedly simulations of the real; embodiments of an indictment of clique hierarchies within American schools and who their victims are. For instance, following the release of Mean Girls, star Lindsay Lohan appeared on the Dr Phil show where he confronted a real life school clique, similar to the film's 'The Plastics', aiming to decode their mechanics of power and to force them to see the error of their ways. The head of the girl gang in the teen makeover film has many of the same characteristics as the girl power icon - she is sexually knowing, she is confident, often verbally aggressive, and a leader in fashion, setting the trends for others to follow. Like Madonna or Geri Halliwell in the music videos mentioned by Susan Hopkins, the girl gang member in the teen makeover film may knowingly manipulate patriarchy's designated Madonna/Whore roles in order to gain control over other characters in her power-crazed agenda. 
However, in the narrative she is clearly situated as whore as opposed to the protagonist's virtuous virgin; ${ }^{139}$ whom the latter of is initially situated as outside language - her femininity to be constructed by 'those who know best.' I wish to draw attention here to a connection between today's girl heroes and to those who are demonised in the films I will be analysing because it lays the foundation for my hypothesis that these films do articulate a fear about aspects of postfeminism. This is not just a fear of consumer culture entwined with the iconography of the girl power symbol who particularly appeals to teens and tweens, but what postfeminism promises more generally - identity through consumer citizenship, sexual freedom.

McRobbie's view, based on Judith Butler's theories, is that postfeminism involves a re-securing of the kinship structure and the terms of heterosexual desire. This is valid and evident in many texts, and is certainly a dominant aim of the teen makeover film. However, the girl power icon, who is marketed to the same audience as that which the teen makeover film is trying to reach, may be part of a sisterhood that functions as an alternate family - a family which places sisterly bonds over heterosexual romance. Girl groups, pop performers and television icons may be sexualised, they may play into male fantasies, but their images for the females, who most of the time are their main fans, rely on the idea that they are exploiting male views of them as sex objects. It is this aspect of girl power that the teen makeover film takes umbrage with, and this can be seen through their characterisation of villainous characters, which resemble these girl power icons. The teen makeover film appears to fear that the aspect of the girl power brand that favours visibility over romance could be appropriated by girls in a way that could undermine the nuclear family and patriarchy, which produced the images in the first place. The teen makeover film then could be seen to involve a war between the different facets of postfeminism, itself made up of impossibly irreconcilable contradictions.

\footnotetext{
${ }^{139}$ Molly Haskell discusses the virgin/whore dichotomy in relation to constructions of female characters in cinema in From Reverence to Rape: The Treatment of Women at the Movies. $2^{\text {nd }}$ ed. (Chicago and London: University of Chicago Press, 1987). Pg xiii.
} 


\section{The Significance of the Virgin Girl Idol}

In introducing the filmic girl gang, and presenting the girl power icons it has evolved out of, I have focused on a very specific type of prevalent girl idol. This girl power pop icon often may be in her twenties or thirties plus (i.e. Fergie, Gwen Stefani or Madonna), and produced from the start to be sexually knowing, to perform a number of different fantasies and to play with many identities and culturally iconic images. While Gwen Stefani and Fergie may play with the image of the eroticised child in their videos 'Hollaback Girl' and 'Fergalicious' respectively, this is just one of a number of rotating images in their lexicon. Similarly, on television, Buffy the Vampire Slayer and the Charmed girls use a simpering girlishness as a weapon in order to ensnare and kill villains. The first image in the first episode of Buffy the Vampire Slayer was in fact of a vampire masquerading as a Britney Spears-like school girl wandering through darkened halls clinging to her gung-ho date, whimpering about her fear of the dark. This is part of her ruse to trap the date before her girl victim turns vampire predator, penetrating the unsuspecting male with her bite in a subversion of a date rape scenario. While twenty-something icons such as Britney Spears and Christina Aguilera now, like the girl gang members aforementioned and other girl power icons, engage in fetishistic masochistic Madonna/Whore play as part of a set of rotating images when performing, it was not the case when they began their careers as adolescents. The teenage star performing for teenage fans is not the same as the girl/woman star performing for teenage fans.

What Britney and Christina have in common, along with their more recent counterparts Miley Cyrus and Vanessa Hudgens, is that they were once part of the Disney machine and as such were tied in with a Disney image. This is important to my argument, because while I have introduced the idea that the teen makeover film deals with the problematic construction of femininity in a postfeminist time that inevitably must be influenced by the girl power icon and the chick postfeminist, these films are also often a product of Disney. Some of the teen makeover film stars, namely Lindsay Lohan of Mean Girls and Hilary Duff of $A$ 
Cinderella Story, were also born out of the Disney world, and as such also had the clean wholesome image to uphold. Unlike Hilary Duff however, Britney and Christina's music was not directly linked in with a Disney contract, but much was made in the press of their similar starts as 'Mouseketeers.' Britney and Christina's original image was one tied up with a girlish innocence - sexual yet supposedly unaware of this fact. Both of these stars, like actress Lindsay Lohan, followed a simulated coming-of-age in the public eye in order to fulfil the eventual girl power criteria, which as I have discussed is distinctly characterised by knowing sexuality, a claim to independence, a 'don't give a shit' attitude. The girl-towoman star narrative is one of Virgin to Whore or good girl to bad girl. Rihanna, a current pop icon whose managers have copied the Spears/Aguilera innocent to dirty formula, even has a song entitled 'Good Girl Gone Bad.' There is an emphasis here on keeping good girls and bad girls separate, despite the underlying contradictions in the initial little girl persona. While older pop stars may play sexualised little girl from time to time, for the adolescent pop star or Disney actress this is her image.

Kathleen Sweeney in Maiden USA: Girl Icons Come of Age writes about the significance of the virgin imagery surrounding the adolescent star. Sweeney writes about the continual double standard in terms of a virgin/slut culture, ${ }^{140}$ and explores the iconography of the Virgin Mary as vessel for God. In Christianity, the virgin symbolises a submission to God's will. ${ }^{141} \mathrm{I}$ would add here that the corruptible virgin is also a particularly male fantasy - she is innocent, pure, territory waiting to be marked. To 'take' someone's virginity is to be an active agent in signing their body with new sexual and ultimately cultural meaning. Britney's virginity may not so much have been about her being a role model for young girls, the official conservative line, but about positioning her as being perpetually possessable within a cultural vocabulary of what it means to be possessed. There is a unique space carved out here for girl consumers to be co-

\footnotetext{
${ }^{140}$ Sweeney, Kathleen. Maiden USA: Girl Icons Come of Age. (New York: Peter Lang Publishing, 2008). P. 28. ${ }^{141}$ Ibid. p. 45.
} 
possessors, as is the case with the girl gang and the postfeminist girl power icon, but the 'virgin' label is such a powerful marker of identity and it has firm roots in patriarchal discourse. It indicates ripeness for submission, a girlish naivety that coquettishly yearns to be more sexually informed yet does not want to be blamed for it. There are, for me, potentially more subversive elements in the girl power icon rather than the virgin star, or to use Sweeney's terms 'jailbait' or 'lipstick Lolita.' Obviously, there are problematics concerning the girl power icon, for instance a presentation of the sexualised body as the ultimate form of empowerment that does nothing to counter the continual trend of talking about the worth of singers or actresses and ultimately everyday women in terms of body parts. The physical attributes of female stars, for instance Cameron Diaz's legs or Angelina Jolie's lips, are seen as integral to their screen success and thus function as capital within their industry. When these stars advertise certain products to consumers, they encourage us to also invest in our bodies in order to 'empower' ourselves in accordance with what it means to be empowered within a postfeminist culture. ${ }^{142}$

I have discussed the pop virgin to slut narrative here because there is an invocation of this formula in the teen makeover film, in contrast to the girl power icon's slipping and sliding between gender Madonna/Whore identities and play on male fantasy. In these films' narratives there is a return to the traditional split between good girl and bad girl - a plot clearly evident in classical Hollywood films, but importantly also a modern recurrence in Disney or Disneyesque plots reliant on fairytale tropes to instil and maintain conservative family values. The good girl protagonist is nearly always virginal, a sexual naïf, in contrast to the antagonists who keep their high school boyfriends like puppets on a string. The good girl protagonist can not be paralleled with the teen virgin star as strongly as the girl power icon can be with the antagonist, as historical makeover film tropes for the main character must be employed, which usually involves class

\footnotetext{
${ }^{142}$ Jackie Stacey explores how female consumers act on their desire to become more like their screen ideals in an attempt to close the gap between self and idealised other in Star Gazing: Hollywood Cinema and Female Spectatorship. (New York and London: Routledge, 1994).
} 
transcendence along with the promise of visibility and recognition. The films play on nostalgia, invoking the image of older romanticised stars like Audrey Hepburn (also coded as a virginal Princess) in their storylines. Signs of class and becoming 'a lady' are therefore mapped onto the teen's transformed body. ${ }^{143}$ The made-over girl is possessed by a male character so the realms of possibility and desire inscribed on her body are more contained in terms of narrative and this is supposed to constitute her newfound maturity. In fact, the makeover can be seen as a foreshadowing of a loss of virginity in its similarities in terms of cultural meaning, although it is about marking an initially culturally unintelligible crossgendered body as desirable in order to prime it for a future sexual relationship. A virginal image like that of Britney Spears relies on Lolita connotations - a sexual promise based on the eroticising of a young girl that can never be fulfilled.

The virgin protagonist may be fetishised following her makeover, but she is also commonly understood to belong to a specific character and much is made of the fact that she has become more adult and her behaviour indicates that she will be the perfect mother someday. The character's image in 'real life' however, like Lindsay Lohan or Hilary Duff, may revolve around a state of being in-between girl and woman for some time, and similar Lolita connotations as was the case with Britney Spears. A movie has to end, while the appeal of a star in a certain simulated life-phase lasts much longer. The importance of virginity in popular culture images of teenagers and in fact the significance of virginity in a larger patriarchal framework can not be underestimated. In the makeover film, though the protagonist is often initially an object of disgust and not desired, her virginal status and corresponding inner purity is a key factor in her constitution as deserving of an idealised future - romanticised heterosexual love and a whole nuclear family. Sex for the 'slut' characters is not romantic - it is a means to possibly move up the social ladder; just another way to exercise control over their victims. The virgin protagonist is held up to be possessed by the male love

\footnotetext{
${ }^{143}$ Rachel Moseley explores how Audrey Hepburn conforms to classed and gendered notions of respectability in Growing up with Audrey Hepburn. (Manchester and New York: Manchester University Press, 2002).
} 
interest, which he symbolically does through the makeover, which objectifies her for his gaze while branding her as his construct or conquest. For instance in She's All That, the deviant female character leaves the idealised male in order to embark on an affair with a celebrity, while he is left to turn his attentions to the pure and virginal makeover protagonist, who we are to believe would never be swayed by such superficial temptations. The makeover is an act of 'love'- the male corrects the gender of the gender ambiguous adolescent, putting her in her rightful place. Like the Virgin Mary, the protagonist has an inner virtuous nurturant core prefiguring the idealised self-abnegating mother, and she is often partnered with a male who is worshipped in the school, almost in a religious manner.

If, as Susan Hopkins suggests, fame and success have replaced love and romance as an ideal prize for girls to achieve, then the teen makeover film has placed romance and heterosexual desire on the pathway as a necessary step in order to gain this recognition. The Disney-like virgin Princess is reaffirmed, triumphing over the girl power icon/avid consumer, (for textually the makeover film antagonist is both). The teen makeover film villain/girl power icon, while produced by patriarchy, has become drunk on the newfound empowerment her objectified body can afford her.

\section{Fears For the Modern Adolescent Girl in Society}

With the competing discourses surrounding female adolescence in the media, their every move judged and scrutinised and held up to be something their fans will passively copy, a moral panic has arisen from which claims are being made that young girls are being coerced into becoming sexual beings too early. Feminine consumer culture and the enjoyment of sexual agency may be celebrated in postfeminist texts featuring adult women, but there is an increasing fear of girls buying into the same consumer girl power oriented culture. While much public debate centres around the overtly sexual nature of music videos featuring female 
pop stars or on specific events, such as the Miley Cyrus photo scandal, ${ }^{144}$ there is increasing theoretical work being undertaken that displays fear for/of the adolescent girl, not only in terms of the effects of certain media images, but around the girling process in general - a process which many take for granted as a necessary rite of passage.

Of course, as shown earlier through the work of Angela McRobbie, the current climate is one where girls and women are being celebrated for a seemingly newfound dominance. Their involvement in the workplace gives them consumer power which is translated into their constructed image as powerful, active, desiring citizens. The process of girling therefore has been put up for debate as to what it currently means and what effect it has on young women in a postfeminist age. This section will look at some of the work that has been done in the area of female adolescence - how girls may be produced, what their influences are and how they are expected to behave in order to partake in society in the perceived best possible manner. I will cite work that identifies which adolescents are perceived to be 'at risk,' to use the term of Anita Harris, and why this might be. These studies into the realm of female adolescence help to provide a backdrop to the teen makeover film, which has an investment in the construction of femininity in order to secure the terms of heterosexuality, and yet these films are wary of how the construction of femininity has changed in a time where girls are told they can 'have it all.'

As I have indicated earlier, fears regarding the sexualised adolescent star and their consumers usually revolve around the signification of the girl power icon not the virgin star. It is important to remember that despite the intense focus currently being given to the sexualised address toward young girls recently, it has long been preferred in Western cultures that women are positioned as little girls, but that this

\footnotetext{
${ }^{144}$ In 2008, then 15-year-old Miley Cyrus appeared topless in a Vanity Fair photo shoot directed by Annie Leibovitz, causing a backlash by the Disney brand which owns the show Hannah Montana. The incident drew strong debate over whether the pictures should be construed as art or merely exploitative. http://www.nydailynews.com/gossip/2008/04/28/2008-0428_disney_miley_cyrus_blast_vanity_fair_mag.html (accessed: 28/07/2010).
} 
is rarely identified as the key problem. ${ }^{145}$ Valerie Walkerdine in Daddy's Girl: Young Girls and Popular Culture notes that the woman who is child-like is erotic, as the desired romantic partnership is between vulnerable child-women and their big Sugar Daddy protectors. She explains that lurking beneath the figure of the child-woman is the eroticisation of little girls. ${ }^{146}$ Walkerdine uses the 'Hey Mickey' video by Toni Basil, the film Annie (John Huston, 1982) and critical receptions of Shirley Temple films to illustrate her point. Rebecca Munford quotes Germaine Greer (The Whole Woman) as saying that;

'the propaganda machine that is now aimed at our daughters is more powerful than any form of indoctrination that has ever existed before... 'to deny a woman's sexuality is certainly to oppress her, but to portray her as nothing but a sexual being is equally to oppress her., ${ }^{147}$

Munford notes that, like Greer, many feminist theorists see girl power icons (and the consumer culture tied in with the slogan) as a 'depoliticised product of backlash rhetoric that harms those who buy into it., ${ }^{148}$

Rosalind Gill in Gender and the Media points to the sexualisation of culture with regard to newspaper stories, lads' mags, and even children's television. She notes that clothing companies target girls as young as five with midriff tops and T-shirts with sexually provocative slogans. The Playboy bunny icon is used on products targeted at the pre-teen market. ${ }^{149}$ Gill also, like Walkerdine, points to the girlification of adult women such as Kate Moss and Kylie Minogue, which she takes as evidence that the current media culture promotes female children as the most desirable sexual icons. ${ }^{150}$ It is necessary to call attention to the current sexualisation of culture for the very visible panic it has caused publicly and the

\footnotetext{
${ }^{145}$ Walkerdine, Valerie. Daddy’s Girl: Young Girls and Popular Culture. (Massachusetts: Harvard University Press, 1997). Pg. 155.

${ }^{146}$ Ibid. p. 155.

${ }^{147}$ Munford, Rebecca. 'Wake Up and Smell the Lipgloss: Gender, Generation and the (A)Politics of Girl Power.' In Third Wave Feminism: A Critical Exploration. Eds. Stacy Gillis, Gillian Howie, Rebecca Munford. (New York: Palgrave MacMillan, 2007). Pg. 267.

${ }^{148}$ Ibid. p. 267.

${ }^{149}$ Gill, Rosalind. Gender and the Media. (Cambridge: Polity Press, 2007). Pg. 257.

${ }^{150}$ Ibid. p. 258.
} 
theories and debates it has prompted. The media is saturated with a conflicting Madonna/Whore complex in regard to the adolescent star body. In combination with the cultural belief that children are innocent until corrupted, turning them from sugar and spice to soiled, sexualised and forever tainted, it is perhaps inevitable that some media texts seek to respond to these fears regarding the corruptible and corrupting pre-teen or adolescent.

It is my belief that, in part, the modern teen makeover film can be read this way. While makeover films in the past vary in terms of their depiction of villains, (although often there is a link in that they are usually rich, modern and fashionable), the female antagonists of the adolescent makeover film are overtly sexualised and obsessive about using their bodies and the bodily decoration their money affords them in order to control others. In contrast to the feminine passive and nurturing virtues present at the inner core of the protagonist, the antagonist characters represent a deviant corruption that is all too possible due to modern representations and discourses surrounding the active female citizen. The protagonist is celebrated for a seemingly greater mature outlook on life rather than her 'girlishness,' and yet she is rendered passive, ultimately in need of the protection an idealised heterosexual relationship will afford her. Of course in stating this, there appears to already be an obvious friction between the idea that girls are passive dupes of a media culture that seeks to sexualise and objectify them; that girls are sought to comply with postfeminist values of consumerism as citizenship that combines both an economic and corresponding sexual agency; or to echo Arthurs' argument, that feminine consumer cultures may alienate and replace men, leaving them to be treated as aesthetic temporary possessions that cannot ever really satisfy. I aim to introduce here that the teen makeover film is responding to fears regarding the sexualisation of girls in their construction of the villains to be punished in the narrative (although this does not always occur). I will show that the teen makeover film draws attention to the trouble of gender containment in patriarchal discourse, which it does in part by simultaneously 
promoting and condemning aspects of postfeminism as it seeks to construct the female gender ideal.

As I alluded to earlier, it is not only the sexualisation of girls that is provoking concern, although this may be seen as the primary threat in a more everyday public context. In the world of feminist theory, the very notion of becoming a girl, or becoming one's gender, has been under scrutiny for some time, and it is this process of girling that comes under great scrutiny in the films I will be analysing. As such, I will be discussing this at a greater length in later chapters. In a section that looks at fear for the adolescent however, it is important to bring attention to at least one specific work here that has looked at what is expected of the girl child in terms of gender performance. This will illuminate and set the scene for some persuasive theories regarding the ironic peril of the girl in today's postfeminist 'girls can do anything' culture. I will summarise the popular writing of Mary Pipher in order to introduce concepts of the surveillance and monitoring of the young girl - a matter of great importance to my analysis. It must be stressed that this is but an extremely small sample of work done in this area, (although this book had a particularly large impact with the public who made it a bestseller) - an area which has drawn a vast amount of interest from scholars who have looked at the issue from many different theoretical perspectives.

Psychiatrist Mary Pipher's Reviving Ophelia: Saving the Selves of Adolescent Girls was a highly successful best selling book written in 1994 that asked the question as to why so many adolescent girls were in therapy. Pipher hypothesises that she is seeing a lot of teenage girls in therapy because of the demands of the female role, which they are forced to comply with once they reach adolescence. Recounting a story about her own cousin, Polly, Pipher writes that in preadolescence, Polly was sporty, unrestrained, yelled orders and laughed with her mouth wide open. However, at junior high, Polly was called a tomboy and teased for not behaving like a lady, causing her to withdraw into a shell and then reemerge wearing fashionable clothing and exhibit new more traditionally feminine 
behaviours. ${ }^{151}$ Pipher calls this change in Polly's character a 'tragedy,' here denaturalising the girling process, drawing attention to it as something one must perform in order to partake in one's society without fear of bullying or ridicule. She agrees with Simone de Beauvoir's assessment of adolescence, who believed this life phase was a time when girls realised their only power came from 'consenting to become submissive adored objects. ${ }^{, 152}$ While Pipher conceives preadolescents to be able to act without worrying about gender role limitations, she notes that in early adolescence girls' maths and science scores plummet, they become less inclined to take risks and they become more self critical and deferential. ${ }^{153}$ Pipher places much blame on corporate America for casting young girls as sex objects in order to sell, for instance, jeans, believing adolescent consumers to often 'embrace the junk values of mass culture.' ${ }^{154}$ Appearance for young girls is hugely important in terms of defining social acceptability, ${ }^{155}$ and they model themselves after media stars rather than parental ideals. ${ }^{156}$ However, Pipher points out that girls are struggling with mixed messages - be beautiful but beauty is only skin deep; be sexy but not sexual; be honest but do not hurt anybody's feelings; be independent but nice; be smart but not so smart that you threaten boys. ${ }^{157}$ While Pipher sees adolescence to be the time when gender behaviour is stringently enforced, there are plenty of theorists who believe that gendering occurs much earlier than this.

Rosalind Gill in Gender and the Media notes for instance that it is striking that even magazines aimed at infants have 'remarkably polarised gender scripts: action, transport and adventure for boys and beauty, kindness and Princesses for girls. ${ }^{158}$ Interestingly, Pipher appears to occasionally believe in Reviving Ophelia

\footnotetext{
${ }^{151}$ Pipher, Mary. Reviving Ophelia: Saving the Selves of Adolescent Girls. (New York: Ballantine Books:

Random House Publishing Group, 1994). Pg. 17.

${ }^{152}$ Ibid. p. 21.

${ }^{153}$ Ibid. p. 19.

${ }^{154}$ Ibid. p. 23.

${ }^{155}$ Ibid. p. 40.

${ }^{156}$ Ibid. p. 38.

${ }^{157}$ Ibid. p. 35

${ }^{158}$ Gill, Rosalind. Gender and the Media. (Cambridge: Policy Press, 2007). Pg. 180.
} 
that while America today is a 'girl destroying place,' ${ }^{159}$ it was not so in the fifties. For instance, when Pipher recounts meeting enthusiastic well-adjusted adolescent Lori, she says that,

'Lori made me feel like I was in another place and time, back in the fifties in a home with plenty of money, happily married people and children who were not afraid or stressed...Lori was so well rounded and mentally healthy that I pondered how to explain it., ${ }^{, 60}$

Here, it would seem that Pipher is romanticising a pre-second wave feminist time, a time that while vastly different to today in terms of gender expectations, did straitjacket women in the passive, nurturing proud homemaker role. However, it is this role that can also be alluded to through the character of the protagonist, and is romanticised, in the teen makeover film.

In the teen makeover film becoming a gendered female is of the utmost importance for social acceptance and for future success. In postfeminist terms and in order to fit the construct of the future girl, who uses her economic independence in order to partake in consumer culture, one is encouraged to gain empowerment from a girly femininity. However, with fears regarding the delaying of motherhood and instability of the nuclear family, the performance of femininity in these films is also necessary in order to cement the terms of heterosexual desire, to objectify the female and encourage her to monitor her own body in accordance with cultural norms. Tellingly, while both female and male characters in these films are supposed to have 'learned something,' it is only the female protagonist who undergoes such a complete overhaul of appearance and behaviour.

In this chapter I have introduced the critical tools and methods I will use to study my chosen texts in the main body of analysis. I have also situated the teen makeover film within the context of the postfeminist times in which we live,

\footnotetext{
${ }^{159}$ Pipher, Mary. Reviving Ophelia: Saving the Selves of Adolescent Girls. (New York: Ballantine Books: Random House Publishing Group, 1994). Pg. 44.

${ }^{160}$ Ibid. p. 49.
} 
drawing attention to various postfeminist cultural icons and introducing how the teen makeover film may respond to these. The pop culture postfeminist icon is important in all her different manifestations, for there is not an obvious split between who appeals to young and old, no matter how much some might wish there were. These influences are crucial, for the makeover film seeks to mould, carve and manipulate characters in response to a complex cultural climate. It is important this climate is understood in order to identify where the real concern lies, and why the text seeks to sanctify and demonise who/what it does. 


\section{Chapter Two: The Female Adolescent in Space and as Sign}

Humiliated, laughed at and scorned by her peers, the female ugly duckling represents a common adolescent anxiety - exclusion. She is often the socially designated object of disgust, typically treated as a mere pawn to be discarded rather than as a living, breathing and feeling human being. She is often admirable as she retains a sense of quiet, passive dignity, a respect for others and a will to survive in an environment hostile to her - traditional idealised qualities of the feminine, reminiscent of the Cinderella characters in fables of old. The inner core of the presented-as-abject protagonist is commonly that of the good, hard-working and accepting girl, who prefigures the nurturing mother figure. ${ }^{161}$ The films want us to want her to succeed - for the hero figure to break through the threat that she unintentionally poses to the social order and help her gain the social status that the morality of her character seemingly so deserves. ${ }^{162}$ The films I will discuss here include 10 Things I Hate About You - a teen re-make of Shakespeare's The Taming of the Shrew in which a group of teenage boys conspire to get Kat Stratford (Julia Stiles) an angry non-conformist, to date so that they can get to her popular younger sister Bianca (Larisa Oleynik). It is a rule of the Stratford sisters' possessive father that Bianca can only date when her sister does. I will also look at She's All That - an update of the Pygmalion tale in which high school athlete Zack (Freddie Prinze Jr) accepts a bet that he can make any girl Prom Queen with the right hair and make-up, even the 'scary and inaccessible' Laney Boggs (Rachael Leigh Cook). The Princess Diaries tells the story of a socially awkward teenage girl who discovers that becoming a Princess is her birthright, and $A$ Cinderella Story retells the fairytale in a high school setting where the protagonist Sam (Hilary Duff) remains enslaved by her stepmother and frustrated that she is invisible to the boy of her dreams. These films I will discuss in depth at times where I think a deeper analysis is conducive to the argument, and I will also refer from time to time to other teen films, namely Never Been Kissed (Raja Gosnell,

\footnotetext{
162 Thomas E. Wartenberg discusses the importance of the tale of Cinderella as moral rectification in Unlikely Couples: Movie Romance as Social Criticism, (Colorado: Westview Press, 1999), Pg, 74.
} 
1999), which although it does not feature a teen protagonist, stars Drew Barrymore as an undercover reporter who while researching a story at a local high school is allowed to reclaim and remake her traumatic adolescence.

In this chapter I will analyse how the viewer is introduced to the female protagonist of the teen makeover film through the immediate signifiers at the site of her body, her bodily movement and relationship to domestic space. While it is important that the protagonists are female, given the significance of these films amid wider concerns regarding postfeminism and female adolescence discussed in Chapter One, they are presented here as not being identifiably of their sex and supposedly natural gender, allowing the films to construct them as malleable beings which can be moulded, shaped and thus corrected to create an ideal feminine. This is not to say that these girls constitute an unthreatening base on which to create an attractive watercolour, rather they transgress gender boundaries and display signs of behaviour usually reserved for the masculine side of the gender binary that cements heteronormativity. They slip and slide between masculine and feminine. However, because the girl is not usually complicit in her gender transgression and is wounded rather than proud as a result of her outcast status, there are vulnerable layers to her that can be symbolically penetrated by a male agent or 'magic wand' bearing fairy godmother figure whose magic works in order to benefit patriarchy. The breaking away of the abject layers exposes this inner passive core which is the ticket to romance, family, and ascension up the social scale - superiority. The correcting of the female adolescent does not usually run smoothly, presumably we are to believe because she is initially unaware that the changes are for her own good, and so therefore there is a struggle for this heteronormative soul at a corporeal and discursive level with undertones regarding societal views on sexual ethics and morality.

I intend to show that these characters are constructed as abject beings due to their lack of conformity to the rules of gender within a white patriarchal culture, and that the cause of this portrayed gender confusion is shown to be their upbringing 
within a non-nuclear family, whether it be through a relationship to a father that prevents cultural exchange taking place, (the more common scenario), or to a narcissistic mother, who has failed to give up her subjectivity for the welfare of the child, thus thwarting her development. My hypothesis that the key female character is presented as abject and in need of guidance through her state as 'being' rather than 'human' is strongly influenced by the theories of Judith Butler and Julia Kristeva.

Judith Butler points out that it is the concepts of sex, gender and sexuality that assures and stabilises one's identity, and that the very concept of the person is called into question when one emerges who does not conform to the 'gendered norms of cultural intelligibility by which persons are defined. ${ }^{163}$ If, then, one emerges who does not conform to these sex and gender rules, they could perhaps be termed as abject. Kristeva terms abjection as that which does not respect borders, positions, or rules, and so therefore disturbs identity, system and order. ${ }^{164}$ The abject is the place where there is a collapse of meaning - it is a threat to life and therefore must be excluded. Kristeva has pointed out, however, that it is necessary that the abject be tolerated, for while it does threaten to destroy life, it also helps to define life - 'the activity of exclusion is necessary to guarantee that the subject takes up his/her proper place in relation to the symbolic. ${ }^{\text {, }}{ }^{25}$ Abject things highlight the fragility of the law, existing on the other side of a border which separates the living subject from that which threatens its demise. The subject, which is constructed in and through language, through a desire for meaning, is spoken by the abject, the place where meaning collapses. ${ }^{166}$

It is my belief that many of the female protagonists of the makeover text become unintelligible to other characters through their ambiguous, cross-gendered state a state that threatens to prevent the protagonist's entry into an institutionalised

\footnotetext{
${ }^{163}$ Butler, Judith. Gender Trouble. (New York: Routledge, 1990). Pg. 23.

${ }^{164}$ The abject is explored by Barbara Creed in The Monstrous-Feminine: Film, Feminism, Psychoanalysis. (London: Routledge, 1993). Pg 8.

${ }^{165}$ Ibid. p. 9.

${ }^{166}$ Ibid. p. 10.
} 
heterosexual system. On the one hand they are clearly female in a biological sense, although their behaviours demonstrate an unintelligible mix of masculine and feminine gendered characteristics that render them confused, ineffectual, and designated for failure in a social and sexual sense. They are seen as abject as they have not learned the rules of gender performance and therefore cannot be said to be clearly of their sex. These characters are expelled from the social body within the school, and yet serve to highlight the power of those within the symbolic order, (although as I will examine in Chapter Three, Deviant Teens, the hierarchy within the school itself is portrayed as flawed as it has been tampered with and manipulated by deviant female characters). The narrative then portrays these adolescents as in need of correction so they can participate in a 'normal' and fruitful adulthood. In this chapter I would like to explore how the protagonist is initially presented or set up in the text and the alluded reasons for this.

\section{The Physical Presentation of the Female Adolescent}

In the makeover genre, the candidate to be reinvented is often presented as recognisably in need of help to the viewer through a set of familiar filmic codes. These codes are predominantly present as signifiers at the site of the literal body in question, and are recognisable due to their continual deployment in the genre, beginning with Now Voyager in 1942. Elizabeth Ford and Deborah Mitchell have loosely, yet fittingly, termed these physical traits 'Hollywood ugly signifiers,' and go on to list what these are, including glasses, no makeup, heavy brows, heavy dark hair, dumpy figure, poorly fitting, unstylish clothing and thick stockings. ${ }^{167}$ They note that appearance for Now Voyager's protagonist Charlotte Vale (Bette Davis) becomes an indicator of entrapment, not merely a series of fashion mistakes. ${ }^{168}$ In the films studied here, we can see copies of the Charlotte Vale archetype most clearly in She's All That and The Princess Diaries. Protagonists Laney Boggs and Mia Thermopolis (Anne Hathaway) both have the heavy thick dark hair and brows and hide their newly reproductive bodies under shapeless

\footnotetext{
${ }^{167}$ Ford, Elizabeth A and Mitchell, Deborah C. The Makeover in Movies. (North Carolina: McFarland \& Company Inc, 2004). Pg. 11.

${ }^{168}$ Ibid. Pg.14.
} 
clothing that rejects the male gaze. The dark hairiness of many of the female protagonists and their slightly curved posture does invite comparisons to a specific creature of mythology - the werewolf. In fact, in The Princess Diaries, beautician Paolo (Larry Miller) refers to Mia’s hair as being wolf-like. The werewolf has a specific relationship to the female adolescent in that in many hormonal teen horrors it is the event of first menstruation or sexual experience that marks a teen's metamorphosis into the monster. ${ }^{169}$ Bianca Nielsen in her essay on werewolf film Ginger Snaps, writes that during Ginger's lycanthropic transformations, she persistently refuses to obey the gendered laws of her small Canadian town. Because Ginger refuses to comply with the norms of her culture, she appears to be heading for self-annihilation. ${ }^{170}$ Similarly, the female protagonists symbolising the werewolf state in the teen makeover genre also do not comply with gender norms. This is not an outright refusal on their part, (with the exception of Kat Stratford in 10 Things I Hate About You), but rather due to the fact that they do not know any better. The symbolism of the werewolf then further indicates that the female protagonist is gender confused, in need of guidance to be freed of her outward association with the monstrous and abject, that which transgresses boundaries.

The fact that werewolf transformations are often presented as being synonymous with puberty operates as a visual indicator that the female character is dangerous and must be contained urgently before this state is allowed to progress/continue. Inside the cross-gendered confused girl, is an idealised version of white womanhood - beautiful, passive and nurturing - waiting to be freed. She is initially perceived as a threat to be contained, but because of her lack of agency in the creation of herself as a threat and her lack of awareness as to how to correct herself, she leaves her body wide open for re-signification. It is the deviant female characters in the text, the girls who rule the space of the school in packs and who

\footnotetext{
${ }^{169}$ Nielsen, Bianca. “ 'Something’s Wrong, Like More than You Being Female:’ Transgressive Sexuality and Discourses of Reproduction in Ginger Snaps” in Thirdspace. (v3, issue 2, 2004). Pg 2.

${ }^{170}$ Ibid. p. 4.
} 
masquerade as fetishised objects for the male gaze who are the real castration threats.

\section{The Female Adolescent and an Association with the Mind}

Both Mia in The Princess Diaries and Laney in She's All That, like Charlotte Vale in Now Voyager, wear glasses, which are absent by the conclusion of the film. Glasses, which are symbolic of intellect, are important here, associating the protagonist with the mind. This is not to suggest that these protagonists are not threatening in their initial bodily state, for they certainly are, but that this gender confusion manifested in their appearance and behaviour can also be read through their association with the cerebral. Laney spends much of her time painting political works, and Mia, while not being identified as overtly intellectual herself is associated with the mind through her best friend Lily (Heather Matarazzo), who is deeply interested in environmental causes, and who is very influential over Mia’s character. The glasses worn by these characters disappear as their participation in these activities is channelled into a more suitable direction or is stopped altogether. It is important to explain here why a female connection with the mind is construed as threatening by other characters in terms of theories of whiteness. These texts are about performing idealised white femininity after all in order to create white, middle class nuclear families. As Sarah Hentges has noted, a characteristic of mainstream teen films is how whitewashed they are, with only a skin deep inclusion of other races, ethnicities and cultures. ${ }^{171}$

Richard Dyer has explained the struggle between mind and body in relation to whiteness, noting that it is spirit, aspiration and awareness of the highest reaches of intellectual comprehension that is held to distinguish whites. ${ }^{172}$ However, this is only true of white males, with the model for white womanhood being the Virgin Mary, a 'pure vessel for reproduction who is unsullied by the dark desires that

\footnotetext{
${ }^{171}$ Hentges, Sarah. Pictures of Girlhood: Modern Female Adolescence on Film. (North Carolina: McFarland \& Company Inc, 2006). Pg 19.

${ }^{172}$ Dyer, Richard. White. (Oxon: Routledge, 1997). Pg, 23.
} 
reproduction entails. ${ }^{173}$ Mind controls body, and it is the female who fulfils the negative quotient of the binary when this is applied to gender. The tragedy of the white female protagonist here lies in the fact that she is unable to fulfil her destined place in an idealised nuclear family because of the disgust she provokes in other characters, with a masculine over association with the mind being only one, (albeit an important one), reason for why she is constantly labelled a freak by her peers.

Although this study will not look in depth at the male characters in the text, it must be here noted that the male character in the teen makeover film is also at risk of being associated on the 'wrong' side of the mind/body binary. Often the male love interest is endangered by his association with hard-bodied masculine characters who have fallen slave to the dark desires of the body. ${ }^{174}$ It is the love of the female character, who becomes beautified and romanticised for his gaze, that inspires the male to lead a life of the mind that he has secretly desired (as in $A$ Cinderella Story), or has to learn to re-value after a brief period of corruption (She's All That). Sometimes this character is identified as waste, merely body, to be discarded by the new and improved female protagonist for a better suitor, (Never Been Kissed, The Princess Diaries).

\section{Borderless without Physical Markers of Abjection: A Study of 10 Things I Hate About You and A Cinderella Story.}

It must be noted here that not all the female protagonists studied here carry the full regalia of Hollywood ugly signifiers. In the cases of Kat in 10 Things I Hate About You and Sam in A Cinderella Story, the physical markers of their borderless state are more subtle. Links to the monstrous are physically not evident on the bodies of these two adolescents. Instead, signs are utilised that emphasise a connection with the masculine, which becomes threatening to their designated sex role as women.

\footnotetext{
173 Ibid. P. 29.

${ }^{174}$ Richard Dyer discusses dark desires as being a struggle for the white man in relation to the agony of Christ, who was fully flesh and fully spirit. White. (Oxon: Routledge, 1997). Pg. 28.
} 
Kat Stratford is one of the most interesting protagonists of the teen makeover film as she is the character out of all those studied here who inspires the most revulsion and fear from her peers. She too is associated with the mind, but her intelligence is of a greater threat than the others, for she has channelled her intellectual leanings into feminism. She performs aspects of aggressive masculinity in order to further a feminist agenda. While Kat is an active and willing agent in constructing her cross-gendered state, which she sees as a form of empowerment, it is important to note that an inner core or a 'past Kat' is mentioned by her sister Bianca. Bianca tells Cameron (Joseph Gordon Levitt) that Kat used to be really popular and then one day seemed to get sick of it - Kat was once a 'normal' teenager before she went bad. While the text does not seek to create a Bianca-like figure out of Kat, the idea seems to be that once Kat was social and fun-loving rather than antagonistic and angry, and can be closer to this way again once some taming has taken place.

Kat's heteronormative soul is still there to be reclaimed, but it has been willingly repressed which makes the job a little tougher. Her feminism ceases to take centre stage however once Patrick (Health Ledger) has succeeded in breaking down her hostile barriers. The love between them begins to grow after Kat displays vulnerability and a need to be protected by Patrick after getting drunk at a party after she exhibits a more passive 'feminine' self. The initially angry feminist Kat challenges the education system, which she labels 'oppressive and patriarchal,' in English class, where she demands of Mr Morgan (Daryl Mitchell) to know why the students can't be given books written by feminist authors such as Sylvia Plath, Charlotte Bronte or Simone de Beauvoir as an alternative to Shakespeare. The film is based on Shakespeare's The Taming of the Shrew, so here it is indicated that Kat is rebelling from the text that has produced her. Kat is further identified as a feminist when the characters of Cameron and Michael (David Krumholtz) inform Patrick, who they are trying to convince to date Kat, that she likes feminist prose and angry girl music of the Indie rock persuasion. Here the words feminist and angry are used in quick succession, presenting a parallel to viewers of the two 
terms. Kat's feminism also problematically serves to portray the fact that she is a man hater, (for instance she labels all the boys at her school 'unwashed miscreants'). Even more problematically, her man-hating ways lead Cameron to conclude at one point that she must be a lesbian, which shows how Kat's behaviours are seen to not fit with the rigid heterosexual system. She is seen as anti-social, weird, atypical - a real challenge to conformity.

It is obvious in the text that Kat is reviled and feared by the student body - the guidance counsellor Ms Perky (Allison Janney) tells Kat that students think she is a 'heinous bitch' and then mentions that Bobby Ridgeway's testicle retrieval operation went quite well. Here Kat is set up as quite a literal castration threat. Kat has involved herself in a redefinition of the feminine, a task she finds herself to be alone in. However, the physical signing of Kat's body when we are first introduced to her is symbolic of an aggressive masculinity. When we first see her, she wears army combat print and cargo trousers - signifying war, aggression, a desire to fight, (and an ability to fight too it seems from what we learn of Bobby Ridgeway's predicament). By the conclusion of the film, the army print has been abandoned in favour of a blouse and skirt. It may be tempting then to read the initial Kat as a phallic woman, however as Barbara Creed points out, the phallic woman is commonly a reassuring figure of sexual sameness, ${ }^{175}$ supposedly representative of the woman's whole state before she was castrated, and Kat certainly is not reassuring, she is terrifying. She is a female castration threat who uses symbols of masculine power in order to dominate, thus using gender borderlessness to her advantage. She is associated with a masculine hard body ${ }^{176}$ when the antagonist of the film Joey (Andrew Keegan) refers to her style as a 'Rambo look.' Joey also tells Kat this look is dated, from which we can perhaps infer, along with Mr Morgan’s comments, that Kat’s militant feminism on the

${ }^{175}$ Creed, Barbara. The Monstrous Feminine: Film, Feminism, Psychoanalysis. (London: Routledge, 1993).

${ }^{176}$ Jeffords, Susan. Hard Bodies: Hollywood Masculinity in the Reagan Era. (New Jersey: Rutgers University Press, 1994). 
whole is dated and unnecessary, as was the masculine hard-bodied ideal going into the nineties. ${ }^{177}$

Another protagonist who does not wear Ford and Mitchell's Hollywood ugly signifiers is Sam in A Cinderella Story. In contrast to the other adolescents studied, Sam is not perceived as such a great object of disgust because she does not know the rules of gender performance, although her character is socially excluded. Sam is played by Hilary Duff, who already had a strong fan base from her Disney television series Lizzie McGuire before going into this film. The audience already knows that Lizzie/Hilary/Sam is of good moral character, and while she may face problems in school life she will always make the right decision that will benefit her in the end. ${ }^{178}$ There is even a board game What Would Lizzie Do? that requires fans to guess Lizzie's response to certain problematic situations. It would have perhaps have been risky to mark Duff as physically abject at the opening of the film when her image, and all the merchandise tied in with her image, relies on her blonde all-American bubbly girl persona. Duff's learning of femininity in this film reinforces her status as the Disney Princess her audience knows she is.

It is the fact that Sam has, by her own admission in the narration, been 'left behind in the makeup and fashion departments' that leads to her invisibility in the eyes of her love interest Austin (Chad Michael Murray). Sam is, once again, associated with the mind - the only reason, we are to believe, that she puts up with her stepmother so passively is that she needs the money from her diner job in order to attend Princeton University. Early in the film however, Sam's father tells her that Princes attend Princeton, conflating the two, so we could infer that Sam's fixed and helpless position brands her a damsel in distress, leading to her discovery by a

\footnotetext{
${ }^{177}$ Jeffords, Susan. 'The Curse of Masculinity: Disney's Beauty and the Beast.' In From Mouse to Mermaid: The Politics of Film, Gender and Culture. Eds: Elizabeth Bell, Lynda Haas and Laura Sells, (Indiana: Indiana University Press, 1995). Pg 161.

${ }^{178}$ Richard Dyer discusses the perception that the film roles of stars in some way reflect their true personalities in Stars. (London: British Film Institute, 1998). Pg 20.
} 
Prince, whose aid she needs in order to attend Princeton, where the Princes go - a destination to a heteronormative utopia.

Sam's name is clearly an ambiguous one in terms of gender - she is also strongly associated with the masculine in terms of her love of baseball. At the beginning of the film, Sam wears dark, shapeless clothing and a baseball cap often pulled down low over her face - the latter signifies her regression into herself, as the cap stops people from interpreting facial emotive signifiers, and also her attachment to her dead father, who taught her to play the sport. Sam's prowess in baseball is actually admired by Austin on one occasion, but importantly he does not realise her as a potential love interest, and she cannot escape her stepmother's clutches, until she puts on a dress... a wedding dress no less. This transformation to regal Princess at the ball, the performance of an idealised femininity, is what is needed for Sam to change her destiny.

\section{The Female Adolescent's Bodily Comportment and Relationship to Space}

It is not only the physical signing of the body with links to the masculine and the mind that aid in the construction of the female as an abject and cross-gendered being. Each of the female protagonists studied is shown to have a problematic relationship to space in terms of their navigation of it and objects in their path. Many of the adolescents seek solace in a marginalised domestic space, perhaps an attic (The Princess Diaries, A Cinderella Story) or a basement (She's All That). These spaces typically are dark, signifying the need for the adolescent to be 'enlightened,' and shadowy, emphasising the fact that the girl is hidden, waiting to be discovered.

Attics and basements in the teen makeover film are spaces where the adolescents retreat from the public eye. They are spaces where they may engage in wayward hobbies without fear of ridicule. Laney in She's All That uses her basement to paint her artworks, while Sam in A Cinderella Story retreats to her room to read all her mail from Princeton, which she sees as the only potential escape from her 
horrible existence. The fact that Mia lives in an attic where the only way out is by scaling down a pole is indicative of her alternative way of living, which has been imposed on her by her mother. These spaces in some ways define a female madness - here, the adolescent can unapologetically live out her undesirable lifestyle without fear of scrutiny. ${ }^{179}$

However, these are also spaces where the audience becomes privy to the characters' real emotions - the vulnerability behind the defiant façade. Although the adolescent may be defined as freakish by other characters in the text due to her failure to perform an intelligible femininity, these dark, enclosed spaces help to redefine the adolescent as closer to the literary 'angel of the house'. Mia, Laney and Sam run to these sanctuaries to be alone and to contemplate the outside world after they have been wounded by it. Blame is not placed on others, but rather inflected inward, the adolescents displaying misery at their own inability to lead more fulfilled lives. Makarie’s Wilhelm Meister's Travel's provides a description of the angel of the house as follows: 'she leads a life of almost pure contemplation without external events....she shines like a beacon in a dark world...she is a model of selflessness and purity of heart. ${ }^{180}$ The attic/basement may be initially a sanctuary for the power of creativity, seen as a form of male mimicry, but this signification becomes overridden as the adolescents are shown to retreat further into these spaces to the detriment of their happiness. Intervention in the life path of these characters is necessary in order to eclipse the need for these areas, which are places of retreatism, alienation and sometimes self-loathing.

Commonly, the adolescent is shown to have a blindness in relation to space and is therefore clumsy. We laugh as Mia in The Princess Diaries plows her scooter straight into her neighbour's trash cans, when she hits her head on the roof of her

\footnotetext{
${ }^{179}$ Sandra Gilbert and Susan Gubar note that female writers were often defined in the nineteenth century as mad and monstrous for failing to apologise for their literary efforts, which were seen as a form of male mimicry. If they did not behave like angels in every way, they then therefore had to be monsters. The Madwoman in the Attic: The Woman Writer and the Nineteenth Century Literary Imagination. (New Haven and London: Yale University Press, 1979). Pg 63-66.

${ }^{180}$ Ibid. p. 22.
} 
limo and when she accidentally breaks Queen Clarisse's valuable statue. We grimace as Josie Gellar from Never Been Kissed traps her scarf in the car door whilst wearing it and then proceeds to spill chocolate milk on her white trousers in front of a cafeteria full of students. Kat from 10 Things I Hate About You deliberately runs into people in order to keep her aggressive image - tellingly, she often uses her car, a phallic symbol of mastery to intimidate. It is she who screams obscenities out of her car window at Michael when he drives in front of her, who is infantilised in comparison by riding a scooter complete with bell and front basket. She then crashes into Joey’s car, which he has strategically parked in order to block her from exiting a parking space. In both cases Kat has situated the male character as an object in space, while she is the navigator. Sam in A Cinderella Story is not clumsy, but characters do trip over her due to her invisibility, (this also happens in The Princess Diaries as Mia notes when she complains to Lily, 'someone sat on me again'). While phenomenologists have convincingly argued that a lack of mastery of space lies in acquired feminine body comportment, I will illustrate that these films oppositely and problematically present performed femininity as a key to empowerment, however misleading this may be. First it is necessary to briefly explore some of the work in phenomenology that has been done in this area.

Vivian Sobchack has described her feelings of being lost in space as gendered. She discusses her purposeful sense of direction as a child and her increasing feelings of being lost as an adult - 'negotiating unfamiliar worldly space is for me frequently an anxious state, always mutable and potentially threatening. ${ }^{181}$ She notes that male identity depends on the sense that they can get about in the world on their own, citing the common male reluctance to ask for directions;

'Being a master of the universe presumes an existential relationship and reciprocity with space that is centered in, tethered to and organised contiguously

${ }^{181}$ Sobchack Vivian. Carnal Thoughts: Embodiment and Moving Image Culture. (Berkeley and Los Angeles: University of California Press, 2004). Pg. 15. 
around one's embodied intentionality and its perceived possibility of realising projects in the world.' ${ }^{182}$

Sobchack notes that it is because women are more often objects of gazes that locate and invite their bodies to live as material things immanently positioned in space rather than as conscious subjects with the capacity to transcend immanence, that they cannot negotiate space as well as their male counterparts. ${ }^{183}$ It would then seem that the tendency of the female protagonist to collide with objects and people is a result of her gendered state - female. And it is true, that once the female adolescent is beautified and paired with a male love interest, a 'map maker' or 'tour guide,' she begins to navigate space in a much more fluid manner. However, my work in this chapter depends on the notion that the female protagonist is an abject thing, cross-gendered, but able to be moulded. Her threat lies in an over-association with the masculine - powers that in the hands of the feminine constitute a threat.

Iris Marion Young locates woman’s ambiguous transcendence (a transcendence overlaid with immanence), inhibited intentionality (a severing of the relationship between aim and enactment), and discontinuous unity (a tendency to locate motion in part of the body only, leaving the rest immobile) in feminine comportment, ${ }^{184}$ which derives from woman's experience of her body as thing as well as a capacity. ${ }^{185}$ Marion Young uses Simone de Beauvoir's The Second Sex in order to illustrate that human existence is defined by social, cultural, historical and economic limits of situation, denying the notion that differences in behaviour and psychology between men and women are a result of natural essence. ${ }^{186}$ Marion Young observes that women are not as open with their gait and stride as men and sit with their legs closer together. Women tend not to put their whole

\footnotetext{
182 Ibid. p. 32.

${ }^{183}$ Ibid. p. 32.

${ }^{184}$ Young, Iris Marion. On Female Body Experience: Throwing Like a Girl and Other Essays. (New York: Oxford University Press, 1995). Pg, 38.

${ }^{185}$ Sobchack Vivian. Carnal Thoughts: Embodiment and Moving Image Culture. (Berkeley and Los Angeles: University of California Press, 2004). Pg 33.

${ }^{186}$ Young, Iris Marion. On Female Body Experience; Throwing Like a Girl and Other Essays. (New York: Oxford University Press, 1995). Pg 29.
} 
bodies into engagement in a physical task with the same ease and naturalness as men. ${ }^{187}$ She convincingly illustrates her idea that women in a sexist society are physically handicapped, and that we learn to live out our existence in accordance with an assigned patriarchal definition. ${ }^{188}$

Marion Young locates the source of feminine bodily existence in the fact that girls and women are not given the opportunity to use their full bodily capacities in free open engagement with the world, for instance girls are less encouraged to play sport and girls' play is often more enclosed than the play of boys. ${ }^{189}$ She describes a specific style of feminine body comportment and movement, which is learned as the girl comes to understand her gender. She acquires habits - to walk, stand, sit, gesture, like a girl - thus hampering her movements. 'The more a girl assumes her own status as feminine, the more she takes herself to be fragile and immobile, and the more she actively enacts her own body inhibition. ${ }^{190}$

Sobchack and Marion Young, therefore, see a direct relationship between performed femininity, the immanence of the female body and a poor negotiation of wordly space. Woman can not master space because she is taught to treat her body as thing, as object rather than capable subject. The teen makeover film however, would seem to tell a different story. In these stories, it is the being that is ambiguously gendered who can not negotiate space fluidly. Interestingly, the female protagonists, while embodying some of Marion Young's feminine body traits, also in many cases enact masculine body comportment in their open gait, splayed legs and general lack of 'feminine grace.' The lack of performed feminine body comportment is clearly a turn-off to male characters in the texts. Witnessing Kat's aggression on the soccer field prompts Joey to offer Patrick more money to take her out in 10 Things I Hate About You. In She's All That, Laney is picked as the candidate for a bet by Dean (Paul Walker) after he witnesses her trying to pick

\footnotetext{
${ }^{187}$ Ibid. p. 33.

${ }^{188}$ Ibid. p. 42.

${ }^{189}$ Ibid. p. 43.

${ }^{190}$ Ibid. p. 44.
} 
up dropped books in a most unladylike manner - legs and arms splayed, creating quite the unwelcome spectacle. Clearly such an ungainly creature could never fulfil the criteria for Prom Queen, we are to believe. The films, jarring with the theories of Marion Young and Sobchack, present the idea that performed femininity, along with the idealised heterosexual relationship this will bring, is the key to cure the body's flawed navigation of space (whether this be through discontinuous unity and ambiguous transcendence of the key adolescent, an antisocial or discourteous use of space or through the failure of other subjects to locate the protagonist in space at all), which in the makeover film is not synonymous with the feminine, but with the abject - that which crosses borders and highlights the fragility of system and order. Here of course, the abject is one who is not gendered specifically in accordance with their sex, a state which the makeover promises to cure.

Performance of the feminine and the pleasures of objectification this brings is presented as a means to greater control and mastery over one’s bodily movements, putting one on the path of the 'straight and narrow.' It is visibility, granted through idealised beauty, that grants one the power to make a difference - be it in their own lives or the lives of their loved ones. Mia in The Princess Diaries undergoes a makeover in which she is beautified, but she is also taught to eat in a more feminine manner through the use of restraining scarves and to take the passive position when learning the waltz. After this makeover, she is able to hit a baseball, score a home run and pass gym class. Learning the rules of gender gives her confidence and the ability to supposedly take charge. Kat in 10 Things I Hate About You, after the experience of falling in love ceases her aggressive use of space, is granted happiness and peace with her past as a result. Laney in She's All That, seemingly magically as a result of her beautification, no longer trips and falls. Instead she is watched in awe as she moves through space in a more dignified and feminine manner. The female character as a result of a makeover gets greater access to space within the narrative, as well as the promise of upward social mobility. 
Gender Confusion as a Result of Nuclear Family Breakdown: Single Fathers, Single Mothers and Wicked Stepmothers.

If these films imply that the adolescents' fractured negotiation of the filmic world and their immanence in marginalised domestic spaces is a result of their crossgendered being and therefore an inability to participate in a society built on institutionalised heterosexuality, what then is the cause of their supposedly tragic state? It may be possible that an underlying suggestion in these films is that the protagonist has shunned femininity because of what it now signifies in an age of postfeminism, however a much more pronounced and investigated reason in these narratives is that the female protagonist comes from a broken family, which has seemingly stunted her normative development as she has not been taught the rules which would allow her to succeed in life.

Sar Levitan, Richard Belous and Frank Gallo in What is Happening to the American Family? quote Freud in writing that families are the germ cells of civilisation, commenting that social critics are warning of a 'virulent disease' which threatens these cells. ${ }^{191}$ The authors lament the fact that even conservative national political climates have not recreated family stability, ${ }^{192}$ and note that along with emerging new family structures and sexual freedoms there is a growing list of problems with ominous implications for American society. ${ }^{193}$ The authors appear nostalgic for a time when the husband was in the workforce, there was a full time housewife at home and several children to carry out reproductive heterosexuality. Although careful not to appear scathing of the women's rights movement, the authors continually draw parallels between women's freedoms and the breakdown of the family, worried about female-headed families in particular 'women and children first, a chivalrous precept in days gone by, assumes a grotesque meaning when it is applied to the widespread destruction among

\footnotetext{
${ }^{191}$ Levitan Sar, Belous Richard and Gallo Frank. What's Happening to the American Family? (Baltimore and London: The John Hopkins University Press, 1988). Pg, 8.

${ }^{192}$ Ibid, p. 7.

${ }^{193}$ Ibid. p. 9.
} 
female-headed families. ${ }^{\text {,194 }}$ They fear that if the family is not a valued institution, that society may not be sustained, the next generation will not be socialised and basic values and norms will not be passed down to children - 'the products of broken homes will carry their scars first to the school system and then on to other social institutions. ${ }^{195}$

The authors believe the top priority should be the prevention of births to unmarried women, ${ }^{196}$ therefore advocating the position of celibacy until marriage. In Farewell to the Family? Public Policy and Family Breakdown in Britain and the USA, Patricia Morgan is primarily concerned with the fact that family policy is designed for the lone parent, with the burden of taxation shifted to married parents. ${ }^{197}$ Morgan writes that 'all societies that have survived have been built on marriage, and children have always been raised within traditional families.'

Morgan accuses 'feminist demonology' of circulating the idea that male rights and responsibilities in relation to children are the expropriation of women's bodies within kinship, marriage and inheritance. She compares this notion to the work of Friedrich Engels, who saw early stages of human history as times of promiscuity and communal provision where no children knew their fathers. ${ }^{198}$ Sarah Chacko's article 'Family Breakups Costly: Promoting Healthy Marriages Touted as Remedy' discusses the high divorce rate in Louisiana and the poverty of children who live in single parent homes. She quotes Gene Mills, Executive Director of the Louisiana Family Forum, which promotes traditional family values, as saying policy must be introduced to ensure people stay in marriages for longer. ${ }^{199} \mathrm{Jim}$ Wooten's article 'Put Families First, One Father at a Time' states that 'life without a mother and father is the rankest cruelty self-absorbed adults can inflict

\footnotetext{
194 Ibid. p. 10.

${ }^{195}$ Levitan Sar, Belous Richard and Gallo Frank. 'Chapter One: Family Matters.' What's Happening to the American Family? (Baltimore and London: The John Hopkins University Press, 1988). Pg, 6.

${ }^{196}$ Ibid. p. 207.

${ }^{197}$ Morgan, Patricia. Farewell to the Family? Public Policy and Family Breakdown in Britain and the USA. (London: Institute of Economic Affairs Health and Welfare Unit, 1995). Pg 1.

${ }^{198}$ Ibid. p. 152.

${ }^{199}$ Chacko Sarah. 'Family Breakups Costly: Promoting Healthy Marriages Touted as Remedy.' Advocate. (Aug 23 2008). Pg 10.
} 
unintentionally.' He questions why women would create human life with men they do not view as marriageable. He quotes Professor Jeffrey McCall as saying that reality programmes demean the institution of marriage and seem intent on redefining how marriage is viewed in America. ${ }^{200}$ These books and articles sourced here then display hysteria at the continual disintegration of patriarchal nuclear families, and apportion much of the blame to feminism, or in Wooten's case to the fact that women seem unable to choose ideal partners that will result in family stability. These articles are written from a conservative perspective, this is true, but given the current societal fears for the adolescent and the pressure on girls and women to delay motherhood in order to participate in consumer citizenship, I do believe that teen makeover films cater to conservative viewpoints. Importantly, there is a clear fear manifested in these articles that the breakdown of the nuclear family will lead to future generations lacking in basic values and norms. This fear also manifests itself in the teen makeover film.

In most cases, the adolescent has a single father (10 Things I Hate About You, She's All That, and also Clueless, Amy Heckerling, 1995, and Wild Child). This is usually the result of the mother's death which prevents any nasty questions over subjectivity of the mother or feminism being raised. The situation paves the way for an incest scenario in which the protagonist takes on a mothering role, so intent on nurturing and/or controlling other members of the family that she fails to be the object of cultural exchange from the father. Cited in Cowie, Levi Strauss has argued that the exchange of women is the constant term in all kinship structures which are a system of exchange and communication. ${ }^{201}$ Cowie notes that kinship is a structure where men and women are put in place through complex rules of familial affiliation. ${ }^{202}$ The incest taboo is then a misuse of language in this system of communication - a misuse that places social relations in jeopardy. ${ }^{203}$ In film genres targeted at teenage girls, Kathleen Rowe Karlyn has pointed out that the

\footnotetext{
${ }^{200}$ Wooten, Jim. 'Put Families First, One Father at a Time.' The Atlanta Journal. (April 21, 2009). Pg 8.

${ }^{201}$ Cowie Elizabeth. 'Woman as Sign.’ In Feminism and Film. Ed. E. Ann Kaplan. (New York: Oxford University Press, 2000). Pg, 50.

202 Ibid. p. 50.

203 Ibid. p. 53.
} 
mother's absence is particularly pronounced, and it this absence that lays the foundation for an incest scenario that leads the daughter to learn the skills of femininity. ${ }^{204}$

We see Laney in She's All That take a nurturing role over her brother Simon at the very beginning of the film, preparing him for school. She also watches over him when he is a target for bullies. She has taken the place of her dead mother in caring for the child while the father works, and as such shuns the romantic advances of Zack. The film disavows an incest scenario by allowing Laney to concentrate most of her attentions on the son, however it must be concluded that if Laney is acting mother she must also be acting as wife, fearing the 'break-up' that will ensue if she pursues a romantic relationship with another.

This scenario is convenient, as Karlyn has noted, in that it shows the girl has had a lack of 'feminine influence' - has not learned to copy and rote learn female behaviours. Laney is now shown to be so busy in her mothering role and repressing grief over the death through her painting that she will never be the object of cultural exchange unless there is intervention. Laney is left confused and broken, manifesting itself in an ambivalent appearance that does not comply with gender law. She is the manifestation of a scar caused by a broken home - a symptom of disease that threatens to replicate if there is not a return to traditional family values. Kat in 10 Things I Hate About You is angered at her mother leaving and takes a protective role over her sister Bianca, who she tries to keep from dating Joey by not getting involved in romantic relationships herself. ${ }^{205}$ While Laney's father is keen to see his daughter paired with Zack, Kat's father is

\footnotetext{
${ }^{204}$ Karlyn, Kathleen Rowe. 'Too Close for Comfort: American Beauty and the Incest Motif.' Cinema Journal. (44. No 1. 2004), pg 84.

${ }^{205}$ Ariane Balizet discusses the fact that Kat's nonconformity, her 'shrewishness', is shown to have resulted from a bad sexual experience and an effort to protect her sister in 'Teen Scenes: Recognizing Shakespeare in Teen Film.' Almost Shakespeare: Reinventing His Works for Cinema and Television. Eds. James R Keller and Leslie Stratyner. (North Carolina: McFarland and Company, 2004). Pg 130.
} 
sexually possessive, forcing his daughters to strap on fake bellies when they even think about dating. ${ }^{206}$

Sam in A Cinderella Story has been brought up by a single father who has raised her as he would a boy child. Gender ambiguity, the result of a lack of female influence, renders her invisible to Austin, as does her wicked stepmother's desire to keep her in servitude following the death of the father. The reign of the single father has given way to a far more terrifying form of power - that of the single stepmother. Patricia Watson in Ancient Stepmothers: Myth, Misogyny and Reality studies stepmothers in Graeco-Roman antiquity in order to analyse the continuing portrayal of the stepmother as an illustration of misogynistic prejudice. She notes that despite the high divorce rate and the fact that there are more stepfamilies than ever, the stereotype of the wicked stepmother still persists. ${ }^{207}$ The image of the stepmother was an encapsulation of negative traits assigned to females in general - self centredness, a lack of self control, prone to jealousy, cunning and treachery. ${ }^{208}$ Watson discusses the poisoning stepmother stock character in Roman antiquity, and the powers of the stepmother/witch to invert nature or the true female order. ${ }^{209}$

Bouvier and Moreau have looked at the Phineus myth as reflective of the disruption caused to the family when the nuclear family is destroyed by the introduction of a second wife. ${ }^{210}$ Fiona (Jennifer Coolidge) as stepmother is updated for the new millennium as a postfeminist narcissist, far too concerned with spending money on clothes, makeup and botox to nurture her biological daughters or Sam. She, metaphorically, poisons Sam’s nuclear family, by taking the position of mother and then failing to live up to society's expectation of that self-abnegating and nurturing figure. Donna Smith in Stepmothering writes that

\footnotetext{
${ }^{206}$ Karlyn, Kathleen Rowe. 'Too Close for Comfort: American Beauty and the Incest Motif.' Cinema Journal. (44. No 1. 2004), Pg. 85.

${ }^{207}$ Watson, Patricia A. Ancient Stepmothers: Myth, Misogyny and Reality. (Leiden: E.J Brill, 1995).

${ }^{208}$ Ibid. p. 22.

${ }^{209}$ Ibid. p. 3.

${ }^{210}$ Ibid. p. 47.
} 
stepmothers were used in the folktale to epitomise what came to be seen as an evil force - assertiveness in women, opposed to the heroine, who was synonymous with feminine virtues of service, passivity and beauty. ${ }^{211}$ Fiona has taken over Sam's father's business assets and used them in order to finance her consumer lifestyle - the passive Sam defenceless to stop her.

Here, I have wished to illustrate that the stepmother has long represented a force that threatens to poison and pollute the nuclear family structure and the role of the idealised mother. Of course, the manner in which the stepmother figure has been updated in this text is significant in that she feeds into conflicting worries regarding postfeminism and consumerism. While Sam harbours an inner ideal feminine core, like so many of the other teen makeover protagonists, she is imprisoned by her stepmother and her outward gender borderlessness. This borderlessless must be rectified so that she can break free of her stepmother and enter her rightful place in society. She deserves to be set on the path towards a happy, fulfilled and righteous life, but must be shown the way.

Occasionally the protagonist may live in a household with a single mother. Adrienne Rich has written that mothers are often either idealised as in myths of the nurturing, self-abnegating figure or disparaged as sadistic, neglectful and narcissistic. $^{212}$ The stepmother in A Cinderella Story is clearly a scapegoat for the latter, as these films tend to eclipse the mother figure altogether rather than deal with a figure who does not represent idealised notions of the role. The Princess Diaries has to be commended for portraying a mother figure who is a complex person in her own right with conflicting needs and desires, a portrayal which Rich has said is often absent in patriarchal representation. ${ }^{213}$

${ }^{211}$ Smith, Donna. Stepmothering. (Hertfordshire: Harvester Wheatsheaf, 1990). Pg 33.

${ }^{212}$ Kaplan, E Ann. 'The Case of the Missing Mother.' In Feminism and Film. Ed. E. Ann Kaplan. (New York: Oxford University Press, 2000). Pg 467.

${ }^{213}$ Ibid. p. 467. 
Helen Thermopolis (Caroline Goodall) is a freelance artist and rock climber who has abandoned the royal life in Genovia for what she perceives to be a more free existence in the USA. She desires a relationship with Mia's teacher but then becomes conflicted when her daughter fears ridicule over the new development, and she struggles to act as mediator between Mia and Queen Clarisse.

However, although we can read Helen's decision to stay in the USA as patriotic, choosing American values of liberty, we are also encouraged to read it narcissistically. Mia is clearly unhappy and not confident. At the beginning of the film she expresses dismay at what she sees in the mirror, and appears meek and mild in debating class, during which she runs from the room to vomit. Mia is actively involved in hobbies her mother likes, such as art and climbing, but these are the only activities she is shown to be able to do well. It would appear Helen has only schooled Mia in what is important to Helen, and has not trained her in anything that would allow her to benefit socially. It is Queen Clarisse, who teaches Mia the rules of an upper class femininity who truly restores her confidence. While rock climbing for women has been read as a positive transcendence over the immanence of the female gender, ${ }^{214}$ here it is seen as a means to cowardly escape on-ground duties - duties that require dedication to the presentation of performed femininity. Rock climbing is only allowed by the film when it takes place in an enclosed setting with clear limitations. Similarly, Mia's ascendance is only favoured when she does so within patriarchal norms. When Mia gets nervous and displays cowardice about accepting the position as Princess of Genovia, she packs her bags in preparation to travel to where she can climb real rocks outdoors - a decision which is revealed in the narrative to be the wrong one. Rock climbing for women outdoors, where there is no boxed in confinement, here then is equated with an antisocial shirking of one's responsibilities, and we begin to read the rock climbing mother negatively in accordance with the resignification of the activity. Did she shirk her duties also in order to rock climb? Aspects of character that might give way to an individualised empowerment are

\footnotetext{
${ }^{214}$ Dianne Chisholm uses women's climbing to explore the integration of feminism and phenomenology in 'Climbing Like a Girl”: An Exemplary Adventure in Feminist Phenomenology.' Hypatia (Vol 23, No 1, 2008).
} 
squashed in order to conform to an alternative misleading guise of empowerment that lies in the objectification of the female. This makeover is often granted to characters who display passive, docile or nurturing qualities - qualities that prefigure the idealised nurturing mother of the nuclear family that is perceived as being so under threat.

These films buy into the hysteria surrounding the breakdown of the American nuclear family by perpetuating the idea that single parent headed families are unviable. Children here do not learn the values needed to participate in society, and here the values to be learned are those associated with traditional white femininity. The girls in these texts are shown to be gender-confused, perhaps abject and monstrous beings, who are too strongly associated with the mind - an association ideally reserved for white male masculinity. There is an underlying threat that the thinking woman will value her own mind too greatly, and neglect to aim to invite male desire through her body, causing disintegration in the family structure. These adolescents are usually unaware of the threat they pose, thus constituting their tragic state, and often harbour an inner docility and passivity that pre-figures an idealised nurturant mother, which they could become in future after they learn to behave in the proper manner fitting for a woman. These figures are set up to be 'cured' through the pleasures of objectification so they do not remain in their cross-gendered abject state, or worse grow to become angry nonconformist feminists or consumer conscious postfeminists, who as we have seen, have been blamed for family breakdown. 


\section{Chapter Three: Deviant Teens: The Threat of Masquerade to Social Order}

In order for the heroine of the teen makeover film to be recognised as a somehow more 'natural' embodiment of future womanhood, she must be first compared and contrasted to other 'unnatural,' or deviant, female adolescent characters. These adolescents may vie for the attentions of the male love interest, as is the case in She's All That, A Cinderella Story, and Mean Girls, or they may simply resent the social elevation of the protagonist and seek to stand in her way (The Princess Diaries). As I have discussed earlier, these characters represent what the films perceive to be the pitfalls of a certain type of postfeminism - chick postfeminism. The deviant female adolescents adopt a masquerade of femininity in order to conceal their bid for mastery of the social body, with the degree of success they achieve resulting in a flawed sex role power dynamic. However, like the makeover protagonist, these characters also signify more widely when situated within the context of cultural debate over the susceptible and at risk adolescent.

Through the villains of the teen makeover film, it is possible to read a commentary on postfeminism, one that indicates girls and women alone are responsible for a renewed policing of the female body that impacts on them in a negative sense, as opposed to a policing of femininity that would guarantee their happiness and contentment. The postfeminist rules of femininity here have been conceived by females to gain power over other females, blame being placed on these characters for wider societal problems facing adolescents. These texts present the antagonists in their initial state as teen idols in the school and then work to expose them as threats to the other characters, (male and female), all the while working towards what the films ultimately see as a more sustainable version of femininity for society as a whole. Two films discussed in this chapter are Mean Girls and Wild Child. As is suggested by the titles of these two films, the narratives concentrate more on the characters of the deviant females than an awkward, abject protagonist. The first has protagonist Cady (Lindsay Lohan) undergo a makeover in order to decode the mechanics of power of the villainous 
girl group. The second features a deviant character as the protagonist, Poppy Moore (Emma Roberts), who is sent to a boarding school and undergoes a 'makeunder' to reveal a striking resemblance to her deceased, idealised mother.

\section{The Presentation of the Female Antagonist: Fear of the Mean Girl}

Judith Butler's 'heterosexual matrix' is a term for a constructed system that stabilises gender order and oppositional categories of sex. The antagonistic females of the teen makeover film would seem to be superficially reassuring in terms of the heterosexual matrix due to their hyper-femininity. However, the deviant female characters do not have the inner nurturant core that the central adolescent possesses. Instead, they are sexually aggressive, controlling and manipulative - traits characteristic of the chick postfeminist ${ }^{215}$ and young girl power icon. The villainous characters of the teen makeover film typically come from families with money, are avid consumers, and solely preoccupied with appearance. Appearance for the deviant teens is a means to get ahead - a way to become 'empowered.' In a sense, their attitude corresponds with the way postfeminist discourse operates in contemporary culture. These girls do not have a 'moral self,' 216 with everything and everyone simply existing to be consumed and discarded. Their self image is paramount, with romance ceasing to be a priority, or in fact to matter at all. Any heterosexual couplings are perceived to be status markers rather than an indication of romantic feeling. For instance, Taylor (Jodi Lyn O’Keefe) only stays with Zack in She's All That until she finds somebody who she perceives will be more impressive to her friends. The villains of the teen makeover film tend to belong to a pack, or gang of three or four members, which emphasises their threat towards the makeover protagonist who must prevail against the group in order to demonstrate that she is of a more worthy version of femininity.

\footnotetext{
${ }^{215}$ McRobbie, Angela. The Aftermath of Feminism: Gender, Culture and Social Change. (London: SAGE Publications, 2009). Pg. 21.

${ }^{216}$ Jane Arthurs argues that the ideal modern consumer does not have a moral self in 'Sex and the City and Consumer Culture: Remediating Postfeminist Drama.' In Feminist Television Criticism: A Reader $2^{\text {nd }}$ Edition. Eds. Charlotte Brunsdon and Lynn Spiegel. (Berkshire: Open University Press, McGraw-Hill Education, 2007). Pg. 51.
} 
While the central character does also gain empowerment through the manipulation of appearance, this usually takes place under a personified patriarchal gaze and serves to make her more attractive to a love interest. Pre-makeover, the protagonist's true social value is hidden beneath a rough exterior. The deviant female in the text is this character's opposite; her immoral character hidden beneath a carefully manipulated, beautified, and 'plastic' exterior, designed to ensnare victims in order to use them for her own ends. The teen makeover film aims to draw a clear line between good girls and bad girls - with the bad girls being depicted as such for the off-script way in which they choose to utilise their status as objectified beings for the male eye. This initial division between female adolescents in the filmic space works to present to the viewer the two versions of femininity that will collide in the course of the narrative, with only one version allowed vindication.

Adolescents in the teen makeover film are marked as future citizens with the high school acting as a correctional space where behaviour and appearance may be modified in order to stabilise sex and gender hierarchical norms. These norms are portrayed as encouraging and vilifying the notion of 'true love' at a time when women are motivated to work and enjoy disposable income before starting a family, ${ }^{217}$ and where groups of women or girls in the media are manufactured and marketed as a kind of surrogate girl power family that girls can buy into. ${ }^{218}$ Sarah Projansky, in noting the prevalence of young girls on the cover of Time, quotes Lauren Berlant in saying that in circulating the image of young girl as future citizen, there involves a policing of morality around sex and other transgressive representations. ${ }^{219}$

\footnotetext{
${ }^{217}$ Harris, Anita. Future Girl: Young Women in the Twenty-First Century. (New York and London: Routledge 2004). Pg 23.

${ }^{218}$ Hopkins, Susan. Girl Heroes: The New Force in Popular Culture. (Annandale: Pluto Press, 2002). Pg 16.

${ }^{219}$ Projansky, Sarah. 'Mass Magazne Cover Girls: Some Reflections on Postfeminist Girls and Postfeminism's Daughters.' In Interrogating Postfeminism: Gender and the Politics of Popular Culture. Eds. Diane Negra and Yvonne Tasker. (Durham and London: Duke University Press, 2007). Pg. 49.
} 
As the depictions of young female sexuality in the media become more overt, with sex between core characters being the key theme in teen-targeted shows like The $O C$ and the recent hit Gossip Girl, and with young pop stars wearing less clothing and singing more suggestive lyrics, the future girl, the 'real girl,' comes to be seen as more vulnerable, innocent and endangered. In fact, Projansky notes, girls are in danger simply by existing. ${ }^{220}$ She points out that the active mean girl, (and the word active here is important given the commonly passive tendencies of the teen film protagonist), contributes to the trauma of other vulnerable girls. Projansky believes this girl is 'at risk' at least in part due to her own bad choices. ${ }^{221}$ However, the mean girl may be a prevalent image, but she is not always characterised as deviant unless she is blamed for the low self-esteem of other teenage girls or blamed for the sexualisation of this same group. In fact, she can serve as a role model for girls in girl power culture.

Diane Negra has noted that many films in the contemporary romantic comedy genre display a fear of female agency and desire. ${ }^{222}$ This can also be said to be true of the teen makeover film. The heroine is commonly engaged with the needs and concerns of others while displaying a romanticised emotional passivity in relation to her own desires. ${ }^{223}$ Resentment, anger and jealousy, emotions that every human being experiences, are transferred onto the mean girl, the character that the virtuous protagonist must defeat. ${ }^{224}$ While Negra appears to believe that a retreatism back into pre-feminist nuclear family roles is characteristic of postfeminism as a whole, I think the teen makeover film articulates two variants of postfeminism that duke it out in the text - that of chick postfeminism against the more retreatist mode that Negra describes. The teen makeover film often attempts to resurrect the nurturant pre-maternal figure, the virginal icon, commonly seen in Disney constructions of the feminine and reminiscent of pre-

${ }^{220}$ Ibid. p. 52.

${ }^{221}$ Ibid. p. 56.

${ }^{222}$ Negra, Diane. What a Girl Wants? Fantasizing the Reclamation of Self in Postfeminism. (London and New York: Routledge, 2009). Pg 140.

${ }^{223}$ Ibid. p. 140.

${ }^{224}$ Ibid. p. 140. 
feminist makeover femininities, against the girl power icon, the latter being very influential over modern day girls’ spending habits and how they present themselves.

\section{Reassuring Femininity? The Female Masquerade - Shades of the Femme Fatale}

In accordance with Sandra Lee Bartky’s theories on the disciplined and practiced female body, the antagonist in the teen makeover film would appear to have internalised the male gaze and thus be completely subjected under patriarchal authority. These bodies are highly gendered ones, schooled in makeup application, feminine movement and dieting. The key deviant characters in She's All That, Mean Girls, A Cinderella Story and Wild Child are all stiletto-clad, pink wearing, long blonde-haired 'Barbie doll' types. In fact, the core girl gang in Mean Girls is nicknamed 'The Plastics'- indicative of their faked malleable brand of popular femininity. The girl gang in Never Been Kissed all decide, without one another's knowledge, to come dressed as Barbie for the school prom. For all of the deviant characters in the above listed films, shopping is the key extracurricular activity. She's All That, Mean Girls and Never Been Kissed all feature scenes in which these girls are laden down with boutique-style shopping bags. These characters are able to afford such expeditions because all, without exception, are from wealthy families. In fact, it is worth noting here, that while the depiction of the teen makeover protagonist may shift slightly from text to text, the portrayal of the antagonist adolescents remains remarkably static and stereotypical. Even Wild Child, which has a deviant girl as its protagonist, does not sway from the character rules for this formulaic depiction. The only teen film studied here without the seemingly mandatory 'girl gang' is 10 Things I Hate About You. Bianca Stratford, protagonist Kat's younger sister, is close to becoming one of these characters. She is sought after by the males in the school and is an avid shopper; her shallowness becomes clear when she explains the difference between like and love in relation to Sketchers and Prada rather than in terms of human interaction. However, Bianca is also naïve and virginal, in stark contrast to most makeover antagonists, 
and these traits allow Kat to 'save' her before she goes down the wrong path while she is simultaneously saved herself.

Most of these films take a swipe at these characters' lack of intelligence, despite the fact that at the same time the narrative often seeks to de-intellectualise the protagonist. One of the blonde mean girls in the film of the same title tells Lindsay Lohan's Cady that she has 'psychic ESPN...a fifth sense,' while Shelby in $A$ Cinderella Story is forced to copy in algebra tests. Never Been Kissed refrains from attacks on intelligence until the girl gang members all show up at a dance wearing blonde wigs and don a blank gaze when Drew Barrymore’s Josie tells them she is dressed as a Shakespeare character. These films then persist in perpetuating a stereotype that links blondeness with stupidity. ${ }^{225}$ The key character in Wild Child, Poppy, even undergoes a hair colour change from blonde to brunette to reflect her new less vapid, 'more English,' personality. The power of these characters lies in their expertise in manipulating appearance. As Zack says of ex-girlfriend Taylor in She's All That after she has broken up with him for a TV star, 'once you strip away the attitude and makeup, underneath is a C-minus GPA wearing a wonder bra.' So, if these deviant bodies are subjected and practiced in performing a femininity that seeks to objectify them, and are certainly not threatening in terms of an association with the mind in the way that the protagonist is, why then, are they cast as the villains of the piece? The answer may lie in theories of the feminine masquerade.

The idea of a female masquerade was first explored in relation to film by Mary Ann Doane, although the theory was first conceptualised by Joan Riviere. Doane bases her hypothesis on Freud's work 'Some Psychological Consequences of the Anatomical Distinction Between the Sexes,' which looked at how boys and girls react upon first seeing the genitals of the opposite sex. According to Freud, the girl, upon first seeing the penis, knows that she is without it and wants to have it.

\footnotetext{
${ }^{225}$ Marina Warner points to the associations between blondeness and the infantile, as well as long hair and the dumb animal, in From the Beast to the Blonde: On Fairy Tales and Their Tellers. (London: Chatto \& Windus, 1994). Pg 360-368.
} 
The boy, upon seeing female genitals, disavows what he has seen or looks about for ways to make what he has seen conform to his expectations. ${ }^{226}$ Doane mentions the observation made by both Freud and Cixous that the woman seems to be more bisexual than the man - female transvestism is an occasion for desire. ${ }^{227}$ Doane understands that women would want to be men, noting the lack associated with the feminine position, but questions why woman would want to produce herself as excessively feminine - which is how the antagonistic characters in the films studied here are portrayed. Doane quotes Montrelay in saying that the woman can use 'her own body as a disguise' for particular gains, something a man does not have to do. ${ }^{228}$ Masquerade, the mask of womanliness, is something that can be worn or removed. Interestingly, Doane points out that the masquerade is associated with a particular recurrent female character in cinema the femme fatale:

'The femme fatale...is necessarily regarded by men as evil incarnate. It is this evil which scandalises whenever woman plays out her sex in order to evade the word of the law. Each time she subverts a law or a word which relies on a predominantly masculine structure of the look. ${ }^{229}$

Doane explains that the most striking characteristic of the femme fatale is that she is never the figure she appears to be. As a figure which emerged in the $19^{\text {th }}$

Century, the femme fatale overrepresented the body in a compensatory gesture at a time when the male working body became displaced by industrialisation. It is this fact which Doane uses to explain why the femme fatale is a recurrent figure in the cinema, a technology of representation, noting that she appears as the vamp of Scandinavian and American silent cinema, the diva of the Italian film and the

\footnotetext{
${ }^{226}$ Doane, Mary Ann. 'Film and the Masquerade: Theorising the Female Spectator.' In Feminism and Film. Ed. E. Ann Kaplan. (Oxford and New York: Oxford University Press, 2000). Pg 425.

${ }^{227}$ Ibid. p. 426.

${ }^{228}$ Ibid. p. 427.

${ }^{229}$ Montrelay quoted by Mary Ann Doane in 'Film and the Masquerade: Theorising the Female Spectator.' In Feminism and Film. Ed. E. Ann Kaplan. (Oxford and New York: Oxford University Press, 2000). Pg 427.
} 
femme fatale of 1940s film noir. ${ }^{230}$ Janey Place adds that it is the combination of sensuality with activity and ambition which defines this archetype, her strength standing in contrast to a passive and impotent noir hero. ${ }^{231}$ The villains of the teen makeover film do have much in common with the femme fatale in their bid for power through masquerade and sexuality. Yvonne Tasker in Working Girls has noted that the femme fatale draws on a tradition of defining woman not only by sexuality but by the power this definition can generate. She is a transgressive figure who misleads the hero, her appeal for feminists lying in her possible refusal of patriarchal values. ${ }^{232}$ Tasker points out that this deviant figure is generally constructed in opposition to a 'good woman' with nurturing qualities. ${ }^{233}$ The teen makeover villain, unless the film is centered on this character, is commonly constructed as bad girl to the good girl - here, a nurturing and chaste adolescent who prefigures the good woman. It is sexual appeal and the powers of seduction that cement their place at the top of the social order within the school, keeping male characters at their beck-and-call. In privileging material objects, self visibility and social hierarchy over romance, the bad girls in the teen makeover film could be seen to be undermining the patriarchal values that hold the nuclear family to be the core of a stable society. The femme fatale however, (and the common perception of this figure stems from 1940s film noir), is commonly portrayed as 'exotic,' a threat to the wholesome American woman. Certainly, she is never presented literally or symbolically as on the cusp of womanhood.

Teen makeover film antagonists are not associated with that which is supposedly un-American - quite the contrary. Their bid for power through a feminine disguise, masquerade, is not achieved by operating outside of cultural convention at the level of appearances. This particular type of masquerade is reassuring not only because gender is seen to follow on from sex seamlessly, but because the

\footnotetext{
${ }^{230}$ Doane, Mary Ann. Femmes Fatales, Film Theory, Psychoanalysis. (New York and Oxon: Routledge, 1991). Pg 2.

${ }^{231}$ Place, Janey. 'Women in Film Noir.' Women in Film Noir. Ed: E. Ann Kaplan. (London: British Film Institute, 1998). Pg 63.

${ }^{232}$ Tasker, Yvonne. Working Girls: Gender and Sexuality in Popular Culture. (London: Routledge, 1988). Pg 120.

${ }^{233}$ Ibid. p. 121.
} 
masquerade resembles American consumer culture iconography. As I have mentioned, there is a link between these characters and American cultural icon Barbie, (with the pastel clothes, blonde hair, convertible and associations with the unnatural, that which is plastic, shallow and fake). The blonde hair of the protagonists is integral to the specific masquerade appropriated by the antagonistic characters. Marina Warner notes that while blonde hair has traditionally been linked to that which is pure, clean and virginal, the 1930s and 1940s influence of Hollywood overlaid the traditional associations with a 'vampy' sexual knowingness. ${ }^{234}$ By having blonde hair, the antagonists are marked as both reassuring and potentially threatening. The further association of the deviant characters with the artificial and impossible manipulated model of female perfection, the Barbie doll, indicates that they are knowledgeable of the connotations associated with blondeness and have appropriated it through artificial means in order to further their own ends. This doll-like image is one which is common to teen pop stars, (Britney Spears, Jessica Simpson, Christina Aguilera), and socialite/celebrities like Paris Hilton and Nicole Richie. In fact, many of these stars have Barbie-like dolls made in their likeness that girls can buy. Susan Hopkins points out that female pop culture icons, here concentrating on supermodels, need to demonstrate a certain plasticity in that they must be able to convey several different images at once. ${ }^{235}$ She notes that magazines like Cosmo celebrate Barbie as the most famous fashion model and icon of hyperfemininity because she 'promises aesthetic mastery in a world of beautiful things. ${ }^{236}$ Similarly, Jessica K Taft writes that Barbie functions as a girl power icon, noting that marketers use girl power discourse to circulate the image of girl as consumer, thus confining girls’ social power to consumer power. ${ }^{237}$

\footnotetext{
${ }^{234}$ Warner, Marina. From the Beast to the Blonde: On Fairy Tales and Their Tellers. (London: Chatto \& Windus, 1994). Pg 362.

${ }^{235}$ Hopkins, Susan. Girl Heroes: The New Force in Popular Culture. (Annandale: Pluto Press, 2002). Pg 106.

${ }^{236}$ Ibid. p. 107.

${ }^{237}$ Taft, Jessica K. 'Girl Power Politics: Pop Culture Barriers and Organizational Resistance.' All About the Girl: Culture, Power and Identity. Ed. Anita Harris. (New York and Oxon: Routledge, 2004). Pg 74.
} 
The teenagers in the films are both consumers of this culture and proponents of it. The antagonists then are presented as being reassuringly all-American girls to the social body, particularly the males, within the films, but they are also exposed to the viewer as being a particularly and perhaps uniquely American problem, part of a new girl power consumer culture storming the country. The father's solution to save his 'wild child' in the film of the same name is, after all, to send her off to England in the hope that traditional 'English culture,' here offered as a boarding school, a strict headmistress and highly classed system, will straighten out the corruption to her character that being an American teen particularly susceptible to the messages of postfeminism has caused.

\section{The Postfeminist Masquerade}

The overtly feminine masquerade is not in today's times presented as something that the occasional female may put on in order to get ahead; in a chick postfeminist society, it is expected. This masquerade, a postfeminist one, may be distinguished by a focus on the performance of youthful and adolescent-like, but still sexual, femininity. The teen makeover film does not reject a masquerade of femininity - its main plot purpose is after all to physically make over an 'ugly duckling' so that she may invite objectification and desire. This masquerade however has to be reminiscent of a 'traditional' ideal of femininity. It must be carefully manufactured by a superior body and apportioned to one who has no agenda for domination, its prime purpose to make this idealised type of female romantically desirable. These films are critical of what a quintessentially postfeminist masquerade may mean however for sex and gender roles, and, as a result, the future family unit, if girls and women come under the spell of 'girly' raunch culture, which Ariel Levy describes as an era where women make sex objects out of other women and themselves, having been told they no longer need to worry about misogyny and objectification. ${ }^{238}$ Levy notes that in a world where pole dancing and Brazilian waxes are labelled empowering, all empowered

${ }^{238}$ Levy, Ariel. Female Chauvinist Pigs: Women and the Rise of Raunch Culture. (New York: Free Press, 2005). Pg 2. 
women need to be overtly sexual as 'hotness' becomes cultural currency. ${ }^{239}$ The girl as future citizen in the teen makeover film has her worth closely tied to her sexual and consumer behaviour. The antagonist, in her appropriation of a postfeminist masquerade, cares only for pleasure and status, and has no concern for non-material values. Both friendship and love are power play games in films such as She's All That, A Cinderella Story, and Mean Girls.

\section{In The Aftermath of Feminism: Gender, Culture and Social Change, Angela}

McRobbie describes the postfeminist masquerade as functioning with microscopic attention to detail. ${ }^{240}$ McRobbie sees this artificial femininity as an attempt to stabilise gender relations as women inhabit positions of authority, ${ }^{241}$ believing the postfeminist woman fears seriousness and wishes to 'disavow the castrating figures of the lesbian and feminist with whom she might conceivably be linked.' McRobbie believes the postfeminist masquerade is a nervous gesture on the part of young women, who are 'almost inappropriately eager to please.' ${ }^{242}$ She says postfeminist women who utilise the masquerade are nervous because they are unused to power - they are inexperienced. ${ }^{243}$ Unlike Doane, McRobbie does not draw a link between femme fatale-like images and the masquerade - in fact she uses popular 'chick lit' character Bridget Jones in order to illustrate the embodiment of what she means by the term. As she argues;

'In practice it can be read as a nervous gesture on the part of young women, (think of Bridget Jones's short skirt and flirty presence in the workplace and her 'oh silly me' self reprimands), who have become aware that their coming forward and competing on the labour market with men as their equals has certain repercussions.' 244

${ }^{239}$ Ibid. p. 31.

${ }^{240}$ McRobbie, Angela. The Aftermath of Feminism: Gender, Culture and Social Change. (London: SAGE Publications Ltd, 2009). Pg 66.

${ }^{241}$ Ibid. p. 68.

${ }^{242}$ Ibid. p. 67.

${ }^{243}$ Ibid. p. 66.

${ }^{244}$ Ibid. p. 66. 
I would argue that Bridget Jones perhaps resonated with women because she is a failure when it comes to appropriating a postfeminist masquerade. I don't mean this in that the character is somehow unmasked to reveal a woman who does not comply with the heterosexual matrix, for this is not the case. The quintessential representation of the postfeminist woman is highly controlled and judgemental of her own femininity, which Bridget Jones is, but is successful at this monitoring, which Bridget Jones is not. The masquerade is supposed to look effortless, for instance the trend for 'natural looking' make-up, and the goal towards reaching a cool and casual attitude towards food and exercise. ${ }^{245}$ While many girls and women in their everyday lives may feel anxiety in trying to live up to stringent standards of the feminine, figures in the media, whether they be stars or characters on screen, rarely articulate this. Bridget Jones is an unlikely postfeminist icon in this respect. As Diane Negra has noted, a hallmark of postfeminism is composure. ${ }^{246}$ What is being sold to younger and younger females now is empowerment through being hyper-feminine, through masquerade, not merely that one must be hyper-feminine as a result of empowerment. It is empowerment through the embrace of femininity that is preached by the girl power icon and it is this idea that is embodied by the teen makeover film antagonists.

However worrisome the postfeminist mantra can sometimes be, (the decision to undergo plastic surgery to fit unrealistic body ideals is often promoted as being an empowering one for women), ${ }^{247}$ it is nevertheless true that one's social standing is likely to be elevated by adhering to these rules of femininity. The teen makeover film antagonists achieve success in their bid for power because they have the traits that popular postfeminism deems necessary for success. The teen makeover film exhibits a fear that this postfeminist mantra, to shop one’s way to visibility,

\footnotetext{
${ }^{245}$ Susan Bordo discusses the fantasy of a casual relationship with food in Unbearable Weight: Feminism, Western Culture and the Body. (Berkeley and Los Angeles: University of California Press, 1993). Pg 100. ${ }^{246}$ Negra, Diane. What a Girl Wants? Fantasizing the Reclamation of Self in Postfeminism. (London and New York: Routledge, 2009). Pg 139.

${ }^{247}$ Morgan, Kathryn Pauly. 'Women and the Knife: Cosmetic Surgery and the Colonization of Women's Bodies. In The Politics of Women's Bodies: Sexuality, Appearance and Behaviour. Ed. Rose Weitz. (Oxford and New York: Oxford University Press, 2003). Pg 165.
} 
adoration and status, could be taken so far as to negate the need for males romantically, as females fall further and further into self devotion and promotion.

The figure of the image-obsessed social climber in the teen makeover film is a threatening one exactly because she does fulfill the heterosexual matrix at a superficial level, but on the inside she is not vulnerable, passive or demure. Regina from Mean Girls dresses in pink, wears feminine clothing, such as skirts and dresses, and engages in appropriately feminine activities, like gossip and shopping. She looks and acts like a girl and appears to desire Aaron. However, she does not display vulnerability, seemingly secure at the top of the social food chain, and she is aggressive in going after what she wants at the expense of others. Other girls cannot wear the same clothes as her on specific days so that she will stand out from the crowd, and she appears to only want Aaron because Cady does, going to any lengths to win him back. She feigns sweetness when complimenting others, but then makes fun of them behind their backs. In opposition to the protagonist, who has a feminine core but at surface levels cannot invite desire, the antagonist can get males to do her bidding exactly because she conforms to gendered appearance norms, fetishising her own body in order to lure people in. The result of girl gang/girl power culture for the teen makeover film is a matriarchal school society where teenage boys are in masochistic positions when in relationships with chick postfeminist teenage girls. The teen makeover film does not call for a rejection of female masquerade, rather it calls for patriarchal culture to recognise the mask of the feminine and to reclaim it for the good of society.

\section{Masochistic Relationships and the System of Reliance}

Of utmost importance to the characterisation of the consumer-driven teen as villain in the teen makeover film is her relationship to male teenagers in the text, and how male characters are led to behave following their involvement with the antagonist girls. The key goal of the contemporary teen makeover film is to achieve a balance of gender roles within a binary system. True love, social health 
and happiness result from this stabilised sex and gender order. Failed pairings, those that do not achieve this balance of gender roles within the binary system, usually are between the leader of the school's girl gang and the key male character, (he who ends up with the protagonist). It would be most accurate to describe these relationships as having a masochistic bent, however there are even elements to these masochistic relationships where the true agenda of the female in question is hidden beneath a carefully cultivated masquerade of attitude as well as appearance. Deviant females in the teen makeover film, in their position of power and influence within the space of the school, are held up to be proponents of fashionable gendered ways of being and behaving that contribute to the social derailment of others. Within the text, the artifice of the female masquerade coupled with a bid for power and control is shown to lead to the emasculation of male characters, who are all too easily manipulated into a dependent position by these girls, as I will explore below.

In most relationships involving the anatagonistic female character in the teen makeover film, it is evident that that it is they who are in control rather than their male counterparts. Stock scenes in these films that serve to demonstrate that these characters reign over the student body may include the introduction of their table in the student cafeteria, which is at the centre of the activity and is reserved only for members of the girl gang, (as seen in Mean Girls and Never Been Kissed). There are usually also scenes which show the clique storming down school hallways, other students scurrying out of their path (particularly evident in $A$ Cinderella Story and Mean Girls, although these characters are shown to stride purposefully, quickly and confidently in She's All That and Never Been Kissed also, all the while wearing high heels of course).

It is worth noting that this masterful use of space stands in stark contrast to the teen protagonist, who repeatedly stumbles, falls and collides with objects or people in her path. This mastery of space by these deviant females indicates their control, or tyranny, of the area and of the people around them. While they appear 
hyper-feminine, their mastery of space is decidedly masculine and acts as one of the first indicators of the threatening nature of the girl gang. The makeover protagonist cures her flawed navigation of space with the help of a male guide, or map maker, learning to navigate her way through space with a newfound feminine grace, respectful of objects in her path. She is guided through space because she has agreed to accept a set of conditions imposed on her bodily existence. The antagonists have no such guide, and have accepted a different set of conditions. Their use of space relies on a commanding presence which inspires fear. They demand subservience of the bodies in their space, showing disrespect for these perceived lesser beings.

In She's All That, it is shown that Zack's reputation is staked on his relationship with Taylor, who his friend points out, 'every girl wants to be and every guy wants to nail.' When she breaks up with him for Brock Hudson (Matthew Lillard) from television's The Real World because she is impressed by the latter's celebrity status, Zack takes the bet to make Laney Prom Queen in order to save face and prove that he has power in the school... or more specifically, the power to raise the social status of girls within the school. Zack has to prove that he does not need Taylor in order to be admired.

In Mean Girls, Regina George (Rachel McAdams) keeps on/off boyfriend Aaron (Jonathan Bennett), who protagonist Cady is also in love with, at her beck-andcall. She is able to send him away and then lure him back using 'feminine wiles.' Regina is clearly in control, able to behave however she likes because she is the 'Queen Bee.' Aaron reacts strongly when Cady calls him 'Regina's property,' in a scene meant to show us that Cady has become a copy of Regina... and yet this is precisely what Aaron is. Lana (Mandy Moore) in The Princess Diaries uses Josh (Erik von Detten) as a status marker and refers to him possessively as 'my man,' although in this case, the male is equally as untrustworthy as the female, with Mia eventually rejecting Josh in favour of the more gentlemanly Michael (Robert Schwartzman). Poppy in Wild Child initially attempts to use Freddy (Alex 
Pettyfer) in order to get kicked out of school despite the fact that he genuinely begins to like her, and she learns the error of her ways as she ceases to act like a mean girl and instead embodies the image of her own deceased idealised mother. In A Cinderella Story, Sam's love interest Austin initially stays with controlling and manipulative Shelby (Julie Gonzalo) due to her wealth, status and attractiveness, before learning that made-over Sam is a more 'genuine' model of femininity - i.e. passive, nurturing and obedient.

In 'Masochism and the Perverse Pleasures of Cinema,' Gaylyn Studlar aims to offer up an alternative model to current theories of film spectatorship, for instance to that put forward by Laura Mulvey, which emphasises voyeurism, sadism, and objectification of the female under a masculine controlling gaze. ${ }^{248}$ To do this, Studlar uses Deleuze to differentiate between sadism and masochism, pointing out that, in the world of Sade, the 'father is exalted beyond all laws', while the world of Masoch is centered on love for the punishing woman. The female in the masochistic scenario inflicts cruelty in love in order to fulfill her role in a mutually agreed upon arrangement. ${ }^{249}$ Masoch's work subverts patriarchal power relations, with the male as slave willing to transfer power to the female. ${ }^{250} \mathrm{By}$ contrast, Sade may choose a woman as heroine only to destroy her. In a sadistic fantasy, the subject must take the position of a controlling parent, but he has power over an unwilling victim. ${ }^{251}$ In a masochistic text, the female is not a discarded object, but an idealised, powerful figure both dangerous and comforting. Using a Von Sternberg film, Morocco, as an example, Studlar explains that the film's masochistic aesthetic presents the image of the female as both object of the look, but also as bearer of a controlling gaze; 'In response to the male gaze, Marlene Dietrich looks back or initiates the look. This simple fact contains the

\footnotetext{
${ }^{248}$ Mulvey, Laura. 'Visual Pleasure and Narrative Cinema.' In Feminism and Film. Ed. E Ann Kaplan. (Oxford and New York: Oxford University Press, 2000).

${ }^{249}$.Studlar, Gaylyn. 'Masochism and the Perverse Pleasures of the Cinema.' In Feminism and Film. Ed. E. Ann Kaplan. (Oxford and New York: Oxford University Press, 2000). Pg 204.

${ }^{250}$ Ibid. p. 204.

${ }^{251}$ Ibid. p. 208.
} 
potential for questioning her objectification., ${ }^{252}$ A sadist must consume or destroy the object in order to experience the pleasure of orgasm, but for the masochist this is not the goal. A masochistic relationship guarantees distance. ${ }^{253}$ The male escapes castration anxiety by fetishising the woman rather than demystifying her through voyeurism. ${ }^{254}$

While this description cannot be mapped in an entirely unproblematic manner onto the presented as undesirable relationships in the teen makeover film, Studlar's explanation of the masochistic relationship nevertheless provides a useful template for analysis. Despite the fact that the deviant female in the films is punishing, the male remains bound to her - awed by her. The male is willing to transfer power to her and it is she who controls the dynamic of the relationship. For instance, although Taylor in She's All That is cruel, petty and relatively dismissive of Zack, he is caught up in Taylor's 'aura,' what she represents as an ideal of femininity to the social body within the school. Zack needs Taylor in order to keep his own status intact and therefore accepts an arrangement that places him in a dependent position. In a sense Zack’s persona, what others perceive him to be, is sustained by Taylor. It is she who keeps the idealised image of Zack alive. Without her, he will cease to be. It is Taylor's image that sustains Zack's image and it is hers that is initially more powerful. This is equally true of Regina and Aaron in Mean Girls or Shelby and Austin in A Cinderella Story. The deviant girl of the teen makeover film is objectified and fetishised, yet at the same time is bearer of a controlling gaze. There is a certain pleasure/pain repetition in some of these relationships, for instance Regina repeatedly rejects and then courts Aaron. Unlike in the masochistic relationship however, the female in the films studied here does not inflict her cruelty out of love, for, it is depicted, love is an often alien emotion to the status-obsessed girl and, by extension, the girl power icon or postfeminist girl gang.

\footnotetext{
${ }^{252}$ Ibid. p. 212.

${ }^{253}$ Ibid. p. 215.

${ }^{254}$ Ibid. p. 213.
} 
However, the male in the films, because he needs the female for social survival, may convince himself that this element is in fact in place. Both Zack and Aaron are shocked and hurt when their love interests pull away or reject them, and yet, given what we are shown of these deviant characters, this behaviour is completely typical. The masochistic relationship is itself a farce, or masquerade for the real motives behind the union. Because the deviant female does not have these internal, nurturing and kind feminine characteristics that are so cherished in the makeover protagonist, she really is not the figure that her partner in the scenario wants her to be. These relationships are not built out of love but by a desire to control a male figure and a social space. The male's place in the subsequent 'romantic' partnership is somewhat ambiguous, or unintelligible within accepted codes of heterosexual romance, because he becomes an object with no active capacities. As a result, these partnerships which are carefully orchestrated by the deviant female are shown to contribute to a redundancy of active masculinity impotence. $^{255}$

The aim of the teen makeover film is to correct the power dynamic where the female exerts too much authority and put the male back into his rightful position of patriarchal dominance. In the films where the makeover is initiated from a bet situation, (particularly pronounced in She's All That), the male is encouraged to turn a voyeuristic eye on the female object of the bet, achieving a symbolic sexual satisfaction in his branding of her and a reaffirmation of his active role. In accordance with sadist discourse, the male here exerts power over an unwilling victim. I am reluctant to say that the female makeover protagonist is destroyed or loses her subjectivity due to her submissive position - instead she undergoes a more complex redirection of values and desires related to the timeframe in which the films are produced that cannot be entirely accounted for through a psychoanalytic reading, a matter I will discuss in depth in Chapter Four. By the

\footnotetext{
${ }^{255}$ Jessica Valenti points out that the sexual activity of girls leading to a feminizing of masculinity is an argument used by those in the virginity movement, referring to author Laura Sessions Step in The Purity Myth: How America's Obsession with Virginity Is Hurting Young Women. (California: Seal Press, 2009). Pg 53.
} 
conclusion of the film, the male is shown to have learned the error of his cruel ways and to have learned that the female is human rather than mere object to be gambled, he is responsible for her newfound brighter destiny, and the subsequent relationship is supposedly one of harmony rather than pleasure and pain. Her objectification through the makeover, despite the cruelty with which it may have come about, is presented as necessary for her wellbeing and happiness. This central couple achieves harmony and wholeness, in opposition to relationships characterised by their distance. We are to assume this central relationship will remain stable into the future. The deviant girl fulfilling the position of power in the masochistic scenario is rejected as shallow, vapid and ultimately unworthy of romance.

\section{Faked Body Neurosis: Artificial Female Body Shame in the Teen Makeover}

\section{Film}

Despite the fact that, upon analysis, the construction of the makeover antagonists reflects the image construction of girl power icons in the entertainment media, there is little in the way of analysis of their behaviour in the films. While there is an indication that growing up in a single parent family and an over-investment in intellectual matters is responsible for the initial waywardness of the protagonist, we are rarely privy to being able to view the families of the antagonists. Two notable exceptions are Wild Child and Mean Girls. In the first, Poppy contributes to her father's powerlessness due to her 'wild' behaviour, leading to, in a particularly disturbing incidence of the incest scenario, a makeover that reveals her striking resemblance in appearance and behaviour to her late mother. She is evaluated through the prolonged (and misty-eyed) male gaze of her father at the end, her femininity found to be of worth once again. Is it possible that Poppy has turned to girl power postfeminist culture, embracing artificiality over the natural and real pain of her situation?

Regina George's mother (Amy Poehler) in Mean Girls, in a dig at the postfeminist obsession with youth, tells Regina's friends that she is 'not a regular mum, but a 
cool mum,' and has spent her husband's money on breast implants, (leading to a comic scene where the family dog chews on her breasts, but she is unaware of it because she has no nerve sensation in the area). She displays no concern when Regina has sex in the house while she is there and actively encourages Regina to sexualise her body, taking photographs of her daughter provocatively posing in a Halloween Playboy costume while her husband shakes his head in dismay. Again, the patriarch is powerless to stop the scourge of shallow, vapid femininity. Also in Mean Girls, in two brief shots, Regina's young sister is seen copying provocative dance moves from a pop star on television. Are we to infer that Regina also has copied her deviant behaviour from media icons? Or are we to blame the postfeminist mother who does not police what her daughters are subjected to on television in the same way that she does not police what they do in her house?

Even with these two examples, the films do not appear to offer much in the way of reasoning for what they frame as a postfeminist masquerade out of control. All of the deviant female characters are highly competitive and antagonistic - there is no place for female friendship, unlike the postfeminist girl gang in music and television where friendship is integral to the success of the construction. The deviant teen female groups in the teen makeover film are reminiscent of girl power formulae, but there is an exception in that members are not protective of one another. Instead the girls are positioned within the group in a hierarchy based on competition and deceit. The gang is more like an unsavoury government than a group of friends, with films like Mean Girls suggesting members would be happier if they separated and found better influences on their characters.

Feminine masquerade is about heightening one's social worth - the goal being to commoditise one's body in a manner that will inspire awe and servitude from those who don't measure up. The makeover film villains are shown to constantly obsess over their appearance, with Mean Girls, Never Been Kissed, and A Cinderella Story all featuring scenes where the girls, (to other members of their group), evaluate the fat content in food. Shelby in A Cinderella Story asks Sam 
smugly, while ordering in the diner, for something which has no sugar, no carbs and is fat free. Her line is meant to send Sam scurrying for something in order to accommodate her. The line is delivered in order to let Sam know that Shelby is really beneath eating in such a low-brow establishment; it is not born out of a real fear of gaining weight.

In Mean Girls, evaluating the body is a ritual. One scene shows 'The Plastics' standing in front of a mirror making claims such as 'I have man shoulders' and 'my pores are huge' before turning to Cady, expecting her to make a contribution. Regina's claims that she needs to lose three pounds are followed with an expectant glare, at which time the other girls in the group are supposed to remind her of her idealised slenderness. Female body shame in these instances is part of the mind games the deviant characters play in order to get one up on each other and in order to reinforce their own superiority. In having little in the way of reasoning for the behaviour of the deviant teens, and in portraying the link between the performance of femininity and the policing of the female body as merely a construct of the deviant female mind, a further tool in the arsenal in order to get ahead, the teen makeover film orchestrates a blame shift in regard to the current restrictions placed on the female body.

While it is true that girls do police themselves and each other to ensure conformity with standards of attractiveness, ${ }^{256}$ to portray this as nothing but a female power play game divorced from its patriarchal origins is to negate the real stress and anxiety that girls and women face everyday trying to live up to near impossible physical standards. This stress and anxiety is virtually absent in the teen makeover film, with scenes like those described above sending a message that body dissatisfaction is merely part of the postfeminist masquerade.

\footnotetext{
${ }^{256}$ Jessica Valenti cites findings from a 2007 American Psychological Association report that found that girls' relationships with parents, educators and peers contributes to the problem that is the ongoing sexualisation of women. The Purity Myth: How America's Obsession with Virginity is Hurting Young Women. (California: Seal Press, 2009). Pg 64.
} 
However, Sandra Lee Bartky has pointed out that shame, (not merely dissatisfaction with appearance), which she characterises as a 'species of psychic distress occasioned by a self or state of the self apprehended as inferior, defective, or in some way diminished,' is characteristic of a female feeling life. ${ }^{257}$ Bartky points out that women in general are not as assertive as men, have lower self esteem, and less confidence. ${ }^{258}$ A female may be viewed negatively when displaying masculine traits such as ambition and assertiveness. ${ }^{259}$ In relation to the body, Bartky refers to the fashion-beauty complex as encouraging narcissism in women, stating that never ending images of female beauty remind women constantly of their failure to measure up. 'Every aspect of my bodily being requires attention or else heroic measures merely to conserve it. ${ }^{260}$ Woman must exist at a distance from her body - scrutinising it constantly in a disapproving manner. ${ }^{261}$ This bodily preoccupation not only has financial consequences for women, (gym memberships, spa treatments, makeup, not to mention the growing popularity of cosmetic surgery procedures all cost a lot of money), but also health consequences - mental and physical. While I believe it would be simplistic and wrong to reduce eating disorders like anorexia and bulimia, which disproportionately affect adolescent girls, to being simply the result of the influence of media images, it is nevertheless true, as Susan Bordo has noted, that 'fat has become a symbol of laziness and a lack of willpower,' while industries centering on body enhancement are glamorised. ${ }^{262}$ The slender body is an ideal of a 'well managed self' - a 'metaphor for the correct management of desire.'263 Although, for instance, anorectics may be classed as physically abhorrent and deviant, in actuality, they adhere to cultural rules and values in an extreme

\footnotetext{
${ }^{257}$ Bartky, Sandra Lee. 'Shame and Gender.' In Femininity and Domination: Studies in the Phenomenology of Oppression. (New York: Routledge, 1990). Pg 85.

${ }^{258}$ Ibid. p. 88.

${ }^{259}$ Ibid. p. 91.

${ }^{260}$ Bartky, Sandra Lee. 'Narcissism, Femininity and Alienation.' In Femininity and Domination: Studies in the Phenomenology of Oppression. (New York: Routledge, 1990). Pg 40.

${ }^{261}$ Ibid. p. 40.

${ }^{262}$ Bordo. Susan. Unbearable Weight: Feminism, Western Culture and the Body. (Berkeley and Los Angeles: University of California Press, 1993). Pg 11.

${ }^{263}$ Ibid. p. 201.
} 
manner, ${ }^{264}$ disturbingly excelling and surpassing expectations that women must make herself small and vulnerable. Everyday, women are bombarded with advertisements that aim to capitalise on female gender shame through promises that buying certain products will make us younger, thinner and more desirable.

While it may seem like a jump to go from discussing a small body of films to briefly drawing attention to the wider social context of shame and gender, nevertheless it is important that I do so in order to display the limitations evident in the construction of shame in the makeover film and its larger and more insidious reality. While girls may indeed behave the way they do in the teen makeover film from time to time, I believe that the teen makeover film places blame for the policing of femininity onto a small group of influential mean girls who must be stopped, thus separating the problems from their patriarchal origins. In fact, it must be reiterated, that most makeover films encourage male policing of femininity but not female policing of femininity through the central makeover trope. The films also detract from the real and serious problem of debilitating gender shame by displaying it to be a manipulative artificial construct of these same girls, who are dedicated to a postfeminist lifestyle.

Bartky writes of women living their lives in a constant state of self judgment as seen by an anonymous patriarchal other. ${ }^{265}$ In the teen makeover film, judgment of the female body by males is often encouraged, while the female preoccupation with their own bodies, and other female bodies, is shown to be a construct of the manipulative female mind. An embodied female other is responsible for lowering the self esteem of other females, and it is she who contributes to the demasculinisation of man through her manipulative power plays. Male sexual objectification of girls, which contributes to females viewing their bodies as objects, in the makeover film does not often occur with negative consequences.

\footnotetext{
264 Ibid. p. 203.

${ }^{265}$ Bartky, Sandra Lee. 'Foucault, Femininity and the Modernization of Patriarchal Power.' In Writing on the Body: Female Embodiment and Feminist Theory. Eds. Katie Conboy, Nadia Medina and Sarah Stanbury. (New York: Columbia University Press, 1997). Pg 140.
} 
Unsavoury male characters like Joey in 10 Things I Hate About You and Josh in The Princess Diaries are shown to be far more preoccupied with their own appearances than with the bodies of girls. An exception to this is Dean in She's All That, who comments on Laney's breasts early in the film and later attempts to rape her. However, Zack's objectification of Laney is vindicated in this film as the makeover he orchestrates is shown to contribute to her newfound greater sense of self worth. In fact, in The Princess Diaries, the objectification of the female body is initiated by female antagonist Lana when she tricks protagonist Mia into getting undressed in the presence of a camera. This is also true of the example I discussed earlier from Mean Girls where a mother takes sexualised photos of her daughter.

The males in the teen makeover film are further absolved from guilt by displaying their dissatisfaction and frustration with the female antagonists' shallowness, i.e. their preoccupation with appearance. A recurring male character in these films is the male in danger of impotence through his association with the aggressive deviant female, who has become this way through her adherence to the postfeminist masquerade, which she utilises to disguise her bid for domination. This male is jaded with the 'new' body-fixated girl, and longs for someone who is more natural and real. He can be seen in the characters of Austin in A Cinderella Story, Zack in She's All That and Aaron in Mean Girls. These males are presented as victims of the girl who solely concentrates on appearance to get her own way, not because she feels she must look a certain way in order to be noticed at all. Obviously, men are indeed complicit in the policing of the female body, and when they do so in the makeover film it is shown to be necessary. The association of women as body has patriarchal roots of course, with women defined as male property, ${ }^{266}$ but it is impossible to ignore, for instance, the overt sexualisation of women in magazines aimed at both adolescent boys and older males, ${ }^{267}$ and the prevalence of television programmes centred around the reconstruction of female bodies to fit male standards of beauty (Extreme Makeover, The Swan, Dr 90210).

\footnotetext{
${ }^{266}$ Weitz, Rose. 'A History of Women’s Bodies.' In The Politics of Women’s Bodies; Sexuality, Appearance and Behaviour. Ed. Rose Weitz. (Oxford and New York: Oxford University Press, 2003). Pg 3. ${ }^{267}$ Gill, Rosalind. Gender and the Media. (Cambridge: Polity Press, 2007). Pg 211.
} 
Susan Bordo has written about the fact that on the show 20/20, ten-year-old boys proclaimed slim fashion models (who were posing so that a 'small bulge of hip was forced') to be fat. ${ }^{268}$ She also notes that men are more likely to say it is important that their partner be slim, while women are more prone than men to perceive themselves as too fat. ${ }^{269}$

I am not attempting to say that men solely exert a power over women in everyday life, but that the monitoring of the female body and the feelings of gender shame in regard to appearance are born out of a complex patriarchal ideology that privileges men. Portraying males to be the victims of the narcissistic female and undermining the real shame experienced by girls and women is indicative of the patriarchal ideology that is evident in the teen makeover film. When Austin expresses delight that Hilary Duff's Sam would rather eat Big Macs than rice cakes in A Cinderella Story, saying he 'likes a girl with a healthy appetite,' the message that comes across is that males are tiring of the female preoccupation with appearance, as exhibited by the female antagonists. However, Austin also sniggers when an overweight girl from his class proclaims to be his Cinderella, so the message is that one must look like an all-American pop star but must not disclose the effort it takes in order to look like this. One should be naturally slender and beautiful, humble, passive and gentle, but should never refer to the artifice of femininity. In fact, the makeover is a gift for those who are naturally beautiful underneath their ugly signifiers. The female to be objectified, the protagonist, is a girl who apparently deserves the pleasures of objectification, the makeover a tool allowing her to be recognised. The teen makeover film participates in what Iris Marion Young has called a misogynist mythology that 'gloats in its portrayal of women as frivolous body decorators. ${ }^{270}$

\footnotetext{
${ }^{268}$ Bordo, Susan. Unbearable Weight; Feminism, Western Culture and the Body. (Berkeley and Los Angeles: University of California Press, 1993). Pg 187.

269 Ibid. p. 204.

${ }^{270}$ Young, Iris Marion. 'Women Recovering Our Clothes.' In On Female Body Experience: Throwing Like A Girl And Other Essays. (Oxford: Oxford University Press, 2005). Pg 68.
} 
In this chapter I hope to have illustrated that the deviant females in the teen makeover film are so for the way in which they appropriate a postfeminist masquerade in order to gain social control. The overtly feminine masquerade is worn to present a reassuring façade, a trap that is used to ensnare male victims who are then situated in a dependent position to these characters, robbed of an active masculinity that must be reclaimed. The masquerade is presented as integral to the power of the antagonists. Female gender shame in relation to the body is encompassed within this masquerade, presented as an artificial construct of the female mind designed in order to gain superiority over other females. The policing of the female body in the teen makeover film is divorced from its patriarchal origins, and transferred onto the mean girl. Furthermore, the female preoccupation with idealised beauty is shown to be something males are tiring of, something that they themselves are victims of. Strangely, the teen makeover film promotes the idea that idealised beauty is necessary in order to invite desire, but it should always reflect the inner beauty of the self and should not require constant upkeep and monitoring by females themselves. Certainly, it should never be used to manipulate. 


\section{Chapter Four: The Last Kiss and the Romantic Resolution}

In many a teen makeover film, it is the final kiss that concludes the narrative. The final kiss, like those in ancient fairytales, indicates that the hero and heroine have overcome the obstacles that have threatened their true and pure love. The kiss is a moment of symbiosis for two manifestations of idealised gender types, and acts as the solution to an equation that cancels out other undesirable possibilities for the narrative's conclusion. In the teen makeover film, this scene aims to show its viewer that the love that has grown between the male and made-over female is a realm of possibilities due to its all-conquering power. It can command nature - it will bring fertility and wealth. The kiss is a culmination of the hard work involved in training the protagonist in gender performance and minimising the wayward aspects of her character. It functions as a symbol of the fact that she can now invite desire, having become a correctly gendered female, and marks the beginning of a new promising future for her that has its basis in an idealised couple.

And yet, the final scene in which this powerful, (and supposedly empowering), kiss takes place, typically contains a verbal exchange that precedes it. This brief verbal stream of consciousness, usually uttered by the female, is cut short, interrupted by the greater force of the final kiss that cements her place as half of a romantic partnership, and which is based on her newfound status as object of male desire. When the made-over female speaks in this scene, prior to the interruption, she speaks in a manner that is reminiscent of her status before the makeover. That is, she reminds us of her link to the cerebral - a link which helped to characterise her as deviant before this undesirable trait was minimised. In this scene, the association with the mind is rendered empty and meaningless. A resignification occurs in which we are shown that the protagonist's speech is not a matter for concern, it is a personality quirk that can be silenced through a kiss, which some 
commentators have termed an 'erotic gag. ${ }^{\text {,21 }}$ In this chapter, I will look in depth at the final scenes in the teen makeover film, scenes that traditionally utilise the last kiss as a means of narrative closure and as an assurance of the validity and power of the central heterosexual relationship. I will study how this power is illustrated, before looking at how the last kiss has previously been analysed. Then I will analyse the interruption of speech with physical expression, with the aid of Judith Butler’s work in 'Excitable Speech: A Politics of the Performative.'

\section{The All-Powerful Last Kiss}

The last kiss in the teen makeover film can take place in a variety of different settings, although it generally comes about as a resolution to a final conflict or obstacle to the central idealised romantic pairing. In She's All That, the kiss takes place outside Laney's home, where her father has attempted to make the moment special by lacing the backyard with fairy lights. Laney has just escaped from the unwelcome advances of Zack’s friend Dean, who she went to the prom with upon discovering that she was a pawn in Zack's bet. However, in this scene, Laney appears to embrace her swan makeover by referring to herself as like Julia Roberts in Pretty Woman, her previous anger dissipating.

As in She's All That, the lead duo in The Princess Diaries are dressed in finery for their final kiss, connoting their status as royalty - elevated above the masses. It takes until this scene in The Princess Diaries for Mia to be able to move in a manner befitting of her station as a Princess. It would seem that this is because Mia does not get together with her ideal mate until the end of the film. Mia gets her desired 'foot popping kiss' at the conclusion to the movie. The movement of her foot accidentally flicks a switch, causing the gardens to light up and the fountains to be brought to life. This pairing is then marked as one of truth and promise, bringing light to a previously darkened world through a relationship made possible by an idealised, white, gender trained feminine body. It has to be

\footnotetext{
${ }^{271}$ Radner, Hilary. Shopping Around: Feminine Culture and the Pursuit of Pleasure. (New York and
} London: Routledge, 1995). Pg 75. 
noted that Mia's previous attempt at a foot popping kiss was in a darkened shed, her foot becoming trapped in netting, unable to 'pop.' Fate would not allow the previous pairing of Mia and Josh, the latter being a boy who has privileged his body over his soul, thus putting him in a feminine position. ${ }^{272}$ Josh was only interested in Mia's newly beautified appearance and status, neglecting to notice the inner feminine core to be cherished.

In an even more hyperbolic fashion, the final kiss in A Cinderella Story is actually able to break a long-running Californian drought. The romantic pairing here is dependent on Sam’s 'Prince Charming' Austin choosing writing as a career path, (a life of the mind), over football, (a life of the body). After confronting Austin with the line, 'waiting for you is as useless as waiting for rain in this drought,' Sam waits in the stands for the final time for Austin's decision. His decision to quit playing the game and run up to meet Sam climaxes in a crane shot where the heavens open and rain pours onto the unsuspecting couple's awed faces. As in The Princess Diaries, this scene indicates more than simply a resolution to a teen love story, it operates as a seal of approval for the central couple to go forth and procreate. Even Ten Things I Hate About You, which has less of a fairytale-like quality to it than some of the other films here studied, opens and closes with shots of the school from the sky - the pupils below looking like a mass of dots until the focus zeroes in or away from the key characters. These characters here are somehow marked from above as being destined to benefit from the inevitable happy ending to the romantic story. ${ }^{273}$ However, to become worthy of this happiness, change has to occur.

These final scenes are ones of victory. The central female character, once on the outskirts of social life, has become desirable as a result of a physical and/or social

\footnotetext{
${ }^{272}$ Elizabeth V Spelman explains Plato's view that for a male to pay more attention to his body than to his soul is for him to act like a woman in 'Woman as Body: Ancient and Contemporary Views.' Feminist Theory and the Body: A Reader. Eds: Janet Price and Margrit Shildrick. (New York: Routledge, 1999).

${ }^{273}$ Diane Negra discusses the destiny trope in chick flicks, explaining that the filmic characters often discover that fate has already chosen their life path for them in What a Girl Wants? Fantasizing the Reclamation of Self in Postfeminism.(London and New York, Routledge, 2009). Pg 7.
} 
makeover that is presented as allowing her to reach her full romantic potential. The makeover may have been conducted under dubious pretences, but the motives are all but forgotten as the male realises that the lovely exterior is a match for the commonly nurturant feminine core - values which are shown to have become a rarity in consumer-driven, postfeminist times. It is this validation by the male character of the new and improved female body and mind that allows the makeover protagonist to transition from girlhood to adulthood.

\section{The Last Kiss as Coming of Age}

In 'Romancing the Girl: Adolescent Romance Novels and the Construction of Femininity,' Linda Christian-Smith provides a useful starting point from which to analyse the conclusion to the teen makeover film. While I have discussed the teen makeover film as largely influenced by popular myths and fairytales, ChristianSmith here makes observations about the teen romance novel that reflect evident values, practices and a dominant ideology in the movies studied here.

Christian-Smith writes that in the adolescent romance novel, love is signified through a chaste kiss, and it is through this love that a coming of age occurs. The young girl, described here as 'uncertain,' is taken into the poised world of female adulthood. ${ }^{274}$ Interestingly, Christian-Smith describes the code of romance as a 'market relationship,' with romance being a transforming experience for the girl involved, as it gives meaning to her life and endows her with prestige. ${ }^{275}$ For her part of the bargain then, the girl offers fidelity and devotion in exchange for this support and prestige. ${ }^{276}$ By becoming a 'girlfriend,' the female in the romance novel becomes male property - 'feminine power is confined to an informal system of persuasion, fragility, helplessness. ${ }^{, 277}$ Like the teen makeover film, ChristianSmith notes that adolescent romance novel heroines are commonly weak and shy,

\footnotetext{
${ }^{274}$ Christian-Smith, Linda K. 'Romancing the Girl: Adolescent Romance Novels and the Construction of Femininity.' In Becoming Feminine: The Politics of Popular Culture. Eds: Leslie G Roman, Linda K Christian-Smith and Elizabeth Ellsworth. (Sussex and Philadelphia: The Falmer Press, 1988). Pg 80.

${ }^{275}$ Ibid. p. 81.

${ }^{276}$ Ibid. p. 82.

${ }^{277}$ Ibid. p. 85.
} 
in contrast to what she calls the 'other girl' - the antagonistic character. She points out that while heroines became stronger during the period of second wave feminism, their characterisation regressed into old patterns again in the 1980s. ${ }^{278}$ Christian-Smith observes that in the romance novel, the girl learns that feminine power and initiative are not conducive to getting along in a romantic partnership. She contends: 'Since romance is ultimately about power, by having so many romances dissolve in the wake of girls' bid for power, these novels make a strong statement about the irreconcilability of feminine power and satisfying relationships with males.' 279

Although Christian-Smith is here analysing romance novels spanning from the 1940s to 1980s, and my study is of the contemporary teen makeover film, there is a marked similarity in terms of how the central character is positioned against others in the text, and what her role is in the eventual romantic partnership. It is the last chaste kiss and perhaps an accompanying dance that constitutes the beginning of the union - the bodies symbolically melded together in a way that controls sexuality in what the text perceives as a pure and civilised manner. As a result of the makeover and subsequent romantic partnership, often the girl is able to enter the social order and influence her peers. Her initial clumsiness gives way to a new literal and metaphorical sense of direction and seamless movement, and she simultaneously finds a purpose in life which does not lie in her initial passion for wayward hobbies, such as political art, (She's All That), feminism (10 Things I Hate About You), or rock climbing (The Princess Diaries). The last kiss is a culmination of the training that the makeover has instigated and in turn initiates the protagonist's path to womanhood. Like the romance novel, the romantic union in the teen makeover film is often predicated on a similar exchange of fidelity and devotion for the support and prestige associated with being partnered with an idealised male in the space of the school. It must be noted however that this

${ }^{278}$ Ibid. p. 87.

${ }^{279}$ Ibid. p. 92. 
character may be rejected due to a narcissistic concern with his own body that does not allow him to fulfil the heterosexual matrix.

If the last kiss is a culmination of the efforts of gender training, it is also the mark of feminine success for one who could not previously be categorised as feminine. The romantic partnership, the last kiss, indicates that the central girl is now a biological and gendered female who is desired by a male she initially hated or was at least wary of. Aspects of her character that situated her outside the domain of idealised womanhood come to be recognised as debilitating obstacles to her social development, although for many protagonists they were in fact tools that elevated them intellectually. The new resignified identity of the protagonist is that of one half of a romantic couple that has been tailored to better conform to hierarchical sex and gender norms.

While the tone of the scene containing the last kiss is blissful and happy for both parties involved, (sometimes an air of gratitude is also notable on the part of the female, as in She's All That), the kiss, and the union it symbolises, is based on an understanding of gender roles that are built on a power imbalance. In accordance with a postfeminist tendency to label as empowering practices that are essentially the opposite, the female is presented as now having a future based on a more true sense of self that she can only achieve through a mode of performance - by pretending to be someone she is not. The teen makeover film aims to escape this notion by conveying the idea of the waiting to be discovered hidden light, or inner ideal feminine, that can be buried due to society's faults and failures, but can also be rediscovered through moulding, shaping, and cajoling the outer layers. If the kiss is the culmination of this supreme effort, then no wonder it can seemingly set fountains going, light up yards and break droughts.

\section{The Kiss as the Erotic Gag}

As has been illustrated with the romance novel, the final kiss spans across many genres, and many different types of texts. In the makeover film certainly, but in 
many other films, books and fables featuring a core romance, the last kiss is an expectation - a staple for this kind of plotline. To create a romance story without this last symbol of partnership and union is, in effect, to play with audience expectations and possibly to change the meaning of the story. The final erotic union of the central couple has been analysed by theorists of the romance novel. However, as I will illustrate, it is also important that the final kiss here is read with specific regard to the teen makeover film, which is characteristically focused on gender performance and the manipulation of female body, mind and desire.

\section{In Shopping Around - Feminine Culture and the Pursuit of Pleasure, Hilary}

Radner hypothesises that the final sexual union in the romance novel acts as a kind of erotic gag - a method of silencing the speaking woman. In the teen makeover film, the final union is symbolised by a final kiss, governed as it is by somewhat phobic attitudes around adolescent female sexuality. However, the way the kiss is treated in the teen makeover film, as a transcendent moment rather than a mere physical act is similar to how the sexual union is written about in the romance novel. ${ }^{280}$ Radner's analysis is both of text and reader, while my study is of the text and its relationship to society. However, Radner's analysis links the textual protagonist and reader in a manner which impacts on how she chooses to analyse the final union in the novels. Radner points to the textual representation of the romance as constructing a language for women which is silent, citing fairytale examples of the girl who waits, for instance Snow White and Cinderella. In contrast, a woman who wanted to be heard would be shrewish - unfeminine. ${ }^{281}$ She utilises Shakespeare's The Taming of the Shrew, the play on which teen film 10 Things I Hate About You is based, in order to illustrate the rejection of a feminine position symbolised by a character that dares to speak her mind. In order for Kate to become part of a romantic union, she has to relinquish her 'mastery of language as a site of production through which her desires can speak. 282

\footnotetext{
${ }^{280}$ Radner, Hilary. Shopping Around - Feminine Culture and the Pursuit of Pleasure. (New York and London: Routledge, 1995). Pg 73.

${ }^{281}$ Ibid. p. 13.

282 Ibid. p. 20.
} 
Hilary Radner chooses to read the final union in the romance novel psychoanalytically, writing that fulfilment for women in the romantic text, signified through this symbol of romantic union, requires that they return to a prelinguistic state where there is no distinction between object and self. There is the 'reinscription of a primal regressive tendency in the subject who wishes to efface the trauma of absence and division by returning to a stage that precedes the symbolisation of language. ${ }^{283}$ In this manner then, Radner compares the final relationship to that between mother and child, in that the male partner must nurture the female, and in fact act and speak for her. Janice Radway, quoted by Radner, believes the romantic scenario depends upon the feminine desire to be the object of the nurturant, effeminate attention of a spectacularly masculine hero. ${ }^{284}$ The desire of the reader correlates to the desire of the protagonist. Radner, however, although not disagreeing with this description of the male, believes Radway and other theorists on the romance to have ignored the figure of the silenced shrew in these accounts, and to have failed to situate this figure, and the reader, within the masochistic scenario. The final erotic union then, in its privileged position over language, connotes a fulfilment of a feminine desire to be the object of this attention. However, it is necessary for the central character to sacrifice speech in order to achieve a symbiosis with this nurturing hero. Though Radner states in summary that the romance 'may not originate in the desire to obliterate the self,' she does not read the texts outside of a masochistic paradigm that relies on the eroticisation of male domination within the masochistic scenario. This scenario is discussed as an alibi for the female reader, who can experience the masochistic scene within a protected arena of fantasy, situating the shrew in an erotic rather than socio-economic context. ${ }^{285}$ It could perhaps be argued that Radner's psychoanalytic theory of the erotic union could be applied to many a romance movie made in postfeminist times, and indeed to many films with a romantic plotline since the beginning of cinema. However, while I believe that the

\footnotetext{
283 Ibid. p. 75 .

${ }^{284}$ Ibid. p. 86.

${ }^{285}$ Ibid. p. 94.
} 
last kiss does in fact silence a speaking woman who may speak for herself, I believe that this theory would overlook the complexities of the texts I am studying in significant ways.

Theories accounting for female masochism are divided. For instance, early psychoanalysts believed that female masochism was instinctual, a result of the 'change in libido from an earlier active-sadistic cathexis to a passive-masochistic investment in the vagina. ${ }^{286}$ Helene Deutsch believed that because the main events in the sexual lives of women were painful, feminine masochism was necessary for the preservation of the species. Feminists tend to favour another argument that believes because women are taught to be more inhibited and guilty about their sexual desires than men, they therefore are more prone to masochism ${ }^{287}$. Hence a reading relying on a theory of female masochism can be problematic in that one has to pick and choose exactly what theory one privileges. Radner uses Studlar and Deleuze to state that the female child takes up the same position in relation to the oral mother as the male child. ${ }^{288}$ The feminine masochistic tendency is discussed in relation to this phase for both characters within the text and female romance readers. It therefore has its grounding in a perceived truth, even though this truth may be exploited by the patriarchal text. This psychoanalytic reading obviously works for Radner's analysis of the romance, but it comes with the erasure of other theories of feminine masochism from a feminist perspective that can better account for why women are more prone to masochism in the first place. Radner's analysis does not aim to recuperate the texts from studying the position of the female reader, as does Radway's. However, in its reliance on psychoanalysis, the study still looks at the romance texts disproportionately in terms of how they aim to satisfy a female masochistic desire to be completely cared for and nurtured, rather than studying the text as a product of a patriarchal society that may force aspects of feminine

\footnotetext{
${ }^{286}$ Bartky, Sandra. Femininity and Domination: Studies in the Phenomenology of Oppression. (New York and London: Routledge, 1990). Pg. 52.

${ }^{287}$ Ibid, 53.

${ }^{288}$ Radner, Hilary. Shopping Around - Feminine Culture and the Pursuit of Pleasure. (New York and London: Routledge, 1995). Pg 82.
} 
desire into certain manifestations, and/or which may aim to manipulate this desire in a manner that benefits this same society. Although the reader, according to Radner, is forced to identify with the woman to be silenced, to not study the text or reader outside of the pre-Oedipal phase is to restrict the analysis in the same way that the text perhaps restricts the reader.

To perceive the last kiss as a moment of symbiosis between mother and child in the teen makeover film would be to place far too much emphasis on the nurturing propensities of the male hero and to disavow the fact that the teen protagonist is commonly chosen for the makeover because she herself exhibits a nurturing character. Although it is necessary for the female character to become reliant on the union that is the final partnership, this is not because she has become, and forever will be, infantile. The teenager, in part due to her age and in part due to the new values that she has come to signify, represents a better and brighter future. In having the last kiss bring fountains to life and rain to dry land, fertility is promised for the partnership. Although the female position more generally is characterised by passivity and fragility, and it is tempting to read this position solely as childlike, it is important the teen makeover protagonist is shown to prefigure the nurturant idealised mother. The makeover primarily takes place so that the female can invite male desire. This idealised couple is an idealised parental couple. To say that in the teen makeover film, woman becomes the child, would be to place the character in a dependent, but simplistic and problematic position when one considers the more complex gender politics of the text.

The female makeover protagonist is spoken for, but in a manner that has certain implications for the society within the film, and, as the film functions as a type of moral cautionary tale for its viewers, the society outside it. The text could indeed satisfy a feminine masochistic desire, (although this 'desire' is not an unproblematic one), on the part of the character and the viewer, but this satisfaction comes with the acceptance of rules on the part of the makeover protagonist. She has to acquiesce to follow certain formulae for the feminine in 
order to fulfil her destiny. The trained gender performance of the key character in the teen makeover film is integral to her success. What she symbolises and signifies at different stages in the text is crucial to a reading of how she is integrated into patriarchal society.

Because of the importance of gender performance in the teen makeover film, it would not be unproblematic to say, as Radway has done, that the male hero is nurturing and effeminate, and that this characterisation is the result of a female fantasy that wishes he be so. While a deeper study of the male character is beyond the scope of this thesis, which aims to primarily focus on the representation of female adolescence, I would be reluctant to say the male hero is feminised. Certainly he becomes more protective of the female protagonist, who often becomes increasingly more vulnerable as she trains in femininity, but this may be in fact a method of ensuring that she does not regress into old habits.

Kathleen Rowe, has cautioned against hailing romantic heroes who learn sensitivity during the course of a film, as they may only do so in order to prop up their own patriarchal authority. This differs from readings that study a male/female hybrid hero as a female fantasy figure that its origin in the prelinguistic phase. Feminised genres, femininity or feminism can be invoked by this hero in order to instruct women about relationships and romance, and even femininity itself. It is possible that the formulation of this hero exploits a masochistic fantasy, but it is important to recognise this exploitation and how this exploitation occurs in the texts. These lessons, offered by the narrative's hero, must then be internalised. As Rowe argues:

'It is his narrative function to incite a discourse about difficult or emotionally damaged women over which he must keep constant vigilance. In this process of 
defining her as wounded or inexperienced in the ways of the adult world, he can demonstrate greater wisdom, charm and sensitivity. 289

Lastly, a psychoanalytic theory of the final kiss and lasting romantic union would fail to take into account the postfeminist climate in which these films are made. While Radner points out that the romance novel may be situated in the past or set in fantastical spaces, ${ }^{290}$ the teen makeover films are always set in the present day. Postfeminist representations are evident in the characters of the deviant adolescents. The social expectations on all of the young characters are in some senses reflections of the 'real life' cultural expectations placed upon young people. To construct a relationship in which the female is completely infantile and dependent would perhaps not be received well by a young female audience who are used to being sold the girl power message through music and television. While the protagonist's wayward activities and association with the mind are minimised, and her passive and nurturing nature is held up to be idealised, it is important that, as a result of gender performance, she appears to also be empowered.

While this empowerment may be false, it is nevertheless important that this is taken into account in an analysis of the conclusion to the films. Through inviting male desire by learning to walk, talk and/or act like a woman, the central girl in most films becomes less clumsy or less awkward and shy, and is placed on the right path to achieving bigger and better things - like, for instance, running a small European country as in The Princess Diaries. As Radner's analysis points out, the protagonist is somewhat of a puppet in that she needs a male to act and speak for her, although with regard to the teen makeover film it would perhaps be more accurate to say that the protagonist is spoken for by patriarchy, rather than the 'male.' It is important to note that the makeover protagonist is manipulated and directed to become this emblem of feminine 'respectability' after it is

\footnotetext{
${ }^{289}$ Kathleen Rowe quoted by Janet McCabe in 'Lost in Transition: Problems of Modern (Heterosexual) Romance and the Catatonic Male Hero in the Postfeminist Age.' In Falling in Love Again: Romantic Comedy in Contemporary Cinema. Eds: Stacey Abbott and Deborah Jermyn. (London and New York. I.B Tauris and Co Ltd, 2009). Pg 162.

${ }^{290}$ Radner, Hilary. Shopping Around - Feminine Culture and the Pursuit of Pleasure. (New York and London: Routledge, 1995. Pg 92.
} 
demanded that she relinquish certain characteristics that initially situate her as outside of the heterosexual matrix. I believe that a psychoanalytic study of the last kiss here would overly concentrate on the figure of the hero from the position of a masochistic fantasy, without adequately explaining why and how female desire within the specific texts is manipulated in the way that it is and to what ends.

In 10 Things I Hate About You there is a scene in which the main female character completely breaks down and quite literally loses her ability to speak. She is rendered momentarily infantile. Granted, I am being extremely literal here, but nevertheless the example is an interesting one. In this film, feminist Kat, who stands out as a teen makeover film protagonist for her mastery of literary language, uses her knowledge of feminist theory to provoke and confront the school curriculum, and what she sees as certain characters' misogynist attitudes towards girls. Toward the conclusion of the film, Kat is rendered infantile through a class Shakespeare assignment. I have noted earlier that Kat initially sees Shakespeare as a symbol of patriarchal oppression, originally rebelling from partaking in class assignments. Her decision therefore to partake in this assignment represents a minimising of her feminist values. Furthermore, the poem, (clearly about her love for Patrick), that Kat writes and reads aloud to class, is not one that one would expect to be written by the class intellectual. It is a very basic rhyme, filled with repetition and slang, and suffers in its delivery through Kat's tears. The class of students which once witnessed Kat's attempts at power through knowledge, now witnesses her on display, broken and infantile as a result of a quarrel with Patrick. This is not a scene that aims to show that Kat has been left broken, empty and forgotten, however. This poem, the '10 Things I Hate About You' of the title, and the display of vulnerability that accompanies its reading, leads Patrick and Kat to reconcile through the last kiss. The poem is a symbol that Patrick has managed to penetrate the artificial hard walls that Kat has built around herself. It is Kat's feminism, which in this film is coupled with her man-hating and aggressiveness, that constitutes these walls, and it is this feminism 
which has to be shattered in order to get to the 'real' Kat - who, as I have discussed, in Chapter Two, is in fact nurturing, caring and vulnerable.

Kat is only rendered infantile, virtually unable to speak, for a short moment in time. Kat is more aggressive and more knowledgeable in her bid for power than most teen protagonists studied here, who are 'accidentally' threatening. Therefore, it makes sense that Kat's moment of enlightenment, and simultaneous destruction of her belief system, is more pronounced than it is for characters in some other films. It is a moment that precedes the last kiss, where in many films speech is interrupted in favour of an expression of love - and it is this moment that I wish to now concentrate on. The interruption of speech with a kiss is, as Radner points out, a type of gag, but it is perhaps best for this particular group of films if it is not read psychoanalytically.

\section{Female Language and Interruption in the Teen Makeover Film}

In order to understand the last kiss in the context of the theoretical framework for this study, the interruption of speech with the act of the kiss must be analysed. It is the context, tone and nature of the language chosen by one body to construct the speech that is significant in films which aim to train girls in gender performance, and it is this ideological significance which can only be discovered following a thorough analysis of the characters involved, their narrative progression, and the place of the story in social context. If the kiss commonly comes about as a result of an interruption of language, what does this language represent for the kiss, and what does the act of interruption in favour of it mean for depicted gender relations? While this interruption does not occur in every film, the silencing of the speaking person in the teen makeover text is certainly a common enough occurrence.

In The Princess Diaries, Mia and Michael engage in conversation at a royal dance prior to the 'foot popping kiss.' Mia becomes detached from the conversation, looking at the sky rather than Michael, verbalising a stream of consciousness 
about how she is still the same person despite becoming royal. Here, she is cut off from speaking with the kiss, which sets off the lights and fountains, and subsequently she is drawn back into the moment and the matter at hand. In 10 Things I Hate About You, after Kat's poem temporarily leaves her vulnerable and infantile, Kat and Patrick reconcile in the school car park where Patrick presents her with a guitar in a bid to make amends for his bad behaviour. Kat is visibly thrilled, but then aims to pick an argument with Patrick over the fact that he appears to believe that he can buy her off every time there is conflict. Patrick laughs off Kat's pseudo-aggression and silences her with the final kiss. In She's All That, the lead pair dance in formal wear at Laney's house and Zack jokes about being dragged along by Laney to performance art. Here, Laney instigates the interruption by commanding Zack to shut up and kiss her. Although there is no explicit interruption of speech with a kiss in A Cinderella Story, Sam still expresses surprise at Austin's actions prior to the final embrace, as he leaves from playing a football game in order to run up into the bleachers and meet her.

In the first three examples, the speech that is interrupted refers to the initial waywardness of the protagonist - Mia's goofiness and inability to do the right thing at the right time, Kat's aggressiveness and Laney's love of art. It could be argued that in this articulation of speech at the final moments in the films, the texts are reassuring us that despite attempts to make over female characters, they really are the same people. The newfound exterior beauty, (more apparent in Mia and Laney than Kat, who undergoes only a subtle physical change), has not altered the true essence of the person. Instead, the makeover has simply brought love to the lives of the protagonists, and in the case of Mia, Laney and Sam, added confidence. The happiness and confidence that come with the makeover are important to the film's message of empowerment as resulting from inviting desire. This is synonymous with postfeminist discourse, and yet the films' protagonists are usually rewarded with the makeover for pre-feminist traits. 'Power' then is channelled into a future that benefits heterosexuality and a patriarchal system, and 
empowerment is primarily brought about by subscribing to this system both through the exterior and interior body.

However, to claim that these protagonists still carry their initial wayward characteristics and the makeover has simply served to make them more confident, would be to ignore the re-signification that these traits have undergone. These traits are no longer threatening in the final scenes, but are aspects of character to be joked about. To claim the former would be to ignore the fact that speech is here deemed secondary to the kiss, which usurps language through interruption.

Judith Butler in Excitable Speech: A Politics of the Performative,' in likening her theories on bodily performance with the effects of language on the constitution of the subject, states that language sustains the body. The body is interpellated within language terms, and because of this, a social existence for the body becomes possible. ${ }^{291}$ While Butler's book is primarily an analysis of hate speech in society, I believe that the writing which forms the introductory pages of her book is helpful for a study into how certain textual characters signify as a result of the scripted language interruption scenario. It will not be my intention to argue, as Catherine A MacKinnon has done through a study of pornography in Only Words, that this scene in the teen makeover film constitutes an idea that consumers will later want to 'live out. ${ }^{292}$ In analysing a speech act in the teen makeover film, I will not read the scene as speech. The conclusions to these films do present an idealised relationship built on a hierarchical sex and gender order that privileges the male, but I do see this as a textual representation rather than an act involving speech that does what it says - i.e. through the substitution of female character for female viewer, the scene acts on her in discriminatory ways. Rather, reading the makeover film is to read a body of films that can be analysed as part of a wider,

\footnotetext{
${ }^{291}$ Butler, Judith. Excitable Speech: A Politics of the Performative. (London and New York: Routledge, 1997). Pg 2.

${ }^{292}$ Catherine A MacKinnon argues that pornographic texts should be considered a form of speech, hate speech to be exact. She calls for legislation surrounding this form of 'speech,' as these texts act on women in injurious ways directly through their creation, but also indirectly through the effect they have on male consumers. Only Words (Cambridge: Harvard University Press, 1993).
} 
broader patriarchal power structure that encourages the measurement and judgement of the female body within its own terms. In studying the speech act within one scene, I am studying how it is integrated within what I believe is the dominant ideological 'message' of the films, rather than what it 'does' to the viewer. To do the latter would be to localise blame for an issue that is much more complex. ${ }^{293}$ I will be looking at the language in this scene in terms of how it constitutes the fictional filmic subject, and how the social existence of the fictional body is constructed.

Many, due to societal conventions dictating polite practice, might consider the interruption of speech to be rude - to be an indication that the interrupter believes that their speech deserves to take precedence over another's. An interruption could be said to be a form of verbal insult, despite the fact that this insult does not take the form of name calling. Judith Butler writes in Excitable Speech: A Politics of the Performative however, that linguistic injury is not only the effect of words, but of the mode of address itself. ${ }^{294}$ If speaking is a bodily act, then the body acts through what it says, ${ }^{295}$ and assumedly how it says it. In films of course, each word is carefully chosen by its writers, who are influenced not only through their cultural construction like all of us, but are constrained by genre, time and audience expectation to name but a few factors. These 'creators' aim to have each speech act relate to the characters themselves, their development and to their foregone conclusion, with each line having to be significant and deliberate. Therefore, filmic bodies are more deliberately chosen to act through speech in terms of the context, themes and meaning of the story, which is significant when one considers the (perhaps arguably) non-scripted nature of everyday conversation. In taking this into consideration, one can assume that the speech in the teen makeover film and the interruption are carefully chosen in order to convey a particular meaning.

\footnotetext{
${ }^{293}$ Judith Butler criticizes MacKinnon as figuring pornography as a subject that speaks, and in speaking 'brings about what it names,' in Excitable Speech: A Politics of the Performative. (London and New York: Routledge, 1997). Pg 69.

${ }^{294}$ Ibid. p. 2.

${ }^{295}$ Ibid. p. 10.
} 
While to be interrupted to many would be to be insulted, in the teen makeover film, the scenario is staged so that a different meaning is conveyed in accordance with the particular gender politics of the story. The mode of address for the interruption is altered from its dominant cultural understanding as being an unwelcome and impolite act. As Butler points out, an offensive utterance, (or here the offensive act of the interruption), can be restaged or resignified. It can acquire new contexts. ${ }^{296}$ Both the speech act and the interruption in the teen makeover film acquire new meaning in terms of their associations in the story and association within society respectively. When Kat argued in 10 Things I Hate About You, this was seen as result of her feminist beliefs - she was railing against what she perceived to be an oppressive patriarchy. After the moment in which she breaks down, reading her poem for a class Shakespeare assignment, she becomes a 'new Kat,' or perhaps more accurately, her old pre-film self is resurrected. As a result, her final argumentative speech at the conclusion to the film can not be read in the same manner as in the first act of the story, due to Kat's character progression which involves a minimising or taming of her deviant traits. Kat's argumentative speech at the conclusion to 10 Things I Hate About You is not delivered with the same anger and hostility as it would have been prior to her social makeover. The joyous expression on Kat's face and the upbeat music which accompanies the scene is alone enough to convince us of the fact that she is not arguing out of anger. Having Kat argue in this scene does serve to remind us of her initial waywardness, but the change in tone and situation serves to remind us of her change in character rather than to reassure us that she is the same person. Her bickering will now be part of ritualistic faux quarrels - a 'cute' character trait that is now devoid of aggression, certainly devoid of a political viewpoint, and as such is an empty threat. ${ }^{297}$ Kat has indeed been tamed. The resignification of speech here is a primary indicator of the success of this social makeover.

\footnotetext{
${ }^{296}$ Ibid. p. 13.

${ }^{297}$ Ariane Balizet notes that in 10 Things Kat's eccentricities are acceptable only in friendly competition with Patrick's in 'Teen Scenes: Recognizing Shakespeare in Teen Film.' Almost Shakespeare: Reinventing His Works for Cinema and Television. Eds. James R Keller and Leslie Stratyner. (North Carolina: McFarland and Company, 2004). Pg 130.
} 
In a similar manner, Mia's clumsy speech, (once coupled with her awkward physicality), informing Michael that she is still the 'same person,' comes after we have seen her confidently and eloquently dance in Princess attire at a royal ball. She is the incarnation of a European Princess, dressed to resemble the icon of 'class' Audrey Hepburn, not the clumsy, awkward and supposedly unattractive Mia we saw at the start of the film. Her body is clearly more disciplined and refined, made much more so with the arrival of dancing partner Michael, and while her speech here is reminiscent of pre-makeover Mia, it does not serve to characterise her as deviant or wayward, as the makeover has aided in her confidence and set her on the path to being a European royal figurehead. The speech act is certainly resignified in terms of tone, situation, of what the audience knows of the story so far, and through the interruption. But it is important that the interruption is not one of speech overlaying the speech of another. The speech, usually of the protagonist, is not cut short in the midst of a debate, but with a kiss. In most teen makeover films, the makeover takes place in order to turn the female into an object of desire. If this is not the primary aim of the makeover, it is almost always an after effect of the event. A common initial threat of the protagonist is that she can, knowingly or unknowingly, speak for herself in a manner which is not perceived as healthy for the romantic relationship. The interruption of a kiss, the physical symbol of romantic love, cuts off the conversation in a way that puts the girl in her place as object of romantic desire in a manner that she does not perceive to be injurious because her desire has been redirected to primarily want this attention. The act of interruption is not injurious due to the fact that the girl now realises that the changes she has undergone are for her romantic and social benefit. She has internalised the patriarchal gaze that is commonly initially resisted; she has been judged and judged herself, and engaged in a mode of performance that over time becomes naturalised. There is now a contract of understanding, and this accompanies the interruption - an interruption that has been headed towards and so is not really unanticipated as an interruption commonly is. Like the makeover itself, the kiss is an act of censorship, while simultaneously being an act of love. Although in this 
instance, the protagonist agrees to be censored, and perhaps even invites it as in She's All That.

Elaine Scurry has written that the threat of violence is a threat to language 'in its world making and sense making possibility' because the body's pain is inexpressible in language. ${ }^{298}$ In the reverse, I would argue that, substituting violence for love, that language, specifically female language, in the teen makeover film is a threat to love and procreation specifically because it may have the potential to be 'sense making.' Seemingly, a female can not be connected to both body and mind in a way which is unproblematic. The kiss is about the triumph of the physical bond over a language which has now been robbed of its original significance. As a result, through rain, fountains and lights, the universe is shown to applaud this triumph.

In this chapter I have analysed the conclusion of the teen makeover film through a study of the last kiss. This kiss and the interruption which leads to it are laden with meaning for the gender politics of the films studied here.

${ }^{298}$ Elaine Scurry is quoted by Judith Butler in Excitable Speech: A Politics of the Performative. (London and New York: Routledge, 1997). Pg 6. 


\section{Conclusion}

In this thesis, I have studied the teen makeover film as a product of the postfeminist age and have analysed the narrative as a battle for a traditional idealised version of the feminine to be uncovered, resurrected and publicly validated. Using a theoretical framework with its basis on the work of Foucault and Butler, but also utilising theorists such as Angela McRobbie, Vivian Sobchack, and Sandra Bartky, I have focused on the gender training of the makeover protagonist, who has an idealised, passive and nurturing core, but must be taught to invite male desire at the outer layers of her person. Because these films are aiming to address a young audience used to being sold packaged postfeminist messages of empowerment, the manipulation of female body, mind and movement is presented as being necessary to the central character's happiness and contentment as well as for the greater good. The protagonist, however, has been coerced into a position that benefits patriarchy and the nuclear family. It is important that she is chosen to be made-over because she prefigures the nurturant self-abnegating mother, although her development has been hampered due to her upbringing in a broken family.

The postfeminist girl power icon, who may elsewhere serve as a pop cultural icon for the same viewers that the teen makeover film is attempting to address, is also represented in the text. She is cast as the antagonist to the protagonist's 'good' girl, her threat lying in her obsession with consumerism and her privileging of visibility and fame over romance. In the teen makeover film, the deviant teen utilises a feminine masquerade that conceals her true agenda in order to ensnare male victims who are then used in her power play games and robbed of their active capacities. The antagonist is portrayed as responsible for a specific policing of femininity that impacts negatively on those around her.

The makeover protagonist is re-cast at the conclusion to the texts as an object of romantic desire. Her wayward traits are re-signified as empty threats - her desire redirected towards a need for romantic love and acceptance. The makeover 
protagonist is shown to have internalised a judgmental patriarchal gaze that initially found her to be inadequate. Her performance of an idealised femininity at the outer layers becomes naturalised, but it is important that this performance is seen to be the correct 'match' for her inner self.

\section{Suggestions for Further Research}

My study of the teen makeover film has focused on the textual representation of female adolescents and how these representations can be read as a response to societal fears for the adolescent in the age of postfeminism. What I have not studied is how adolescents watching these films may make sense of these texts. Because the villains of the teen makeover film so closely resemble the postfeminist girl power icon, who is celebrated in girl culture, there is the chance that some viewers may reject the idealised traditional femininity sanctified in the films.

In her study of how female spectators relate to and remember classical Hollywood femininities, Jackie Stacey noted that women in the study group who chose to write about Joan Crawford, Bette Davis and Katharine Hepburn often remembered these stars for their confidence and power. Even though their characters may have been punished in film narratives, many of the spectators chose not to focus on this. ${ }^{299}$ Richard Dyer has also argued, following Molly Haskell, that in terms of narrative weighting within the film, performance and mise-en-scene, the independence elements of the female character may in fact be stronger than the climb-down resolution. ${ }^{300}$

The teen makeover film does aim to counteract viewer identification with the deviant female through using various methods both in casting and characterisation. By often placing a star at the centre of the narrative as the makeover protagonist, the film works to align viewers with this character as

\footnotetext{
${ }^{299}$ Stacey, Jackie. Star Gazing: Hollywood Cinema and Female Spectatorship. (New York and London: Routledge, 1994). Pg 158.

${ }^{300}$ Dyer, Richard. Stars.(London: BFI, 1998). Pg 57.
} 
opposed to the unknown playing the antagonist. It is very likely that many viewers went to see A Cinderella Story and Mean Girls because Hilary Duff and Lindsay Lohan appeared in them. When Jackie Stacey discusses female memories of stars like Davis and Crawford, it is important that these memories are of stars, and so the memories are both of the star persona in 'real life' as well as the characters they played on screen. This is not to deny, however, that the teen makeover film may possibly serve as a star-making vehicle for those playing antagonistic characters. This is true of Mean Girls, with Rachel McAdams, who played deviant teen Regina George, since appearing in such films as The Notebook (Nick Cassavetes, 2004) and Sherlock Holmes (Guy Ritchie, 2009). In this film, however, protagonist Cady 'collapses' into a deviant teen at certain points, while, in contrast, most makeover narratives aim to more forcefully segregate the two versions of femininity.

The films also work to align viewers with the makeover protagonist by letting the audience into these characters' private moments. We see them with their families and close-up shots inform us of their inner feelings. By contrast, the antagonists are usually portrayed as existing only within the space of the high school, and although we are privy to seeing what they do, we are not informed of the complex emotions and internal conflicts these characters could struggle with. The films keep viewers firmly focused on these characters' villainous bids for power and their manipulation of other characters, rather than allowing for an insight into the inner feeling life of these adolescents. In fact, the films go so far as to suggest that these characters are devoid of normal human emotion altogether. They can only love, desire and even hate in the context of the power play game, and therefore these emotions lose their validity.

Despite my reservations about the possibilities of identification with the antagonist female in the teen makeover film, an ethnographic study of how adolescent viewers may respond to these images of adolescence could take the analysis of these texts into new, unforeseen and interesting directions. 


\section{Reality Television and Makeover Culture}

My study of the teen makeover film has been read as a product of the postfeminist times, which have bred uncertainty about the media address of seemingly corruptible adolescent girls. It is important to acknowledge however, that the films I have analysed are part of a much broader representational makeover culture. This makeover culture, largely evident on reality television but also in magazines and through advertising, not only exhibits itself in discourses regarding the female body, although perhaps predominantly this is so, but in child behaviour management, remodelling the house and garden or in the transformation of businesses. There are important differences in the way the television makeover works and the way the makeover works in the teen makeover film, particularly in how consumption is represented, but nevertheless these films appeal to a culture that is obsessed with images of 'becoming. 301

As Dana Heller in 'Reading the Makeover' says, 'today’s televisual makeovers emphasise physical change and material service acquisition as the paths to genuine expression of one's inner self and better nature. ${ }^{302}$ I would add that while the makeover does promise happiness for the individual, it also operates to stabilise heterosexual desire and the nuclear family, with bodily transformation working as a form of marriage or couples counselling. In shows like What Not to Wear, Gok's Fashion Fix, Undress the Nation and 10 Years Younger, the undisciplined and commonly middle-aged female body, that which transgresses the current infantilised (excessively slim, smooth and wrinkle free) ${ }^{303}$ idealised female form comes to symbolise the woman's unhappy and despairing state. If the contestant could only have a makeover, her feelings of inadequacy would disappear and she would experience newfound success in her career and in her relationship as well as enjoy a richer social life. The hosts ridicule the contestant,

\footnotetext{
${ }^{301}$ Ford Elizabeth and Mitchell Deborah. The Makeover in Movies. (North Carolina: McFarland \& Company, 2004). Pg 1.

${ }^{302}$ Heller, Dana. 'Reading the Makeover.' In Makeover Television: Realities Remodelled. (London and New York: I.B. Tauris \& Co Ltd, 2007). Pg 2.

${ }^{303}$ Bartky, Sandra. 'Foucault, Feminism and Patriarchal Power.' In Writing on the Body: Female Embodiment and Feminist Theory. Eds. Katie Conboy, Nadia Medina, Sarah Stanbury. (New York: Columbia University Press, 1997). Pg. 132.
} 
who must lay her life (and subsequently her body) bare for them and the viewers of the show. She is taught to perform her femininity in a way that will boost her confidence, although importantly this confidence in actuality comes from fulfilling societal expectations of the feminine, and in locating female success through the body. Her importance is judged through the gazes of others, who are presented as knowledgeable as to what passes as acceptable in terms of appearance. The makeover is conducted under a controlling judgmental gaze that allows no room for transgression, rebellion or departure from what it dictates. The bearers of the gaze are vindicated when the contestant expresses her thrill at being transformed. Often the presenters will re-visit the makeover candidate after a period of time to ensure that the gaze proscribing a tonic of appropriate feminine enactment that will cure all ills has been internalised and naturalised in order to create a happily ever after. The presenter's deeds resemble acts of charity - they become fairy godmother figures.

Shows like What Not to Wear, however, only transform the female body at the outer layers. That is to say, the contestant is schooled in making certain clothing, hair and makeup choices that will benefit her, bringing her closer to society's perceptions of the ideal feminine. The female subject is able to look at herself as the potential object of desire, a state which promises success in relationships and career if she can only keep up with maintaining the façade. While predicated on many of the same principles, shows such as The Swan, Dr 90210, and Extreme Makeover aim to physically discipline the interior flesh and bone of the contestant in order to force it to conform to cultural norms. Kim Akass and Janet McCabe write that cosmetic surgery that aims to discipline the female body so that it conforms to ideals of beauty, further solidifies the notion that woman is body. ${ }^{304}$

Applying the theories of Foucault in order to better understand the current popularity of plastic surgery, Akass and McCabe note that endless preoccupation

\footnotetext{
${ }^{304}$ Akass Kim and McCabe Janet. 'A Perfect Lie: Visual (Dis)Pleasures and Policing Femininity in Nip/Tuck.' In Makeover Television: Realities Remodelled. (London and New York: I.B Tauris \& Co Ltd, 2007). Pg 120.
} 
with bodily improvement functions as a dominant cultural normalising mechanism. ${ }^{305}$ The female body is encouraged to confess everything about their physicality that transgresses cultural norms. This dissatisfaction is transformed into consumer aspiration, with the idealised feminine 'body beautiful, produced in and by American culture, functioning as a model against which the self continually measures, judges, disciplines and corrects itself. ${ }^{306}$

Marsha Cassidy traces makeover television back to 1953. Glamour Girl, she writes, turned ugly ducklings into swans, transforming female bodies through consumer products and beauty advice. The process was about advocating new norms of feminine attractiveness and sexuality. ${ }^{307}$ The show was presented in a mode which Mimi White has called 'therapeutic discourse' - confession is linked with consumer culture and social subjectivity. ${ }^{308}$ As Cassidy contends, 'In the lexicon of Glamour Girl, the mark of social misfortune, inadequacy, dissatisfaction or abuse was the 'unattractive' body, presented for close inspection by the television camera. ${ }^{309}$ Commonly, the television makeover served to help contestants gain or regain an erotic appeal that ensured success in husbandhunting or husband-keeping, ${ }^{310}$ although Cassidy partially re-appropriates the programme in terms of feminine discourse by pointing out that it authorised 'girl talk' on television. $^{311}$

From 1953 to present day, the format and goals of the makeover show have not changed dramatically. Dana Heller has noted that, like Glamour Girl, where a female body came to stand in for a particular social issue, makeover television today seeks to reform individual bodies in accordance with cultural ideals,

\footnotetext{
${ }^{305}$ Ibid. p. 122.

${ }^{306}$ Ibid. p. 122.

${ }^{307}$ Cassidy, Marsha. 'The Cinderella Makeover: Glamour Girl, Television Misery Shows and 1950s Femininity.' In The Great American Makeover: Television, History, Nation. Ed. Dana Heller. (London: Palgrave Macmillan, 2006). Pg 126.

${ }^{308}$ Ibid. p. 128.

${ }^{309}$ Ibid. p. 128.

${ }^{310}$ Ibid. p. 136.

${ }^{311}$ Ibid. p. 135.
} 
creating a new ideal nation one body at a time. ${ }^{312}$ Individual advancement corresponds to societal advancement. In order to advance, through realising the true inner self, one must 'dress, decorate and desire as others do. ${ }^{313}$ In discussing Queer Eye for the Straight Guy, but making a point that could be applied to many a makeover television show, Heller argues that the show presents human/societal shortcomings as resulting not from who we are, but what we buy - how we present ourselves. $^{314}$

The makeover functions as a promise to the viewer in that these powers of transformation are also within their grasp. ${ }^{315}$ Resistance to these makeovers on behalf of the contestants is seen as weakness, a character defect. ${ }^{316}$ In reconstructing identities, makeovers act as forms of moral guidance for ordinary people who are held up to be the embodiments of an issue. ${ }^{317}$ According to Guy Redden, the makeover can lead to a form of salvation for the contestant, who initially presents signs of what kind of person they are for critique. He argues, 'performance of class, gender and potentially other forms of identity come under scrutiny through the individual. ${ }^{, 318}$

As the makeover takes place, there is an emphasis on doing what is right for the individual, as assessing the needs of the 'client' and guiding them towards consumption choices that would fit with their 'given life context." ${ }^{319}$ However, the individual as free-choosing subject is always guided through existing structures as to what constitutes correct social behaviour. In accordance with Foucault's arguments, but updating them to form a hypothesis on consumer behaviour,

\footnotetext{
${ }^{312}$ Heller, Dana. 'Before: Things Just Keep Getting Better.' In The Great American Makeover: Television, History, Nation. Ed. Dana Heller. (London: Palgrave Macmillan, 2006). Pg 1.

${ }^{313}$ Ibid. p. 1.

${ }^{314}$ Ibid. p. 4.

${ }^{315}$ Bratich, Jack. 'Programming Reality: Control Societies, New Subjects and the Powers of Transformation.' In Makeover Television: Realities Remodelled. Ed: Dana Heller. (London and New York; I.B Tauris and Co Ltd, 2007). Pg 9.

${ }^{316}$ Ibid. p. 9.

${ }^{317}$ Redden, Guy. 'Makeover Morality and Consumer Culture.' In Makeover Television: Realities Remodelled. Ed. Dana Heller. (London and New York: I.B. Tauris \& Co Ltd, 2007). Pg 151.

${ }^{318}$ Ibid. p. 154.

${ }^{319}$ Ibid. p. 158.
} 
Redden acknowledges that the behaviour of the so-called free subject is highly monitored in the school, home and shopping mall. Information found from monitoring subject behaviour can be used to create discourses designed to enrol people in activities that suit the interests of state and business, for instance to channel consumption into particular areas. ${ }^{320}$

While makeover television typically devotes a significant amount of air time to the actual process of consuming, this is not so in the teen makeover film. In makeover television, the viewer is able to watch the contestant undergo her transformation, and her thoughts are articulated as she gets her hair and makeup done and tries on various outfits to find the perfect fit for her personality. In the teen makeover film, while there may be a transformation scene in which the ugly duckling or plain Jane is turned into a swan (as in The Princess Diaries and She's All That), we are not typically privy to the protagonist's thoughts. The protagonist virtually never ventures into a shop and selects goods of her choosing, although the antagonistic characters commonly do so. Instead, she is fixed in a space, an enclosed room, where goods are brought to transform her appearance. These have been pre-selected by another character who has already envisioned exactly how he/she wants the made over girl to appear. There is not even the pretence of choice regarding the performance of femininity. The process of consuming has to be completely mediated through another body so as to ensure the protagonist does not deviate from a set path and forget that her makeover is primarily to serve the interests of another.

The girl to be made over commonly does not experience enjoyment at being transformed - there is a sense that becoming feminine is synonymous with taking medicine to cure a contagious illness, in order to cement heteronormativity, which will stabilise the romantic partnership, the nuclear family, and thus the health of society. The performance of diametrically opposed gender constructions enables desire to be channelled in an unproblematic manner in a cultural system built on

${ }^{320}$ Ibid. p. 160. 
binary opposition. The filmic space is constituted of characters whose behaviour may threaten this heterosexual desire, which is presented as instrumental to the workings of a 'healthy' nation. This natural endangered desire is vulnerable to a number of powerful forces - a key force being rampant consumerism, which threatens to corrupt the soul, presented as being what inherently makes us human, the truth of our condition.

As in makeover television, the teen makeover film does present a 'morally deserving' female candidate to be made over, reminiscent of the Cinderella fable. What constitutes being morally deserving is similar, despite the large age gap between the usual television makeover contestant and the teen makeover protagonist. The television contestant is commonly nominated by someone who knows her, and who claims the nominee never does anything for herself, being too busy looking after those around her. She is often the traditionally idealised mother figure, nurturing and unselfish, who deserves to be validated publicly. Makeover 'experts,' interestingly who may be identifiable as chick postfeminists, (for instance Trinny and Susannah on What Not To Wear), work to help restore the contestant's youth by teaching her how best to apply makeup, cut her hair in a modern style, wear clothes to slim her figure and highlight her best 'assets.'

Makeover shows make visible the idealised mother, in danger of being lost, cultivating her appearance so that she conforms to the current feminine ideal which is young, slim, perfectly made-up, disciplined and regimented in terms of keeping up appearances. The makeover show, while predicated on the supposedly charitable concept of empowering someone through improving their physical appearance, also serves to validate the made-over contestant in the eyes of their husband and children, thus stabilising the romantic partnership and family. The contestant, while having her family's best interests at heart, is in danger of putting them at risk if she fails to remember that woman is body, and this body must conform to ideals of beauty in order to remain an object of desire for her other half. 
Makeover television typically focuses on reclaiming the past of the female contestant. The transformation involves the use of products to recapture youth and vitality, which will in turn serve to make her more attractive to the opposite sex while increasing her self-confidence. Similarly, the teen makeover film links the enhancement of the female body with happiness, confidence and advancement. Instead of the focus on reclaiming the past however, there is a focus on future and destiny. The transformation is conducted with more urgency, and with more at stake, given the perceived threats to adolescence. The idea of the body as an asset in career or in wider social life is played down, with instead there being a greater emphasis on the female body as spectacle for the male eye. Elements of the recognisable makeover culture are applied to the transformation of the makeover film protagonist, but she is not encouraged to be modern and fashionable. The fashion icons here are Princesses and Queens - regal, constricted in bodily performance, constantly visible and with a role to play in a patriarchal system. This lies in contrast to the postfeminist encouragement to try on multiple modern feminine identities, even if these identities also focus on the body as spectacle. Makeover television, even if it does work to uncover the idealised mother figure, often does not question the social authority of the chick postfeminist. The makeover film identifies 'leakages' in the character of the chick postfeminist and aims to relegate her to the sidelines of makeover culture.

The recent resurgence of the makeover film nonetheless comes at a time where there is an emphasis on the cultural 'normalising' of the female body, which is placed under surveillance and taught to perform femininity more adequately. Girls and women more than ever before are taught that success lies in physical appearance, solidifying the mind/body gender binary. It is preached that the body beautiful, the performance of idealised femininity, will lead to a better life for the more 'confident' female individual. Those who do not conform to these gender norms will be condemned to a life of exclusion and ridicule - a life outside of the 'healthy workings' of society. Despite the fact that the teen makeover film appears to be now past the height of its popularity, given the continuing obsession with 
makeover television and the fact that the makeover film has been around since the 1940s, it is my prediction that it will in the future one day return. 


\section{Bibliography}

Akass Kim and McCabe Janet. 'A Perfect Lie: Visual (Dis)Pleasures and Policing Femininity in Nip/Tuck.' In Makeover Television: Realities Remodelled. London and New York: I.B Tauris \& Co Ltd, 2007. Pg 119-133.

Arthurs, Jane. 'Sex and the City and Consumer Culture: Remediating Postfeminist

Drama.' In Feminist Television Criticism: A Reader $2^{\text {nd }}$ Edition. Eds. Charlotte Brunsdon and Lynn Spiegel. Berkshire: Open University Press, McGraw-Hill Education, 2007. Pg $41-57$.

Balizet, Ariane. 'Teen Scenes: Recognizing Shakespeare in Teen Film.' Almost Shakespeare: Reinventing His Works for Cinema and Television. Eds. James R Keller and Leslie Stratyner. North Carolina: McFarland and Company, 2004. Pg 122-137.

Banet-Weiser, Sarah. 'Girls Rule! Gender, feminism and Nickelodeon,' in Feminist Television Criticism: A Reader $2^{\text {nd }}$ Edition. Eds: Charlotte Brunsdon and Lynn Spigel. Berkshire: Open University Press, McGraw-Hill Education, 2007.

Bartky, Sandra. Femininity and Domination: Studies in the Phenomenology of Oppression. New York and London: Routledge, 1990.

Bartky, Sandra. 'Foucault, Femininity and the Modernization of Patriarchal Power.' In Writing on the Body: Female Embodiment and Feminist Theory. Eds. Katie Conboy, Nadia Medina, Sarah Stanbury. New York: Columbia University Press, 1997. Pg 129-155.

Bavidge, Jenny. 'Chosen Ones: Reading the Contemporary Teen Heroine.’ In Teen TV: Genre, Consumption and Identity. Eds. Glyn Davies and Kay Dickinson. London: The British Film Institute, 2004. Pg 41-54. 
Bell, Elizabeth. 'Somatexts at the Disney Shop.' In From Mouse to Mermaid: The Politics of Film, Gender and Culture. Eds: Elizabeth Bell, Lynda Haas and Laura Sells. Bloomington and Indianapolis: Indiana University Press, 1995. Pg 107-125.

Bordo, Susan. Unbearable Weight: Feminism, Western Culture and the Body. Berkeley and Los Angeles: University of California Press, 1993.

Boyle, Karen. 'Feminism Without Men: Feminist Media Studies in a Postfeminist Age.' In Feminist Television Criticism: A Reader $2^{\text {nd }}$ Edition. Eds Charlotte Brunsdon and Lynn Spigel. Berkshire: Open University Press, McGraw-Hill Education, 2007. Pg 174-191.

Bratich, Jack. 'Programming Reality: Control Societies, New Subjects and the Powers of Transformation.' In Makeover Television: Realities Remodelled. Ed: Dana Heller. London and New York; I.B Tauris and Co Ltd, 2007. Pg 6-23.

Butler, Judith. Excitable Speech: A Politics of the Performative. London and New York: Routledge, 1997.

Butler Judith. Gender Trouble. New York, Routledge, 1990.

Butler Judith and Salih, Sara. The Judith Butler Reader. Oxford: Blackwell Publishing, 2004.

Butler, Judith. 'Performative Acts and Gender Constitution: An Essay in Phenomenology and Feminist Theory.' In Writing on the Body: Female Embodiment and Feminist Theory. Eds. Katie Conboy, Nadia Medina, and Sarah Stanbury. New York: Columbia University Press, 1997. Pg 401-419. 
Cassidy, Marsha. 'The Cinderella Makeover: Glamour Girl, Television Misery Shows and 1950s Femininity.' In The Great American Makeover: Television, History, Nation. Ed. Dana Heller. London: Palgrave Macmillan, 2006. Pg 125141.

Chacko Sarah. 'Family Breakups Costly: Promoting Healthy Marriages Touted as Remedy.' Advocate. Aug 23 2008. Pg 10.

Chisholm, Dianne. 'Climbing Like a Girl”: An Exemplary Adventure in Feminist Phenomenology.' Hypatia. Vol 23, No 1, 2008. Pg 9-40.

Christian-Smith, Linda K. 'Romancing the Girl: Adolescent Romance Novels and the Construction of Femininity.' Becoming Feminine: The Politics of Popular Culture. Eds: Leslie G Roman, Linda K Christian-Smith and Elizabeth Ellsworth. Sussex and Philadelphia: The Falmer Press, 1988. Pg 76-97.

Cowie Elizabeth. 'Woman as Sign.’ In Feminism and Film. Ed. E. Ann Kaplan. New York: Oxford University Press, 2000. Pg 48-66.

Creed, Barbara. The Monstrous-Feminine: Film, Feminism, Psychoanalysis. London: Routledge, 1993.

Davis, Glyn and Dickinson, Kay (Eds). Teen TV: Genre, Consumption and Identity. London: British Film Institute, 2004.

Doane, Mary Ann. Femmes Fatales, Film Theory, Psychoanalysis. New York and Oxon: Routledge, 1991.

Doane, Mary Ann. 'Film and the Masquerade: Theorising the Female Spectator.' In Feminism and Film. Ed. E. Ann Kaplan. Oxford and New York: Oxford University Press, 2000. Pg 418-437. 
Dyer, Richard. Stars. London: British Film Institute, 1998.

Dyer, Richard. White. Oxon and New York: Routledge, 1997.

Ford, Elizabeth and Mitchell, Deborah. The Makeover in Movies. North Carolina: McFarland and Company Inc, 2004.

Fraser, Kathryn. 'Now I am ready to tell how bodies are changed into different bodies... Ovid, The Metamorphoses.' In Makeover Television: Realities Remodelled. Ed: Dana Heller. London and New York: I.B Tauris \& Co Ltd, 2007. Pg $177-193$.

Foucault, Michel. Discipline and Punish. The Birth of the Prison. Paris: Gallimard, 1975.

Gamble, Sarah (Ed). The Routledge Companion to Feminism and Postfeminism London and New York: Routledge, 2001.

Gilbert, Sandra and Gubar, Susan. The Madwoman in the Attic: The Woman Writer and the Nineteenth Century Literary Imagination. New Haven and London: Yale University Press, 1979.

Gill, Rosalind. Gender and the Media. Cambridge: Polity Press, 2007.

Harris, Anita. Future Girl: Young Women in the Twenty First Century. New York and London: Routledge, 2004.

Haskell, Molly. From Reverence to Rape: The Treatment of Women at the Movies. $2^{\text {nd }}$ ed. Chicago and London: University of Chicago Press, 1987. 
Heller, Dana. 'Reading the Makeover.' In Makeover Television: Realities

Remodelled. London and New York: I.B. Tauris \& Co Ltd, 2007. Pg 1-6.

Hentges, Sarah. Pictures of Girlhood: Modern Female Adolescence on Film. North Carolina: McFarland and Company Inc, 2006.

Holmlund, Chris. 'Postfeminism from A to G.' Cinema Journal. 44 No 2. Winter 2005. Pg 116-120.

Hopkins, Susan. Girl Heroes: The New Force in Popular Culture. Annandale: Pluto Press, 2002.

Irwin, William and South, James B (Eds). Buffy the Vampire Slayer and Philosophy: Fear and Trembling in Sunnydale. Chicago and La Salle: Open Court Publishing Company, 2003.

James, Paula. 'She’s All That: Ovid’s Ivory Statue and the Legacy of Pygmalion on Film.’ Classical Bulletin 79.1, 2003. Pg 63-91.

Jeffords, Susan. Hard Bodies: Hollywood Masculinity in the Reagan Era. New Jersey: Rutgers University Press, 1994.

Jeffords, Susan. 'The Curse of Masculinity: Disney’s Beauty and the Beast.' In From Mouse to Mermaid: The Politics of Film, Gender and Culture. Eds: Elizabeth Bell, Lynda Haas and Laura Sells. Indiana: Indiana University Press, 1995. Pg 161-175.

Jowett, Lorna. Sex and the Slayer: A Gender Studies Primer for the Buffy Fan. Connecticut: Wesleyan University Press, 2005. 
Kaplan, E Ann. 'The Case of the Missing Mother: Maternal Issues in Vidor's Stella Dallas.' In Feminism and Film. Ed. E. Ann Kaplan. New York: Oxford University Press, 2000. Pg 466-479.

Karlyn, Kathleen Rowe. 'Too Close for Comfort: American Beauty and the Incest Motif.' Cinema Journal. 44. No 1. 2004. Pg 69-93.

Kinser, Amber. 'Negotiating Spaces For/Through Third-Wave Feminism.' NWSA V 16. 2004. Pg 124-153.

Levitan Sar, Belous Richard and Gallo Frank. What's Happening to the American Family? Baltimore and London: The John Hopkins University Press, 1988.

Levy, Ariel. Female Chauvinist Pigs: Women and the Rise of Raunch Culture. New York: Free Press, 2005.

Lloyd, Moya. Judith Butler. Cambridge: Polity Press, 2007.

McCabe, Janet. 'Lost in Transition: Problems of Modern (Heterosexual) Romance and the Catatonic Male Hero in the Postfeminist Age.' In Falling in Love Again: Romantic Comedy in Contemporary Cinema. Eds: Stacey Abbott and Deborah Jermyn. London and New York. I.B Tauris and Co Ltd, 2009. Pg 160-176.

MacKinnon, Catherine. Only Words. Cambridge: Harvard University Press, 1993.

McNay, Lois. Foucault and Feminism. Cambridge: Polity Press, 1992.

McRobbie, Angela. The Aftermath of Feminism: Gender, Culture and Social Change. London: SAGE Publications Ltd, 2009. 
Modleski, Tania. Feminism Without Women: Culture and Criticism in a 'Postfeminist' Age. New York and London: Routledge 1991.

Morgan, Kathryn Pauly. 'Women and the Knife: Cosmetic Surgery and the Colonization of Women's Bodies. In The Politics of Women's Bodies: Sexuality, Appearance and Behaviour. Ed. Rose Weitz. Oxford and New York: Oxford University Press, 2003. Pg 164-184.

Morgan, Patricia. Farewell to the Family? Public Policy and Family Breakdown in Britain and the USA. London: Institute of Economic Affairs Health and Welfare Unit, 1995.

Moseley, Rachel. 'Glamorous Witchcraft: Gender and Magic in Teen Film and Television’, Screen, 43(4), 2002.

Moseley, Rachel. Growing Up With Audrey Hepburn. Manchester and New York: Manchester University Press, 2002.

Mulvey, Laura. 'Visual Pleasure and Narrative Cinema.' In Feminism and Film. Ed. E Ann Kaplan. Oxford and New York: Oxford University Press, 2000.

Munford, Rebecca. 'Wake Up and Smell the Lipgloss: Gender, Generation and the (A)Politics of Girl Power.' In Third Wave Feminism: A Critical Exploration. Eds. Stacy Gillis, Gillian Howie, Rebecca Munford. New York: Palgrave MacMillan, 2007. Pg 266-277.

Negra, Diane. What a Girl Wants? Fantasizing the Reclamation of Self in Postfeminism. London and New York: Routledge, 2009.

Negra, Diane and Tasker, Yvonne. Interrogating Postfeminism: Gender and the Politics of Popular Culture. USA: Duke University Press, 2007. 
Pipher, Mary. Reviving Ophelia: Saving the Selves of Adolescent Girls. New York: Ballantine Books: Random House Publishing Group, 1994.

Place, Janey. 'Women in Film Noir.' Women in Film Noir. Ed: E. Ann Kaplan. London: British Film Institute, 1998.

Projansky, Sarah. 'Mass Magazne Cover Girls: Some Reflections on Postfeminist Girls and Postfeminism’s Daughters.' In Interrogating Postfeminism: Gender and the Politics of Popular Culture. Eds. Diane Negra and Yvonne Tasker. Durham and London: Duke University Press, 2007. Pg 40-70.

Radner, Hilary. Shopping Around: Feminine Culture and the Pursuit of Pleasure. New York and London: Routledge, 1995.

Redden, Guy. 'Makeover Morality and Consumer Culture.’ In Makeover Television: Realities Remodelled. Ed. Dana Heller. London and New York: I.B. Tauris \& Co Ltd, 2007. Pg 150-165.

Smith, Donna. Stepmothering. Hertfordshire: Harvester Wheatsheaf, 1990.

Sobchack Vivian. Carnal Thoughts: Embodiment and Moving Image Culture. Berkeley and Los Angeles: University of California Press, 2004.

Spelman, Elizabeth V. 'Woman as Body.' Feminist Theory and the Body. Eds. Janet Price and Margrit Shildrick. New York: Routledge, 1999. Pg 32-42.

Stacey, Jackie. Star Gazing: Hollywood Cinema and Female Spectatorship. New York and London: Routledge, 1994. 
Studlar, Gaylyn. 'Masochism and the Perverse Pleasures of the Cinema.' In

Feminism and Film. Ed. E. Ann Kaplan. Oxford and New York: Oxford

University Press, 2000. Pg 203-226.

Sweeney, Kathleen. Maiden USA: Girl Icons Come of Age. New York: Peter Lang Publishing, 2008.

Taft, Jessica K. 'Girl Power Politics: Pop Culture Barriers and Organizational Resistance.' All About the Girl: Culture, Power and Identity. Ed: Anita Harris. New York and Oxon: Routledge, 2004.

Tasker, Yvonne. Working Girls: Gender and Sexuality in Popular Culture. London: Routledge, 1988.

Valenti, Jessica. The Purity Myth: How America's Obsession with Virginity Is Hurting Young Women. California: Seal Press, 2009.

Walkerdine, Valerie. Daddy's Girl: Young Girls and Popular Culture. Massachusetts: Harvard University Press, 1997.

Warner, Marina. From the Beast to the Blonde: On Fairy Tales and Their Tellers. London: Chatto \& Windus, 1994.

Wartenberg, Thomas E. Unlikely Couples: Movie Romance as Social Criticism, Colorado: Westview Press, 1999.

Watson, Patricia A. Ancient Stepmothers: Myth, Misogyny and Reality. Leiden: E.J Brill, 1995. 
Weitz, Rose. 'A History of Women’s Bodies.' In The Politics of Women's Bodies; Sexuality, Appearance and Behaviour. Ed. Rose Weitz. Oxford and New York: Oxford University Press, 2003. Pg 3-12.

Whelehan, Imelda. Modern Feminist Thought: From the Second Wave to 'PostFeminism.’ Edinburgh: Edinburgh University Press, 1995.

Wooten, Jim. 'Put Families First, One Father at a Time.’ The Atlanta Journal. April 21, 2009. Pg 8.

Young, Iris Marion. On Female Body Experience: Throwing Like a Girl and Other Essays. New York: Oxford University Press, 1995.

Zipes, Jack. 'Breaking the Disney Spell.’ In From Mouse to Mermaid: The Politics of Film, Gender and Culture. Eds: Elizabeth Bell, Lynda Haas and Laura Sells. Bloomington and Indianapolis: Indiana University Press, 1995. Pg 21-43.

Zipes, Jack. When Dreams Come True: Classical Fairy Tales and their Tradition. New York and London: Routledge, 1999. 


\section{Filmography}

Caro, Niki, dir. North Country. Warner Bros Pictures, USA, 2005.

Cassavetes, Nick, dir. The Notebook. New Line Cinema, USA, 2004.

Geronimi, Clyde and Jackson, Wilfred. Cinderella. Walt Disney Pictures, USA, 1950.

Gosnell, Raja, dir. Never Been Kissed. Fox 2000 Pictures, USA, 1999.

Heckerling, Amy, dir. Clueless. Paramount Pictures, USA, 1995.

Huston, John, dir. Annie. Columbia Pictures, USA, 1982.

Iscove, Robert, dir. She’s All That. Miramax International, USA, 1999.

Junger, Gil, dir. 10 Things I Hate About You. Touchstone Pictures, USA, 1999.

Maguire, Sharon, dir. Bridget Jones’s Diary. Universal Pictures and Miramax, UK and USA, 2001.

Marshall, Garry, dir. Pretty Woman. Touchstone Pictures, USA, 1990.

Marshall, Garry, dir. The Princess Diaries. Walt Disney Pictures, USA, 2001.

McG, dir. Charlie’s Angels. Columbia Pictures, USA, 2000.

Moore, Nick, dir. Wild Child. Universal Pictures, USA, 2008.

Nichols, Mike, dir. Working Girl. 20 ${ }^{\text {th }}$ Century Fox Film Corporation, USA, 1988. 
Petrie, Donald, dir. How to Lose a Guy in 10 Days. Paramount Pictures, USA, 2003.

Rapper, Irving, dir. Now, Voyager. Warner Bros Pictures, USA, 1942.

Ritchie, Guy, dir. Sherlock Holmes. Warner Bros Pictures, USA, 2009.

Rosman, Mark, dir. A Cinderella Story. Warners Bros Pictures, USA, 2004.

Soderbergh, Steven, dir. Erin Brockovich. Universal Pictures, USA, 2000.

Trousdale, Gary and Wise, Kirk. Beauty and the Beast. Walt Disney Pictures, USA, 1991.

Von Sternberg, Josef, dir. Morocco. Paramount Pictures, USA, 1930.

Waters, Mark, dir. Mean Girls. Paramount Pictures, USA, 2004. 


\section{$\underline{\text { Television Sources }}$}

10 Years Younger. (2004 - , UK: Channel 4).

Ally McBeal. (1997-2002, USA: 20 ${ }^{\text {th }}$ Century Fox Television).

America’s Got Talent. (2006 - , USA: NBC).

American Idol. (2002 - , USA: 20 ${ }^{\text {th }}$ Century Fox Television).

America's Next Top Model. (2003 - , USA: The CW).

Buffy the Vampire Slayer. (1997-2003, USA: Warner Bros Television Network).

Charmed. (1998-2006, USA: Warner Bros Television Network).

Dark Angel, (2000-2002, USA: $20^{\text {th }}$ Century Fox Television).

Desperate Housewives. (2004 - , USA: ABC Studios).

Dr 90210. (2004 - , USA: E! Entertainment Television).

Dr Phil. (2002 - , USA: Harpo Productions).

Extreme Makeover. (2002-2005, USA: ABC Studios).

Gok’s Fashion Fix. (2008, UK: Channel 4).

Gossip Girl. (2007 - , USA: The CW).

Hannah Montana, (2006 - , USA: Walt Disney Studios). 
Lipstick Jungle. (2008-2009, USA: NBC).

Lizzie McGuire. (2001-2004, USA: Walt Disney Studios).

The O.C. (2003-2007, USA: Fox Television).

Pop Idol. (2001-2003, UK, ITV Productions).

The Powerpuff Girls. (1998-2004, USA: Hanna Barbera and Cartoon Network Studios).

Queer Eye for the Straight Guy. (2003 - , USA, NBC).

Sex and the City. (1998-2004, USA: HBO).

The Swan, (2004-2005, USA: $20^{\text {th }}$ Century Fox Television).

Trinny and Susannah Undress the Nation. (2007 - , UK: ITV Productions).

What Not To Wear. (2001-2007, UK: BBC). 


\section{Internet Sources}

New York Daily News

http://www.nydailynews.com/gossip/2008/04/28/2008-04

28 disney_miley_cyrus_blast_vanity_fair_mag.html (accessed 27/07/2010). 
